Cochrane Database of Systematic Reviews

\title{
Different antibiotic treatments for group A streptococcal pharyngitis (Review)
}

van Driel ML, De Sutter AIM, Habraken H, Thorning S, Christiaens T

van Driel ML, De Sutter AIM, Habraken H, Thorning S, Christiaens T.

Different antibiotic treatments for group A streptococcal pharyngitis.

Cochrane Database of Systematic Reviews 2016, Issue 9. Art. No.: CD004406.

DOI: 10.1002/14651858.CD004406.pub4.

www.cochranelibrary.com 
TABLE OF CONTENTS

HEADER

ABSTRACT

PLAIN LANGUAGE SUMMARY

SUMMARY OF FINDINGS

2

BACKGROUND

OBJECTIVES

METHODS

Figure 1.

RESULTS

Figure 2.

Figure 3.

DISCUSSION

AUTHORS' CONCLUSIONS

ACKNOWLEDGEMENTS

REFERENCES

CHARACTERISTICS OF STUDIES

DATA AND ANALYSES

Analysis 1.1. Comparison 1 Cephalosporin versus penicillin, Outcome 1 Resolution of symptoms post-treatment (ITT analysis).

Analysis 1.2. Comparison 1 Cephalosporin versus penicillin, Outcome 2 Resolution of symptoms post-treatment (evaluable participants).

Analysis 1.3. Comparison 1 Cephalosporin versus penicillin, Outcome 3 Resolution of symptoms within 24 hours of treatment (ITT analysis).

Analysis 1.4. Comparison 1 Cephalosporin versus penicillin, Outcome 4 Sore throat (ITT analysis).

Analysis 1.5. Comparison 1 Cephalosporin versus penicillin, Outcome 5 Fever (ITT analysis).

Analysis 1.6. Comparison 1 Cephalosporin versus penicillin, Outcome 6 Incidence of relapse (evaluable participants). ...........

Analysis 1.7. Comparison 1 Cephalosporin versus penicillin, Outcome 7 Complications (ITT analysis).

Analysis 1.8. Comparison 1 Cephalosporin versus penicillin, Outcome 8 Adverse events (ITT analysis).

Analysis 1.9. Comparison 1 Cephalosporin versus penicillin, Outcome 9 Resolution of symptoms ITT (subgroup sponsored versus no sponsor reported).

Analysis 2.1. Comparison 2 Macrolide versus penicillin, Outcome 1 Resolution of symptoms post-treatment (ITT analysis). .... Analysis 2.2. Comparison 2 Macrolide versus penicillin, Outcome 2 Resolution of symptoms post-treatment (evaluable participants only).

Analysis 2.3. Comparison 2 Macrolide versus penicillin, Outcome 3 Sore throat post-treatment (ITT analysis).

Analysis 2.4. Comparison 2 Macrolide versus penicillin, Outcome 4 Fever post-treatment (ITT analysis).

Analysis 2.5. Comparison 2 Macrolide versus penicillin, Outcome 5 Incidence of relapse (evaluable participants).

Analysis 2.6. Comparison 2 Macrolide versus penicillin, Outcome 6 Adverse events (ITT analysis).

Analysis 2.7. Comparison 2 Macrolide versus penicillin, Outcome 7 Resolution of symptoms ITT (subgroup sponsored versus no sponsor reported).

Analysis 3.1. Comparison 3 Azithromycin versus amoxicillin, Outcome 1 Clinical cure at 24-28 days (ITT).

Analysis 3.2. Comparison 3 Azithromycin versus amoxicillin, Outcome 2 Clinical cure at 24-28 days (bacteriological per protocol population).

Analysis 3.3. Comparison 3 Azithromycin versus amoxicillin, Outcome 3 Relapse on day 38-45 (ITT).

Analysis 3.4. Comparison 3 Azithromycin versus amoxicillin, Outcome 4 Relapse on day 38-45 (bacteriological per protocol). ..

Analysis 3.5. Comparison 3 Azithromycin versus amoxicillin, Outcome 5 Adverse events (all patients).

Analysis 4.1. Comparison 4 Carbacephem versus penicillin, Outcome 1 Resolution of symptoms post-treatment (ITT analysis).

Analysis 4.2. Comparison 4 Carbacephem versus penicillin, Outcome 2 Resolution of symptoms post-treatment (evaluable participants).

Analysis 4.3. Comparison 4 Carbacephem versus penicillin, Outcome 3 Incidence of relapse (evaluable participants). ............

Analysis 4.4. Comparison 4 Carbacephem versus penicillin, Outcome 4 Adverse events (ITT analysis).

Analysis 5.1. Comparison 5 Clindamycin versus ampicillin, Outcome 1 Adverse events (ITT analysis). 
[Intervention Review]

\section{Different antibiotic treatments for group A streptococcal pharyngitis}

Mieke L van Driel1,2,3, An IM De Sutter ${ }^{3}$, Hilde Habraken ${ }^{4}$, Sarah Thorning ${ }^{5}$, Thierry Christiaens ${ }^{6}$

1Discipline of General Practice, School of Medicine, The University of Queensland, Brisbane, Australia. ${ }^{2}$ Centre for Research in EvidenceBased Practice (CREBP), Bond University, Gold Coast, Australia. ${ }^{3}$ Department of Family Medicine and Primary Health Care, Ghent University, Ghent, Belgium. ${ }^{4}$ Farmaka, Ghent, Belgium. ${ }^{5}$ GCUH Library, Gold Coast University Hospital, Southport, Australia. 6 Heymans Institute of Pharmacology, Ghent University, Ghent, Belgium

Contact address: Mieke L van Driel, Discipline of General Practice, School of Medicine, The University of Queensland, Brisbane, Queensland, 4029, Australia.m.vandriel@uq.edu.au, mieke.vandriel@ugent.be.

Editorial group: Cochrane Acute Respiratory Infections Group.

Publication status and date: New search for studies and content updated (no change to conclusions), published in Issue 9, 2016.

Citation: van Driel ML, De Sutter AIM, Habraken H, Thorning S, Christiaens T. Different antibiotic treatments for group A streptococcal pharyngitis. Cochrane Database of Systematic Reviews 2016, Issue 9. Art. No.: CD004406. DOI: 10.1002/14651858.CD004406.pub4.

Copyright @ 2016 The Cochrane Collaboration. Published by John Wiley \& Sons, Ltd.

\section{A B S T R A C T}

\section{Background}

Antibiotics provide only modest benefit in treating sore throat, although effectiveness increases in participants with positive throat swabs for group A beta-haemolytic streptococci (GABHS). It is unclear which antibiotic is the best choice if antibiotics are indicated.

\section{Objectives}

To assess the evidence on the comparative efficacy of different antibiotics in: (a) alleviating symptoms (pain, fever); (b) shortening the duration of the illness; (c) preventing relapse; and (d) preventing complications (suppurative complications, acute rheumatic fever, poststreptococcal glomerulonephritis). To assess the evidence on the comparative incidence of adverse effects and the risk-benefit of antibiotic treatment for streptococcal pharyngitis.

\section{Search methods}

We searched CENTRAL (2016, Issue 3), MEDLINE Ovid (1946 to March week 3, 2016), Embase Elsevier (1974 to March 2016), and Web of Science Thomson Reuters (2010 to March 2016). We also searched clinical trials registers.

\section{Selection criteria}

Randomised, double-blind trials comparing different antibiotics and reporting at least one of the following: clinical cure, clinical relapse, or complications or adverse events, or both.

\section{Data collection and analysis}

Two review authors independently screened trials for inclusion, and extracted data using standard methodological procedures as recommended by Cochrane. We assessed risk of bias of included studies according to the methods outlined in the Cochrane Handbook for Systematic Reviews of Interventions and used the GRADE tool to assess the overall quality of evidence for the outcomes.

\section{Main results}

We included 19 trials (5839 randomised participants); seven compared penicillin with cephalosporins, six compared penicillin with macrolides, three compared penicillin with carbacephem, one trial compared penicillin with sulphonamides, one trial compared clindamycin with ampicillin, and one trial compared azithromycin with amoxicillin in children. All included trials reported clinical outcomes. Reporting of randomisation, allocation concealment, and blinding was poor in all trials. The overall quality of the evidence assessed using the GRADE tool was low for the outcome 'resolution of symptoms' in the intention-to-treat (ITT) analysis and very low for 
the outcomes 'resolution of symptoms' of evaluable participants and for adverse events. We downgraded the quality of evidence mainly due to lack of (or poor reporting of) randomisation or blinding, or both, heterogeneity, and wide confidence intervals (Cls).

There was a difference in symptom resolution in favour of cephalosporins compared with penicillin (evaluable patients analysis odds ratio (OR) for absence of resolution of symptoms $0.51,95 \% \mathrm{Cl} 0.27$ to 0.97 ; number needed to treat to benefit (NNTB) $20, N=5, n=1660 ;$ very low quality evidence). However, this was not statistically significant in the ITT analysis (OR 0.79, $95 \% \mathrm{Cl} 0.55$ to $1.12 ; \mathrm{N}=5, \mathrm{n}=2018 ;$ low quality evidence). Clinical relapse was lower for cephalosporins compared with penicillin (OR $0.55,95 \% \mathrm{Cl} 0.30$ to $0.99 ; \mathrm{NNTB} 50, \mathrm{~N}=4, \mathrm{n}=1386$; low quality evidence), but this was found only in adults (OR $0.42,95 \% \mathrm{Cl} 0.20$ to 0.88 ; NNTB 33, $\mathrm{N}=2, \mathrm{n}=770$ ). There were no differences between macrolides and penicillin for any of the outcomes. One unpublished trial in children found a better cure rate for azithromycin in a single dose compared to amoxicillin for 10 days (OR $0.29,95 \% \mathrm{Cl} 0.11$ to 0.73 ; NNTB $18, \mathrm{~N}=1, \mathrm{n}=482$ ), but there was no difference between the groups in ITT analysis (OR $0.76,95 \% \mathrm{Cl} 0.55$ to $1.05 ; \mathrm{N}=1, \mathrm{n}=673$ ) or at long-term follow-up (evaluable patients analysis OR $0.88,95 \%$ $\mathrm{Cl} 0.43$ to $1.82 ; \mathrm{N}=1, \mathrm{n}=422)$. Children experienced more adverse events with azithromycin compared to amoxicillin $(\mathrm{OR} 2.67,95 \% \mathrm{Cl} 1.78$ to 3.99; $N=1, n=673$ ). Compared with penicillin carbacephem showed better symptom resolution post-treatment in adults and children combined (ITT analysis OR $0.70,95 \% \mathrm{Cl} 0.49$ to 0.99 ; NNTB $14, \mathrm{~N}=3, \mathrm{n}=795)$, and in the subgroup analysis of children $(\mathrm{OR} 0.57,95 \% \mathrm{Cl} 0.33$ to 0.99 ; NNTB $8, \mathrm{~N}=1, \mathrm{n}=233$ ), but not in the subgroup analysis of adults (OR $0.75,95 \% \mathrm{Cl} 0.46$ to $1.22, \mathrm{~N}=2, \mathrm{n}=562$ ). Children experienced more adverse events with macrolides compared with penicillin (OR 2.33, 95\% $\mathrm{Cl} 1.06$ to $5.15 ; \mathrm{N}=1, \mathrm{n}=489$ ). Studies did not report on longterm complications so it was unclear if any class of antibiotics was better in preventing serious but rare complications.

\section{Authors' conclusions}

There were no clinically relevant differences in symptom resolution when comparing cephalosporins and macrolides with penicillin in the treatment of GABHS tonsillopharyngitis. Limited evidence in adults suggests cephalosporins are more effective than penicillin for relapse, but the NNTB is high. Limited evidence in children suggests carbacephem is more effective than penicillin for symptom resolution. Data on complications are too scarce to draw conclusions. Based on these results and considering the low cost and absence of resistance, penicillin can still be regarded as a first choice treatment for both adults and children. All studies were in high-income countries with low risk of streptococcal complications, so there is need for trials in low-income countries and Aboriginal communities where risk of complications remains high.

\section{PLAIN LANGUAGE SUMMARY}

\section{Different antibiotics for group A streptococcal pharyngitis}

\section{Review question}

We wanted to know which antibiotic was more effective in treating sore throats caused by bacteria (group A beta-haemolytic streptococci (GABHS)).

\section{Background}

Most sore throats are caused by viruses, but many people carry throat bacteria, sometimes causing bacterial throat infection.

GABHS infection can have serious complications including rheumatic fever and kidney disease. Antibiotics are often prescribed to prevent complications, but provide modest benefit for sore throat, even if GABHS are present. Most throat infections are self-limiting and complication risks is extremely low for most people in high-income countries. However, sometimes antibiotics are needed. Penicillin, a cheap antibiotic, has been used to treat GABHS for many years. GABHS resistance to penicillin is rare.

\section{Search date}

We searched the literature to March 2016.

\section{Study characteristics}

We included 19 trials (18 publications) that involved 5835 people. Trials studied different antibiotics for people with sore throat who tested positive for GABHS, and were aged from one month to 80 years. Nine trials included only children; and nine included people aged 12 years or older. Most studies were published over 15 years ago; all but one reported on clinical outcomes.

\section{Study funding sources}

Thirteen trials were supported by drug study funding - some received grants - others included people employed by drug companies. Five studies did not report funding.

\section{Key results}

Antibiotic effects were similar, and all caused side effects (such as nausea and vomiting, rash), but there was no strong evidence to show meaningful differences between antibiotics. Studies did not report on long-term complications so it was unclear if any class of antibiotics was better in preventing serious but rare complications. 
All studies were in high-income countries with low risk of streptococcal complications, so there is a need for trials in low-income countries and Aboriginal communities where risk remains high. Our review supports the use of penicillin as a first choice antibiotic in patients with throat infections caused by GABHS.

\section{Quality of the evidence}

Evidence quality was low or very low for all outcomes when macrolides or cephalosporins were compared with penicillin. Evidence quality was downgraded because of concerns about randomisation and blinding, wide confidence intervals (estimates were not very precise) and statistical differences among studies that may impact on the validity of the estimate. Most study authors did not report enough information about methods to be sure there was no bias. 


\begin{tabular}{|c|c|c|c|c|c|c|c|}
\hline \multirow{9}{*}{ 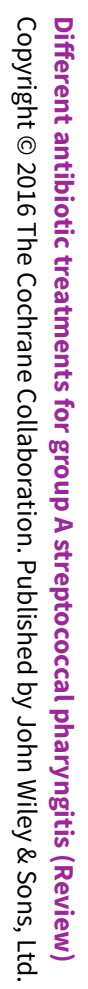 } & \multicolumn{7}{|c|}{$\begin{array}{l}\text { S U M M A R Y O F F I N D I N G S } \\
\text { Summary of findings for the main comparison. Cephalosporins compared to } p\end{array}$} \\
\hline & \multicolumn{7}{|c|}{ Cephalosporins compared to penicillin for group A streptococcal pharyngitis } \\
\hline & \multicolumn{7}{|c|}{$\begin{array}{l}\text { Patient or population: group A streptococcal pharyngitis } \\
\text { Setting: outpatients } \\
\text { Intervention: cephalosporin } \\
\text { Comparison: penicillin }\end{array}$} \\
\hline & \multirow[t]{2}{*}{ Outcomes } & \multicolumn{2}{|c|}{ Anticipated absolute effects ${ }^{\star}(95 \% \mathrm{Cl})$} & \multirow{2}{*}{$\begin{array}{l}\text { Relative effect } \\
(95 \% \mathrm{Cl})\end{array}$} & \multirow{2}{*}{$\begin{array}{l}\text { No of partici- } \\
\text { pants } \\
\text { (studies) }\end{array}$} & \multirow{2}{*}{$\begin{array}{l}\text { Quality of the } \\
\text { evidence } \\
\text { (GRADE) }\end{array}$} & \multirow[t]{2}{*}{ Comments } \\
\hline & & Risk with penicillin & Risk with Cephalosporin & & & & \\
\hline & \multirow{2}{*}{$\begin{array}{l}\text { Resolution of symptoms } \\
\text { post-treatment (ITT analy- } \\
\text { sis) }\end{array}$} & Study population & & \multirow{2}{*}{$\begin{array}{l}\text { OR } 0.79 \\
\text { (0.55 to } 1.12)\end{array}$} & \multirow{2}{*}{$\begin{array}{l}2018 \\
\text { (5 RCTs) }\end{array}$} & \multirow{2}{*}{$\begin{array}{l}\oplus \oplus \odot \ominus \\
\text { LOW } 12\end{array}$} & \\
\hline & & 245 per 1,000 & $\begin{array}{l}204 \text { per } 1,000 \\
\text { (151 to } 267)\end{array}$ & & & & \\
\hline & \multirow{2}{*}{$\begin{array}{l}\text { Resolution of symptoms } \\
\text { post-treatment (ITT analy- } \\
\text { sis) - Adults }\end{array}$} & \multicolumn{2}{|l|}{ Study population } & \multirow{2}{*}{$\begin{array}{l}\text { OR } 0.78 \\
\text { (0.60 to } 1.01)\end{array}$} & \multirow{2}{*}{$\begin{array}{l}1163 \\
(2 \mathrm{RCTs})\end{array}$} & \multirow{2}{*}{$\begin{array}{l}\oplus \oplus \ominus \ominus \\
\text { LOW } 12\end{array}$} & \\
\hline & & 320 per 1,000 & $\begin{array}{l}268 \text { per } 1,000 \\
\text { (220 to } 322)\end{array}$ & & & & \\
\hline & \multirow{2}{*}{$\begin{array}{l}\text { Resolution of symptoms } \\
\text { post-treatment (ITT analy- } \\
\text { sis) - Children }\end{array}$} & \multicolumn{2}{|l|}{ Study population } & \multirow{2}{*}{$\begin{array}{l}\text { OR } 0.83 \\
\text { (0.40 to } 1.73 \text { ) }\end{array}$} & \multirow{2}{*}{$\begin{array}{l}855 \\
(3 \mathrm{RCTs})\end{array}$} & \multirow{2}{*}{$\begin{array}{l}\oplus \ominus \ominus \ominus \\
\text { VERY LOW } 123\end{array}$} & \\
\hline & & 167 per 1,000 & $\begin{array}{l}143 \text { per } 1,000 \\
\text { (74 to } 258)\end{array}$ & & & & \\
\hline & \multirow{2}{*}{$\begin{array}{l}\text { Resolution of symptoms } \\
\text { post-treatment (evaluable } \\
\text { participants) }\end{array}$} & \multicolumn{2}{|l|}{ Study population } & \multirow{2}{*}{$\begin{array}{l}\text { OR } 0.51 \\
\text { (0.27 to } 0.97)\end{array}$} & \multirow{2}{*}{$\begin{array}{l}1660 \\
\text { (5 RCTs) }\end{array}$} & \multirow{2}{*}{$\begin{array}{l}\oplus \ominus \ominus \ominus \\
\text { VERY LOW } 123\end{array}$} & \\
\hline & & 112 per 1,000 & $\begin{array}{l}60 \text { per } 1,000 \\
\text { (33 to } 109)\end{array}$ & & & & \\
\hline & \multirow{2}{*}{$\begin{array}{l}\text { Incidence of relapse (evalu- } \\
\text { able participants) }\end{array}$} & \multicolumn{2}{|l|}{ Study population } & \multirow{2}{*}{$\begin{array}{l}\text { OR } 0.55 \\
\text { (0.30 to } 0.99)\end{array}$} & \multirow{2}{*}{$\begin{array}{l}1386 \\
\text { (4 RCTs) }\end{array}$} & \multirow{2}{*}{$\begin{array}{l}\oplus \oplus \Theta \odot \\
\text { LOW } 12\end{array}$} & \\
\hline & & 46 per 1,000 & $\begin{array}{l}26 \text { per } 1,000 \\
(14 \text { to } 45)\end{array}$ & & & & \\
\hline & \multirow{2}{*}{$\begin{array}{l}\text { Adverse events (ITT analy- } \\
\text { sis) }\end{array}$} & Study population & & \multirow{2}{*}{$\begin{array}{l}\text { OR } 0.94 \\
(0.27 \text { to } 3.25)\end{array}$} & \multirow{2}{*}{$\begin{array}{l}1279 \\
\text { (3 RCTs) }\end{array}$} & $\oplus \ominus \ominus \ominus$ & \\
\hline & & 193 per 1,000 & 184 per 1,000 & & & & \\
\hline
\end{tabular}




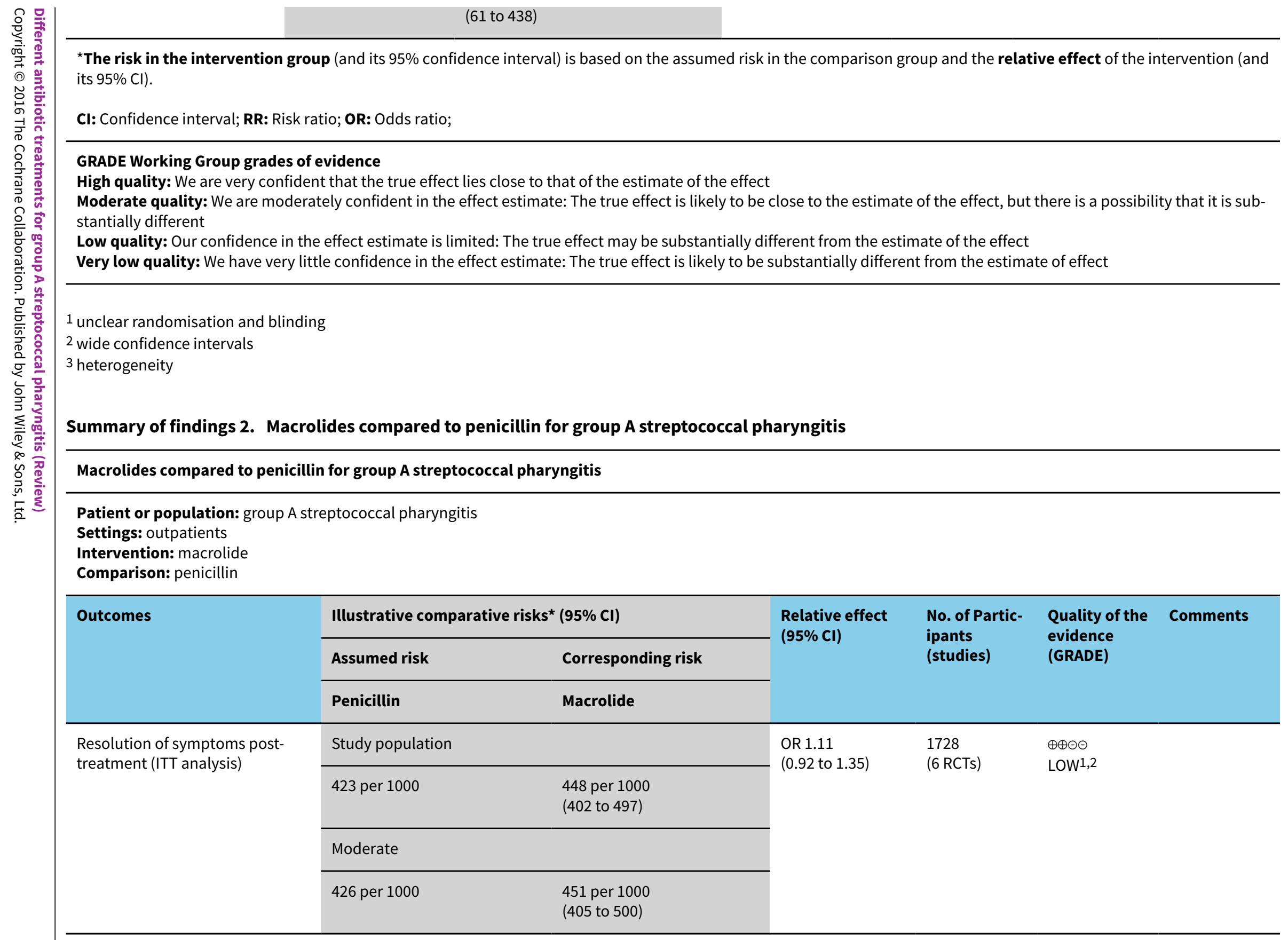




\begin{tabular}{|c|c|c|c|c|c|}
\hline \multirow{4}{*}{ 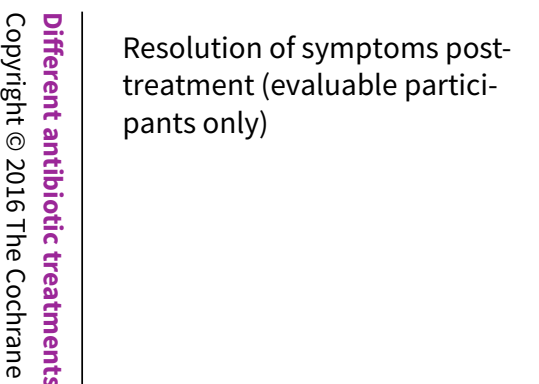 } & \multicolumn{2}{|c|}{ Study population } & \multirow{4}{*}{$\begin{array}{l}\text { OR } 0.79 \\
\text { (0.57 to } 1.09)\end{array}$} & \multirow{4}{*}{$\begin{array}{l}1159 \\
(6 \mathrm{RCTs})\end{array}$} & \multirow{4}{*}{$\begin{array}{l}\oplus \oplus \oplus \ominus \\
\text { LOW } 1,2\end{array}$} \\
\hline & 172 per 1000 & $\begin{array}{l}141 \text { per } 1000 \\
(106 \text { to } 185)\end{array}$ & & & \\
\hline & \multicolumn{2}{|l|}{ Moderate } & & & \\
\hline & 161 per 1000 & $\begin{array}{l}131 \text { per } 1000 \\
\text { (98 to } 173)\end{array}$ & & & \\
\hline \multirow{4}{*}{$\begin{array}{l}\text { Incidence of relapse (evaluable } \\
\text { participants) }\end{array}$} & \multicolumn{2}{|c|}{ Study population } & \multirow{4}{*}{$\begin{array}{l}\text { OR } 1.21 \\
\text { (0.48 to } 3.03 \text { ) }\end{array}$} & \multirow{4}{*}{$\begin{array}{l}802 \\
\text { (6 RCTs) }\end{array}$} & \multirow{4}{*}{$\begin{array}{l}\oplus \oplus \ominus \ominus \\
\text { LOW } 1,2\end{array}$} \\
\hline & 44 per 1000 & $\begin{array}{l}53 \text { per } 1000 \\
(22 \text { to } 123)\end{array}$ & & & \\
\hline & \multicolumn{2}{|l|}{ Moderate } & & & \\
\hline & 109 per 1000 & $\begin{array}{l}129 \text { per } 1000 \\
(56 \text { to } 271)\end{array}$ & & & \\
\hline \multirow[t]{4}{*}{ Adverse events (ITT analysis) } & \multicolumn{2}{|c|}{ Study population } & \multirow{4}{*}{$\begin{array}{l}\text { OR } 1.19 \\
\text { (0.82 to } 1.73)\end{array}$} & \multirow{4}{*}{$\begin{array}{l}1727 \\
\text { (6 RCTs) }\end{array}$} & \multirow{4}{*}{$\begin{array}{l}\oplus \oplus \oplus \ominus \\
\text { LOW } 1,2\end{array}$} \\
\hline & 324 per 1000 & $\begin{array}{l}363 \text { per } 1000 \\
\text { (282 to } 453)\end{array}$ & & & \\
\hline & \multicolumn{2}{|l|}{ Moderate } & & & \\
\hline & 286 per 1000 & $\begin{array}{l}323 \text { per } 1000 \\
(248 \text { to } 410)\end{array}$ & & & \\
\hline
\end{tabular}

${ }^{\star}$ The basis for the assumed risk (e.g. the median control group risk across studies) is provided in footnotes. The corresponding risk (and its $95 \%$ confidence interval) is based on the assumed risk in the comparison group and the relative effect of the intervention (and its $95 \% \mathrm{Cl}$ ).

CI: confidence interval; ITT: intention-to-treat; OR: odds ratio; $\mathbf{R C T}$ : randomised controlled trial.

GRADE Working Group grades of evidence

High quality: Further research is very unlikely to change our confidence in the estimate of effect.

Moderate quality: Further research is likely to have an important impact on our confidence in the estimate of effect and may change the estimate.

Low quality: Further research is very likely to have an important impact on our confidence in the estimate of effect and is likely to change the estimate.

Very low quality: We are very uncertain about the estimate.

1Unclear randomisation.

2Wide confidence intervals. 


\section{B A C K G R O U N D}

\section{Description of the condition}

Pharyngitis is a common upper respiratory tract infection. Antibiotics are often prescribed to treat this condition. Patients usually consult a physician with the complaint of sore throat. A previous Cochrane review comparing the effect of antibiotics to placebo in participants with or without GABHS sore throat pointed to the self-limiting nature of an acute sore throat (even in cases of positive GABHS culture) (Spinks 2013). Antibiotics provide only modest benefit when prescribed for sore throat. The effect of antibiotic treatment was increased in participants with positive throat swabs for GABHS. The streptococci-positive participants are only a small proportion of all participants with sore throat. Nevertheless, in many countries antibiotics are prescribed for most people who have a sore throat (Cars 2001; Linder 2001). Given the high consumption of antibiotics for this condition, a rational approach would be to reserve treatment with antibiotics for participants with proven presence, or a high likelihood of GABHS (Cooper 2001; Snow 2001). However, clinical scoring systems are somewhat limited in their ability to correctly target GABHS-positive patients (Mclsaac 1998), and the usefulness of rapid assay tests depends on the prevalence of GABHS in the population (Sonnad 1999); justification of its cost-effectiveness is unclear (Gerber 2004; Neuner 2003).

\section{Description of the intervention}

The slight benefit of treatment with antibiotics in patients with GABHS sore throat may be considered relevant. When antibiotics are indicated, a choice needs to be made. In that case, several aspects need to be considered, such as the comparative benefitharm balance, costs, and local antimicrobial resistance patterns. Many guidelines recommend penicillin as a first choice, with erythromycin preferred for people who are allergic to penicillin (Cooper 2001; Snow 2001). To date, resistance of GABHS to penicillin has only been documented incidentally (Devi 2011; Gerber 2009b; Ibrahim 2014), and resistance to erythromycin is still low (Cooper 2001). Considering the growing problem of antibiotic resistance for other pathogens, this responsiveness of GABHS should not be endangered (Wise 1998). Penicillin and erythromycin are cheap and the most cost-effective option. Despite this, physicians continue to prescribe broad-spectrum antibiotics, including recently marketed ones. It is not clear if these antibiotics have any substantial clinical benefit over penicillin (and erythromycin).

\section{Why it is important to do this review}

Internationally, guidelines recommend using penicillin as first choice when choosing to treat people with acute sore throat (suspected to be caused by GABHS) with antibiotics (Matthys 2007). However, some argue that cephalosporins are more effective and should therefore be preferred (Casey 2004). Many physicians argue that occurrence of penicillin allergy should be taken into account when making a choice for an antibiotic. This review looked for evidence of penicillin allergy occurring in the available trials. In addition, in the presence of documented penicillin allergy, the side effect profile of eligible antibiotics can guide choice. Therefore, to provide healthcare providers with sufficient information to make an evidence-based choice, both treatment benefits and adverse events are compared.

\section{O B JECTIVES}

To assess the evidence on the comparative efficacy of different antibiotics in: (a) alleviating symptoms (pain, fever); (b) shortening the duration of the illness; (c) preventing relapse; and (d) preventing complications (suppurative complications, acute rheumatic fever, post-streptococcal glomerulonephritis). To assess the evidence on the comparative incidence of adverse effects and the risk-benefit of antibiotic treatment for streptococcal pharyngitis.

\section{METHODS}

\section{Criteria for considering studies for this review}

\section{Types of studies}

Randomised, double-blind, controlled trials comparing at least two different classes of antibiotics.

\section{Types of participants}

Adults and children of all ages presenting with symptoms of sore throat and with an infection caused by GABHS confirmed by a throat culture, rapid test or both.

\section{Types of interventions}

Antibiotics of one class compared with another class.

\section{Types of outcome measures}

The focus was on outcome measures relevant for patients.

\section{Primary outcomes}

1. Resolution of symptoms (cure or improvement of signs and symptoms, which could include sore throat, fever, feeling ill, etc.) post-treatment

\section{Secondary outcomes}

1. Sore throat

2. Fever

3. Duration of illness

4. Incidence of relapse

5. Incidence of complications (suppurative complications, acute rheumatic fever, post-streptococcal glomerulonephritis)

6. Adverse events

\section{Search methods for identification of studies}

\section{Electronic searches}

For this update we searched the Cochrane Acute Respiratory Infections Group's Specialised Register (25 March 2016); the Cochrane Central Register of Controlled Trials (CENTRAL; 2016, Issue 11), in the Cochrane Library (searched 25 March 2016); MEDLINE Ovid (1966 to March week 3 2016); Embase Elsevier (1974 to 25 March 2016) and Web of Science Thomson Reuters (2010 to 25 March 2016). Search strategies for previous versions of this review are presented in Appendix 1. Details of the current MEDLINE and CENTRAL search strategy are in Appendix 2, Embase is in Appendix 3 , and Web of Science is in Appendix 4.

We did not impose any language or publication restrictions. 


\section{Searching other resources}

We searched the World Health Organization International Clinical Trials Registry Platform (WHO ICTRP), and the US National Institutes of Health Ongoing Trials Register for completed and ongoing trials (www.clinicaltrials.gov). We used the terms streptococcal AND pharyngitis (latest search 25 March 2016). We also searched reference sections of the identified reviews and trials for additional trials; independent sources of drug information (journals of the International Society of Drug Bulletins (electronically and by hand); and proceedings of meetings and conferences for additional references of trials. We contacted pharmaceutical companies producing antibiotics applied in treating pharyngitis for published or unpublished trials on their products, and experts in the field for additional references.

\section{Data collection and analysis}

\section{Selection of studies}

Two review authors (MVD, NK) independently assessed all trials with relevant titles or abstracts, or both, identified by the search to determine which met the inclusion criteria. We excluded all trials that did not meet our inclusion criteria. Trials that were closely assessed for inclusion but subsequently excluded are listed in the Characteristics of excluded studies table. The search results are reported in a PRISMA flow diagram (Figure 1).

Figure 1. Study flow diagram.

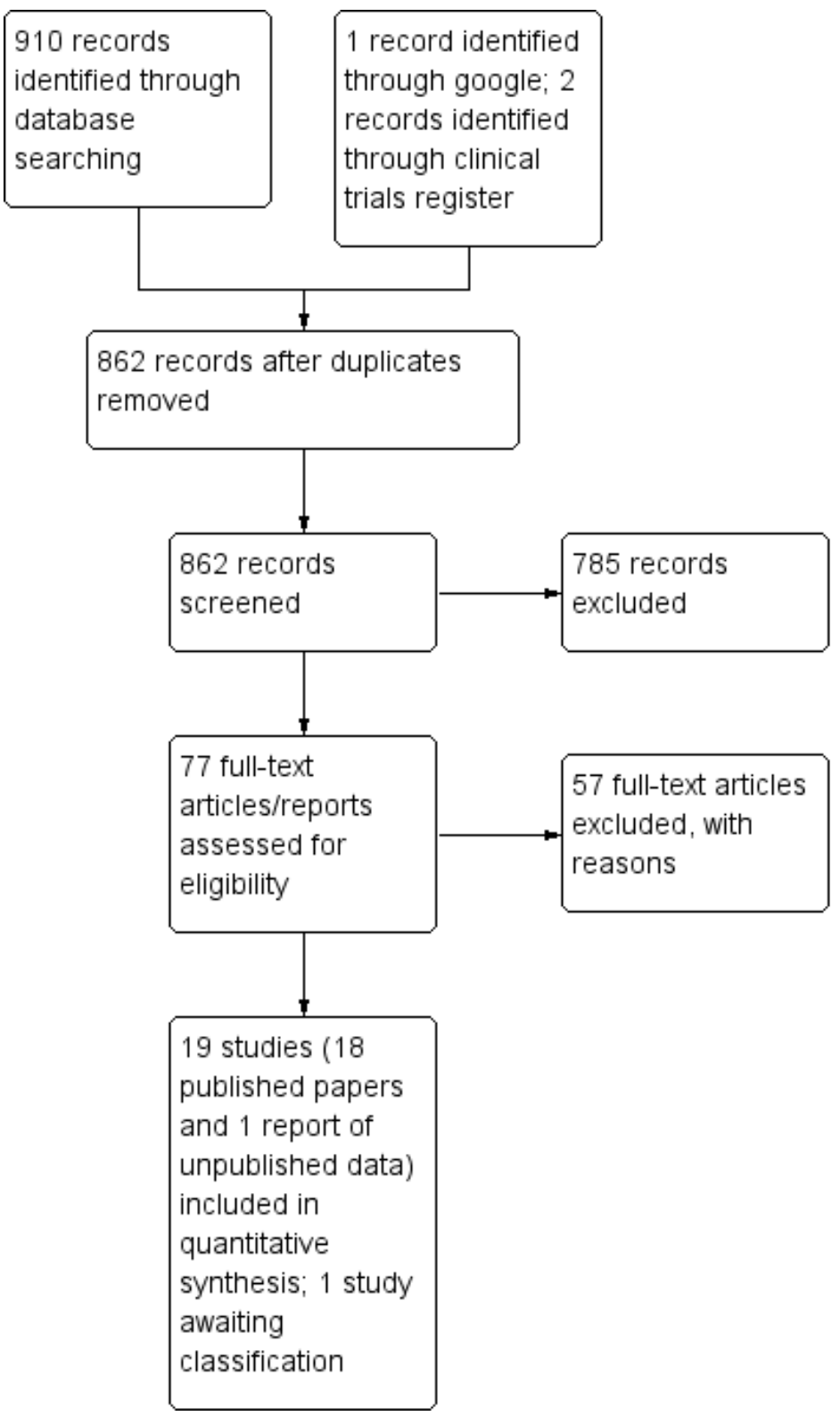




\section{Data extraction and management}

Two review authors (MVD, NK) independently extracted data, using a standard checklist we developed for the review. The standard data extraction form included the following general information: published/unpublished, title, authors, source, contact address, country, language of publication, year of publication, duplicate publications, sponsoring, and setting. It also included data on the following domains:

1. Methods: randomisation procedure, allocation, blinding (participants, people administering treatment, outcome assessors), duration of study, design, analysis (intention-to-treat (ITT)).

2. Participants: number, age, diagnostic criteria, history, baseline characteristics.

3. Interventions: dose, route, timing, duration; comparison group.

4. Outcomes: outcomes specified above, any other outcomes assessed, other events, length of follow-up.

5. Results: for outcomes and times of assessment (including a measure of variation).

\section{Assessment of risk of bias in included studies}

Two review authors (MVD, NK) assessed the methodological quality of the included trials by using Cochrane's risk of bias tool (Higgins 2011). The same review authors independently assessed each trial. We assessed risk of bias for: selection bias (random number generation and allocation concealment), performance and detection bias (blinding), attrition bias (incomplete outcome data), and reporting bias (selective reporting). We assessed studies as low risk of bias (methods clearly described and deemed adequate), high risk of bias (methods described and inadequate or not described and deemed likely to be inadequate), or unclear bias (insufficient information to assess the methods, however no obvious indication for use of inadequate methods).

\section{Measures of treatment effect}

We used Review Manager 5 software for statistical analysis and data pooling (RevMan 2014). If possible, we summarised data in a metaanalysis and performed analyses according to ITT analysis. This means that the number of participants randomised was used as the denominator for each outcome. We considered the participants for whom an outcome was not reported as treatment failures. For dichotomous outcomes, we expressed results as ORs, with $95 \% \mathrm{Cls}$. For statistically significant results we calculated NNTB and NNTH where possible.

\section{Unit of analysis issues}

We did not include any cluster-randomised studies. All included studies reported outcomes at the level of the randomised unit, the individual patient.

\section{Dealing with missing data}

We assessed the impact of missing data on the overall outcome of the meta-analysis by comparing analysis of on-treatment (or evaluable patients) and ITT data.

\section{Assessment of heterogeneity}

We assessed heterogeneity among trial results by calculating a $\mathrm{Chi}^{2}$ test (significance defined as $\mathrm{P}<0.10$ ) and the $\mathrm{I}^{2}$ statistic (Higgins 2003).

\section{Assessment of reporting biases}

We did not identify a sufficient number of studies to assess the presence of publication bias by means of a funnel plot.

\section{Data synthesis}

We pooled dichotomous data using a random-effects model (Higgins 2011). We used a random-effects model for pooling (DerSimonian 1986), but in the absence of statistical heterogeneity (using a cut-off point of $\mathrm{I}^{2}<20 \%$ ), we also pooled data using the fixed-effect model and compared outcomes (Mantel 1959). We used RevMan 2014 software for pooling.

\section{GRADE and 'Summary of findings' table}

For assessment of the overall quality of evidence for the pooled studies, we used the GRADE approach (Atkins 2004), with GRADEpro software (GRADEproGDT 2014). We used the five GRADE considerations (study limitations, consistency of effect, imprecision, indirectness, and publication bias) to assess the quality of evidence as it relates to the studies which contribute data to the meta-analyses for the prespecified outcomes. We created summary of findings tables for the following comparisons: cephalosporin versus penicillin (Summary of findings for the main comparison; Analysis 1.1; Analysis 1.2; Analysis 1.6; Analysis 1.8) and macrolide versus penicillin (Summary of findings 2; Analysis 2.1; Analysis 2.2; Analysis 2.5; Analysis 2.6). We assessed the quality of evidence for the primary outcome (resolution of symptoms, both ITT and evaluable patient analysis), and secondary outcomes (incidence of relapse and incidence of adverse events). We justified all decisions to down- or up-grade the quality of studies using footnotes to aid readers' understanding of the review where necessary.

\section{Subgroup analysis and investigation of heterogeneity}

We stratified the trials into subcategories according to the comparisons between different classes of antibiotics. For each comparison we reported and pooled the predefined outcomes, if possible, in a meta-analysis. We performed subgroup analyses for trials with children versus adults.

We reported ITT data for clinical outcomes and analysis of evaluable participants (i.e. only including in the analysis participants for whom outcome reporting was complete) to illustrate any differences between analysis methods. Analysis of relapse incidence was analysed by including only evaluable participants; an ITT analysis would have seriously overestimated the importance of relapse, and results would not be relevant to clinical practice.

\section{Sensitivity analysis}

We performed a sensitivity analysis of the impact of heterogeneity on the overall effect estimate by first pooling all studies and subsequently removing studies one by one, starting with the studies that appeared (by inspection of the forest plot) to be contributing to the heterogeneity. We also performed sensitivity analysis by applying both random-effects and fixed-effect models 
in the absence of statistical heterogeneity $\left(I^{2}<20 \%\right)$. A meaningful sensitivity analysis was only possible for resolution of symptoms in the comparison of cephalosporin versus penicillin.

\section{RESULTS}

\section{Description of studies}

\section{Results of the search}

We retrieved 385 search results from our electronic searches to October 2012. We retrieved an additional 216 records in the December 2014 search and anther 258 records in the March 2016 search. We identified one additional trial through a Google search (Muller 1992). We identified two references to completed (unpublished) studies on ClinicalTrials.gov in the 2014 search (NCT00643149; NCT00393744). We reviewed a total of 77 trials for this review. Of these, 21 met the predefined inclusion criteria. Two of the 21 papers reported different outcomes of the same study and were considered as one single study (Norrby 2002). The unpublished report of one study registered and marked as completed on ClinicalTrials.gov was made available by Pfizer upon request in 2013 and was included in the 2016 update (NCT00643149). Of the two additional studies that we identified in the March 2016 search, we excluded one (Stillerman 1970), and one was available in abstract form only and is awaiting classification pending information from the authors (Eslami 2014). See PRISMA flow diagram (Moher 2009; Figure 1).

\section{Included studies}

We included 18 trials in the first version of this review (van Driel 2010). Henness 1982 reported two separate trials and we split this into two parts to clarify which trial was assessed (Henness 1982study 1 ; Henness 1982-study 2). We identified one new study in the 2012 update (NCT00643149), and no new studies in the 2014 update. We did not add any new studies in the 2016 update. We included a total of 19 trials in this review. Most included trials were conducted in the 1990s, three in the 1980s (Henness 1982-study 1; Henness 1982-study 2; Randolph 1985), and two in the 1970s (Jackson 1973; Trickett 1973). Only two trials were more recent (Norrby 2002; NCT00643149). All but one trial reported clinical outcomes (Henness 1982-study 2).

Contacting pharmaceutical companies did not result in any additional published or unpublished data (only one company replied); neither did contacting authors or experts in the field. We identified the NCT00643149 study through searching a clinical trials register and we subsequently obtained a report from the manufacturer.

All but two of the included studies compared penicillin with another antibiotic class. Henness 1982 compared penicillin V with cefadroxil in both study 1 and study 2, but added two additional study arms in study 2 (erythromycin, benzathine penicillin G/procaine penicillin). Jackson 1973 compared clindamycin with ampicillin and NCT00643149 compared azithromycin with amoxicillin.

The included trials investigated a total of 5839 randomised participants with acute GABHS tonsillopharyngitis. Participants' ages ranged from one month to 80 years. Nine trials included only, or predominantly, children (Disney 1992a; Disney 1992b; Henness 1982-study 1; Henness 1982-study 2; Jackson 1973; O'Doherty 1996; NCT00643149; Randolph 1985; Reed 1991). Ten trials included participants who were at least 12 years of age or older (Bachand 1991; Carbon 1995; Levenstein 1991; McCarty 1992a; Muller 1992; Nemeth 1999; Norrby 2002; Stein 1991; Trickett 1973; Watkins 1997). In Reed 1991, approximately $80 \%$ of participants were under 15 years of age and therefore included in the subgroup analysis for children. In Muller 1992, 90\% of participants were aged over 12 years; however, because results were not stratified by age group, this study was included in the adult subgroup analysis.

All trials included only participants with confirmed acute GABHS tonsillopharyngitis. Confirmation of the presence of GABHS in participants with clinical signs of tonsillopharyngitis was mostly performed first by a rapid immunoassay test and reconfirmed with a throat culture. In five trials, the confirmation of GABHS tonsillopharyngitis was carried out only by a throat culture (Henness 1982-study 1; Henness 1982-study 2; Jackson 1973; Randolph 1985; Trickett 1973), and in two trials only with a rapid immunoassay test (O'Doherty 1996; Stein 1991). All but one trial reported on clinical outcomes. Trickett 1973 only reported bacteriological outcomes, but was included in the meta-analysis on adverse effects.

Clinical outcomes, in most studies defined as complete resolution of signs and symptoms (Characteristics of included studies), were assessed at various time points, but mostly measured between five to 10 days following the end of antibiotic treatment. Therefore, post-treatment the outcome 'post-treatment clinical efficacy' (i.e. assessment of signs and symptoms after completion of the treatment course) was pooled. Randolph 1985 reported clinical effect within the first 24 hours of treatment. NCT00643149 assessed clinical effects on days 24 to 28 after starting the study drug. Three trials reported on specific symptoms, such as sore throat and fever (Bachand 1991; Levenstein 1991; Randolph 1985). None reported data on the duration of illness. Henness 1982-study 2 did not report any clinical outcomes.

Twelve trials reported the incidence of clinical relapse (Bachand 1991; Carbon 1995; Disney 1992a; Disney 1992b; Levenstein 1991; McCarty 1992a; Muller 1992; Nemeth 1999; Norrby 2002; O'Doherty 1996; Reed 1991; Stein 1991). The definition of clinical relapse varied slightly; from "pretreatment signs and symptoms resolved but reappeared" (Bachand 1991; Carbon 1995; Disney 1992b; Levenstein 1991; McCarty 1992a; Muller 1992; Nemeth 1999; Norrby 2002; Stein 1991) or "initial improvement or alleviation of symptoms, but subsequent worsening or recurrence" (McCarty 1992a; Watkins 1997) to "new infection with different serotype" (Disney 1992a). One study defined clinical cure as "clinical improvement within first 24 hours of therapy and all follow-up cultures no $S$ pyogenes" (Henness 1982-study 1). Two studies used the physician's assessment of symptoms as outcome (Randolph 1985; Reed 1991).

Four trials reported complications occurring during longer followup (Carbon 1995; Jackson 1973; McCarty 1992a; Muller 1992). Fifteen trials mentioned adverse effects reported during treatment. Jackson 1973 only reported bacteriological outcomes and clinical adverse events.

The use of antipyretic analgesics was allowed in four trials (Bachand 1991; Disney 1992b; Muller 1992; Watkins 1997), prohibited in two (Carbon 1995; Randolph 1985), and not stated in the other 13 trials. 
The percentage of patients who dropped out before outcome measurement varied. Some studies did not seem to have any dropouts (Henness 1982-study 1; Henness 1982-study 2; Randolph 1985 ) or lost $20 \%$ or fewer of the randomised participants at the time of outcome evaluation (Carbon 1995; Disney 1992b; Jackson 1973; Levenstein 1991; Norrby 2002; NCT00643149; Reed 1991). Six studies reported drop out rates between 20\% and 30\% (Bachand 1991; McCarty 1992a; Muller 1992; Nemeth 1999; O'Doherty 1996; Stein 1991), and in Watkins 1997, reportedly $38 \%$ of patients dropped out before the end of the study. The most commonly reported reason for dropout was negative culture for GABHS.

\section{Excluded studies}

We excluded 57 studies. The most common reason for exclusion (38 trials) was no or inadequate blinding (Adam 1994; Adam 1995; Adam 1996; Adam 2000a; Adam 2000b; Adam 2001; Aujard 1995; Bottaro 2012; Cohen 2002; Denny 1953; Dykhuizen 1996; Esposito 2002; Feder 1999; Gerber 1986; Gooch 1993; Hamill 1993; Holm 1991; Howe 1997; Kuroki 2013; Lennon 2008; McCarty 1992b; McCarty 1994; Milatovic 1991; Milatovic 1993; Pacifico 1996; Perkins 1969; Pichichero 2000; Pichichero 2008; Portier 1990; Portier
1994; NCT00393744; Sakata 2008; Shapera 1973; Shvartzman 1993; Stillerman 1986; Tack 1997; Tack 1998; Uysal 2000). Seven trials did not compare at least two different classes of antibiotics (Breese 1974; Disney 1979; Matsen 1974; Mclsaac 2004; Rimoin 2011; Siegel 1961; Zwart 2000). In two trials the included participants did not exclusively have acute GABHS tonsillopharyngitis (Davies 1995; Standaert 1997), and one trial included patients with recurrent tonsillitis (Roos 1997). Two trials did not report any clinical outcomes (Gerber 1999a; Stillerman 1970); one was a meta-analysis (Cruz 2011); two were reviews (Stelter 2014; Van Brusselen 2014); and four were not RCTs (Del Mar 2008; De Meyere 1992; Granizio 2008; Haverkorn 1971).

\section{Risk of bias in included studies}

Risk of bias assessment is reported in Characteristics of included studies and illustrated in Figure 2 and Figure 3. Only three trials reported ITT analysis for efficacy outcomes (Disney 1992a; Norrby 2002; Randolph 1985). One trial reported carrying out an ITT analysis, but post-randomisation exclusions were not included in the efficacy analysis (Carbon 1995). All trial authors used an ITT analysis for adverse effects. 
Figure 2. 'Risk of bias' summary: review authors' judgements about each risk of bias item for each included study.

\begin{tabular}{|c|c|c|c|c|c|c|}
\hline & 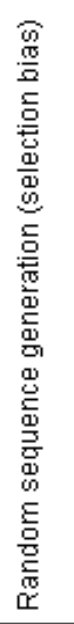 & 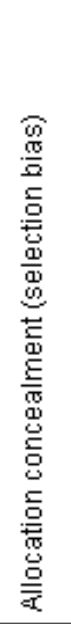 & 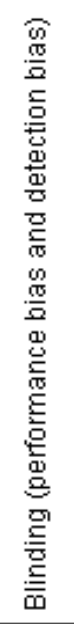 & 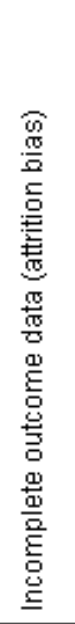 & 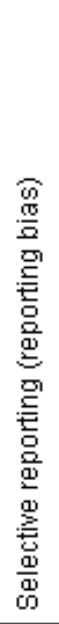 & 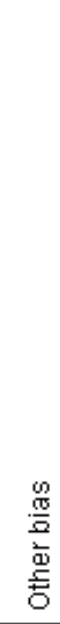 \\
\hline Bachand 1991 & $?$ & $?$ & + & $\Theta$ & $?$ & $\odot$ \\
\hline Carbon 1995 & $?$ & $?$ & $?$ & $\odot$ & $?$ & $?$ \\
\hline Disney 1992a & $?$ & $?$ & $\odot$ & $\odot$ & $?$ & 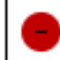 \\
\hline Disney $1992 b$ & $?$ & $?$ & + & + & $?$ & - \\
\hline Henness 1982 & $?$ & $?$ & $?$ & $\Theta$ & $?$ & 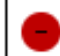 \\
\hline Jackson 1973 & $?$ & $\odot$ & $\odot$ & $\odot$ & $?$ & 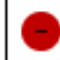 \\
\hline Levenstein 1991 & $?$ & $?$ & $\odot$ & $\odot$ & $?$ & $?$ \\
\hline McCarty 1992a & $?$ & $?$ & $\odot$ & $\Theta$ & $?$ & - \\
\hline Muller 1992 & $?$ & $?$ & $\odot$ & 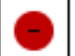 & $?$ & - \\
\hline NCT00643149 & $?$ & $?$ & 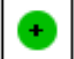 & $\odot$ & $?$ & - \\
\hline Nemeth 1999 & $?$ & $?$ & $?$ & 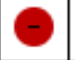 & $?$ & 0 \\
\hline Norrby 2002 & $?$ & $?$ & 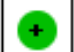 & + & $?$ & - \\
\hline O'Doherty 1996 & $?$ & $?$ & $\odot$ & 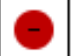 & $?$ & $?$ \\
\hline Randolph 1985 & 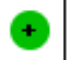 & + & + & + & $?$ & - \\
\hline Reed 1991 & $?$ & + & + & $\Theta$ & $?$ & - \\
\hline Stein 1991 & $?$ & $?$ & $\odot$ & $\odot$ & $?$ & $?$ \\
\hline Trickett 1973 & $?$ & $?$ & $\odot$ & + & $?$ & ? \\
\hline Watkins 1997 & $\oplus$ & 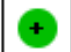 & 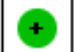 & 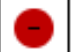 & $?$ & - \\
\hline
\end{tabular}


Figure 3. 'Risk of bias' graph: review authors' judgements about each risk of bias item presented as percentages across all included studies.

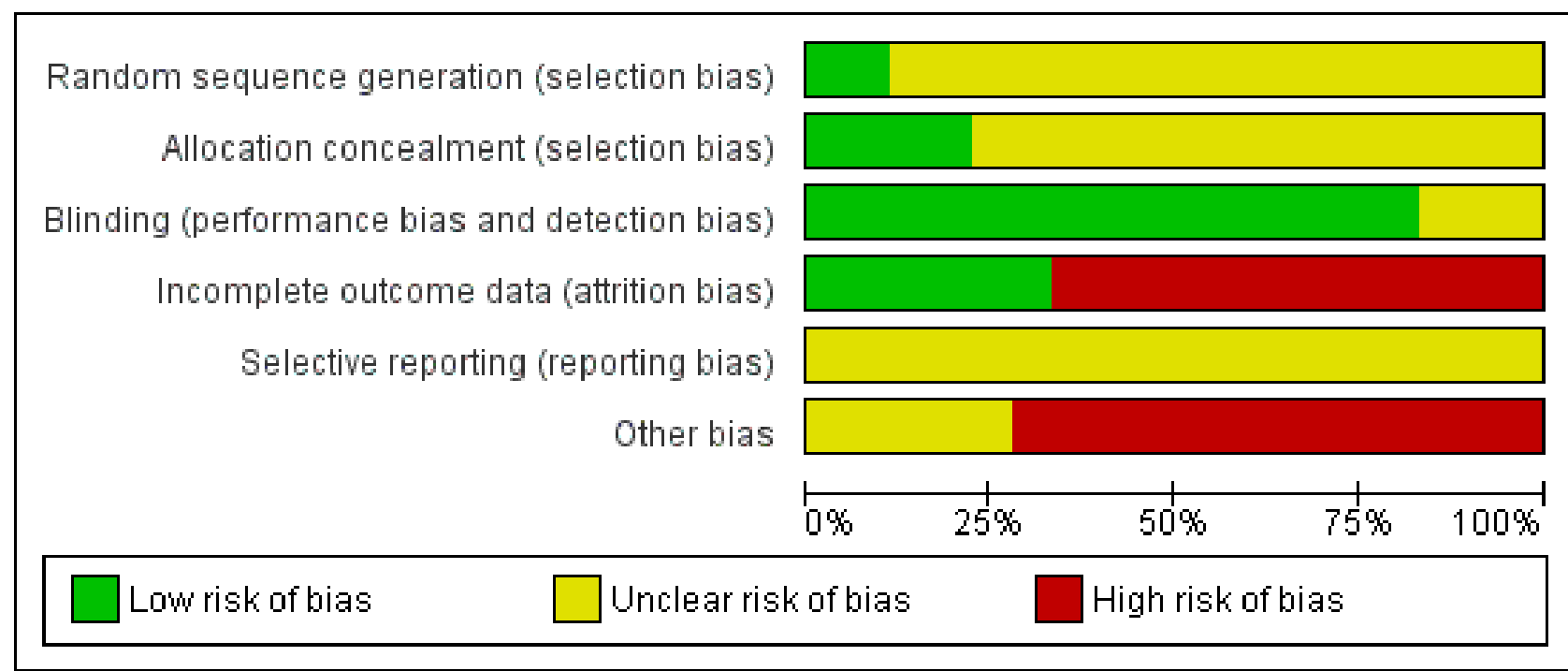

\section{Allocation}

All trials were randomised, but only four described methods of randomisation or allocation concealment, or both (Jackson 1973; Randolph 1985; Reed 1991; Watkins 1997).

Random sequence generation was described and deemed adequate in two studies (Randolph 1985; Watkins 1997) and not described (assessed as unclear risk) in the remaining studies.

Allocation concealment was described and assessed as adequate in four studies (Jackson 1973; Randolph 1985; Reed 1991; Watkins 1997) and not described (assessed as unclear risk) in the other studies.

\section{Blinding}

All trials were double-blinded and methods of blinding were described in 14 trials (Disney 1992a; Disney 1992b; Jackson 1973; Levenstein 1991; McCarty 1992a; Muller 1992; Norrby 2002; O'Doherty 1996; NCT00643149; Randolph 1985; Reed 1991; Stein 1991; Trickett 1973; Watkins 1997).

Blinding of participants and personnel was reported and assessed as low risk of bias in 15 trials (Bachand 1991; Disney 1992a; Disney 1992b; Jackson 1973; Levenstein 1991; McCarty 1992a; Muller 1992; NCT00643149; Norrby 2002; O'Doherty 1996; Randolph 1985; Reed 1991; Stein 1991; Trickett 1973; Watkins 1997). In four studies (Carbon 1995; Henness 1982-study 1; Henness 1982-study 2 ; Nemeth 1999) this was not reported and assessed as unclear risk of bias.

Blinding of outcome assessors was reported and assessed as low risk of bias in only one trial (Randolph 1985). This was not reported and hence assessed as unclear risk of bias in all other included studies.

\section{Incomplete outcome data}

The post-randomisation dropout rate was high in most trials. In 12 trials the proportion of dropouts was more than $20 \%$ (Bachand 1991; Henness 1982-study 1; Jackson 1973; Levenstein
1991; McCarty 1992a; Muller 1992; NCT00643149; Nemeth 1999; O'Doherty 1996; Reed 1991; Stein 1991; Watkins 1997), ranging from $21.5 \%$ in McCarty 1992 a to $48.5 \%$ in Levenstein 1991 . In the outcome analysis most trials included only participants with complete outcome data. This may have had an important impact on the effect measured, and therefore, these studies were assessed as high risk of attrition bias.

Only four trials reported an ITT analysis with all randomised participants included in the analysis of the clinical outcome (Disney 1992a; Disney 1992b; Norrby 2002; Randolph 1985). These trials had minimal to no dropouts ( 0 or 1 participant) and were assessed as low risk of attrition bias. Carbon 1995, Henness 1982-study 2 and Trickett 1973 were also assessed as low risk of attrition bias because of a low post-randomisation dropout rate.

None of the studies were assessed as unclear risk of attrition bias.

\section{Selective reporting}

All included studies were assessed as unclear risk for selective reporting; pre-publication protocols were not available.

\section{Other potential sources of bias}

Eleven trials reported sponsorship by a pharmaceutical company (Disney 1992a; Disney 1992b; Jackson 1973; McCarty 1992a; Muller 1992; Nemeth 1999; Norrby 2002; Randolph 1985; Reed 1991; Trickett 1973; Watkins 1997). NCT00643149 was unpublished and obtained from the company that conducted the trial (Pfizer). Authors of six trials were reported to be employees of a pharmaceutical company (Bachand 1991; Disney 1992b; Henness 1982-study 1; Henness 1982-study 2; Nemeth 1999; Watkins 1997), and in three of those, the employing pharmaceutical company was not reported as a funding source (Bachand 1991; Henness 1982study 1; Henness 1982-study 2). These fourteen trials were assessed as high risk of bias in this domain. The remaining five trials did not mention funding sources and were assessed as 'unclear risk of bias' in this domain. 
Six trials mentioned that ethics approval was obtained for the study (Bachand 1991; Levenstein 1991; Muller 1992; Nemeth 1999; Norrby 2002; O'Doherty 1996), and seven trials reported that informed consent was obtained from participants or guardians (Levenstein 1991; McCarty 1992a; Muller 1992; Nemeth 1999; Norrby 2002; O'Doherty 1996; Reed 1991).

\section{Effects of interventions}

See: Summary of findings for the main comparison Cephalosporins compared to penicillin for group A streptococcal pharyngitis; Summary of findings 2 Macrolides compared to penicillin for group A streptococcal pharyngitis

\section{Cephalosporin versus penicillin}

Six trials contributed to the pooled analysis within this comparison (Carbon 1995; Disney 1992a; Henness 1982-study 1; Nemeth 1999; Randolph 1985; Reed 1991). We assessed the overall quality of evidence for the primary outcome, resolution of symptoms posttreatment as low for the ITT analysis in the total study population and in the subgroup analysis for adults, but very low for the analysis of evaluable patients and ITT analysis in children. The quality of the pooled effect estimate was assessed as low for the outcome incidence of relapse (evaluable patients) and very low for the outcome adverse events (ITT analysis). We downgraded the quality due to unclear randomisation and blinding, wide confidence intervals, and heterogeneity when pooling the studies (see Summary of findings for the main comparison).

\subsection{Primary outcome: Resolution of symptoms post-treatment}

Six trials reported on the resolution of symptoms at various points in time (Carbon 1995; Disney 1992a; Henness 1982-study 1; Nemeth 1999; Randolph 1985; Reed 1991). See also Summary of findings for the main comparison.

Five trials measured resolution of symptoms at the end of treatment ( 2 to 15 days or more post-treatment); two trials in adults (Carbon 1995; Nemeth 1999), and three in children (Disney 1992b; Henness 1982-study 1; Reed 1991). The ITT analysis included 2018 participants and showed no difference between treatments (OR $0.79,95 \% \mathrm{Cl} 0.55$ to 1.12; low quality evidence; Analysis 1.1; Summary of findings for the main comparison). The effect in adults (OR $0.78,95 \% \mathrm{Cl} 0.60$ to $1.01 ; \mathrm{N}=2, \mathrm{n}=1163$; low quality evidence) was similar to that in children (OR $0.83,95 \% \mathrm{Cl} 0.40$ to $1.73 ; \mathrm{N}=3$, $\mathrm{n}=855$; low quality evidence).

The result of the analysis of evaluable participants only showed an effect in favour of treatment with cephalosporins (OR 0.51, $95 \% \mathrm{Cl} 0.27$ to 0.97 ; ARD 0.05 , NNTB $20, \mathrm{n}=1660$; very low quality evidence; Analysis 1.2; Summary of findings for the main comparison). However, the estimates of effect in adults (OR 0.56 $95 \% \mathrm{Cl} 0.24$ to $1.32 ; \mathrm{N}=2, \mathrm{n}=880$ ) and in children (OR $0.46,95 \%$ $\mathrm{Cl} 0.14$ to $1.52 ; \mathrm{N}=3, \mathrm{n}=780$ ) analysed separately revealed no statistically significant differences between treatment groups.

We analysed the studies with reported pharmaceutical company sponsorship separately for the outcome resolution of symptoms post-treatment. Two studies that did not report funding sources showed a statistically significant effect in favour of cephalosporins (OR 0.47, 95\% Cl 0.27 to 0.81; ARD 0.02, NNTB 50; Carbon 1995; Disney 1992a). Pooling sponsored studies did not result in a significant difference between antibiotic groups (Henness 1982study 1; Nemeth 1999; Reed 1991). See Analysis 1.9.

One trial in children $(n=138)$ also reported resolution of symptoms within 24 hours of treatment (Randolph 1985), and found no difference between treatment groups (OR $0.97,95 \% \mathrm{Cl} 0.34$ to 2.74 ). See Analysis 1.3.

A sensitivity analysis revealed that in the ITT analysis, the trial by Disney 1992a contributed to the heterogeneity of the analysis in children. However, removing this trial from the analysis did not result in a significant change in the overall outcome. In a similar analysis for the evaluable patients only, the trial by Reed 1991 appeared to contribute most to the heterogeneity. After removing this trial, the $I^{2}$ statistic was no longer important. Pooling the two remaining trials in children showed a statistically significant benefit in favour of cephalosporins in children. However, the overall effect in all participants remained non-significant.

\subsection{Secondary outcomes}

\subsubsection{Sore throat}

One trial in children found no difference between treatment groups for resolution of sore throat (OR $0.97,95 \% \mathrm{Cl} 0.23$ to $4.04 ; n=138$; Analysis 1.4; Randolph 1985).

\subsubsection{Fever}

One trial in children found no difference between treatment groups for resolution of fever (OR $0.97,95 \% \mathrm{Cl} 0.19$ to $4.98 ; \mathrm{n}=138$; Analysis 1.5; Randolph 1985).

\subsubsection{Duration of illness}

Not reported.

\subsubsection{Incidence of relapse}

In four trials $(n=1386)$ that reported the incidence of clinical relapse in evaluated participants there was a benefit of treatment with cephalosporins over penicillin in the total population (OR 0.55, 95\% Cl 0.30 to 0.99; ARD 0.02, NNTB 50; Carbon 1995; Disney 1992a; Nemeth 1999; Reed 1991). This was due to a difference in two trials in adults (OR 0.42, 95\% Cl 0.20 to 0.88; ARD 0.03, NNTB 33.3, $\mathrm{n}=770$; Carbon 1995; Nemeth 1999). There was no difference between trials in children (OR 0.89, $95 \% \mathrm{Cl} 0.33$ to $2.45 ; \mathrm{n}=616$; Analysis 1.6; Disney 1992a; Reed 1991).

\subsubsection{Incidence of complications}

In one trial in adults no complications were reported in the cephalosporin group (119 participants) or the penicillin group (125 participants) (Carbon 1995)

\subsubsection{Adverse events}

Three trials in adults reported the incidence of adverse effects (Carbon 1995; Nemeth 1999; Reed 1991). There was significant heterogeneity among the trials. In the cephalosporin group, 212 of 788 participants reported adverse events, compared with 87 of 491 in the penicillin group. There was no difference between treatments (OR 0.94, 95\% Cl 0.27 to 3.25; Analysis 1.8).

The reported adverse events were predominantly gastrointestinal (diarrhoea, nausea and vomiting, constipation), but also vaginal moniliasis and headaches have been reported with both antibiotic classes (Carbon 1995; Nemeth 1999). Reed 1991 did not report the 
nature of the adverse events. None of the adverse events were serious. Carbon 1995 reported one patient with penicillin allergy.

\section{Macrolide versus penicillin}

Six trials contributed to the pooled analysis within this comparison (Bachand 1991; Levenstein 1991; Norrby 2002; O'Doherty 1996; Stein 1991; Watkins 1997). We assessed the overall quality of the evidence for the primary outcome, resolution of symptoms, and for incidence of relapse and for adverse events as low. We downgraded the quality due to unclear randomisation and blinding, and wide confidence intervals (see Summary of findings 2).

\subsection{Primary outcome: Resolution of symptoms post-treatment}

Five trials in adults (Bachand 1991; Levenstein 1991; Norrby 2002; Stein 1991; Watkins 1997), and one in children (O'Doherty 1996), investigated the resolution of symptoms at various points in time post-treatment. In the ITT analysis of 1728 participants there were no differences between the treatment groups (OR 1.11, 95\% Cl 0.92 to 1.35 ; low quality evidence; Analysis 2.1; Summary of findings 2). The estimate of effect in adults (OR $1.07,95 \% \mathrm{Cl} 0.86$ to $1.34 ; \mathrm{N}=$ $5, \mathrm{n}=1239$ ) was similar to children (OR $1.25,95 \% \mathrm{Cl} 0.85$ to 1.84 ; $n=489$ ). The analysis of evaluable participants only did not result in any significant differences between treatment groups (OR 0.79, $95 \% \mathrm{Cl} 0.57$ to $1.09 ; \mathrm{n}=1159$; low quality evidence; Analysis 2.2; Summary of findings 2). The estimate for the five trials in adults ( $\mathrm{n}$ $=801$ ) was OR $0.88,95 \% \mathrm{Cl} 0.59$ to 1.31 , and one trial in children ( $\mathrm{n}$ $=358)$ was OR $0.64,95 \% \mathrm{Cl} 0.36$ to 1.11 .

ITT analysis of pharmaceutical industry sponsored trials versus trials that did not report funding sources did not show significant differences in results (Analysis 2.7).

\subsection{Secondary outcomes}

\subsubsection{Sore throat}

Two trials reported resolution of sore throat in adults, and found no difference between the treatments $(\mathrm{OR} 0.97,95 \% \mathrm{Cl} 0.64$ to 1.46 ; $\mathrm{n}$ = 371; Analysis 2.3; Bachand 1991; Levenstein 1991).

\subsubsection{Fever}

Resolution of fever at two to 10 days post-treatment was reported in two trials with 371 adult participants (Bachand 1991; Levenstein 1991). All participants in both groups were free of fever at the time they were evaluated (45 participants in the macrolide group and 39 in the penicillin group; OR 1.05, 95\% $\mathrm{Cl} 0.69$ to 1.59; Analysis 2.4).

\subsubsection{Duration of illness}

Not reported.

\subsubsection{Incidence of relapse}

Incidence of clinical relapse was evaluated in six trials; five trials in adults (Bachand 1991; Levenstein 1991; Norrby 2002; Stein 1991; Watkins 1997), and one in children (O'Doherty 1996). Twenty-two of 441 participants in the macrolide group and 16 of 361 in the penicillin group reported relapse at day 15 to 56 post-treatment. The difference was not statistically significant (OR 1.21, 95\% Cl 0.48 to 3.03; Analysis 2.5; Summary of findings 2).

\subsubsection{Incidence of complications}

Not reported.

\subsubsection{Adverse events}

In the six trials ( $\mathrm{n}=1727)$, five in adults and one in children (O'Doherty 1996), that reported on the incidence of adverse events, there were no statistically significant differences between treatment groups: 282 events were reported in the macrolide group and 251 in the penicillin group (OR $1.19,95 \% \mathrm{Cl} 0.82$ to 1.73 ; Summary of findings 2). In the trial in children, macrolides seemed to cause more adverse events than penicillin (OR 2.33, 95\% Cl 1.06 to $5.15 ; n=489$, NNTH 17.2; Analysis 2.6).

The reported adverse events were predominantly gastrointestinal (diarrhoea, nausea and vomiting, constipation, abdominal pain), but vaginal moniliasis and headaches and dizziness were also reported with both antibiotic classes. Rash was reported in patients taking penicillin (O'Doherty 1996). Most studies did not report any serious adverse events, but Levenstein 1991 reported two serious events - depression and balanitis.

\section{Azithromycin versus amoxicillin}

\subsection{Primary outcome: Resolution of symptoms post-treatment}

One trial (unpublished data provided by Pfizer) studied the effect of a single dose of azithromycin versus 10 days of amoxicillin in 673 children (NCT00643149). The clinical cure rate was reported for the 'bacteriological per protocol population' only, which was defined as those with GABHS-positive culture within 48 hours of treatment start, at least eight days of treatment (compliance) and available data at baseline. Effects were measured at 24 to 28 days after commencing treatment and on days 38 to 42 . In the azithromycin group 239/245 participants achieved clinical cure at the first evaluation point versus $218 / 237$ in the amoxicillin group (OR fixed-effect $0.29,95 \% \mathrm{Cl} 0.11$ to 0.73 ; NNTB 18; Analysis 3.2). The difference was not statistically significant in the ITT analysis (OR 0.76, $95 \% \mathrm{Cl} 0.55$ to 1.05 ; Analysis 3.1).

\subsection{Secondary outcomes}

\subsubsection{Sore throat}

Not reported.

\subsubsection{Fever}

Not reported.

\subsubsection{Duration of illness}

Not reported.

\subsubsection{Incidence of relapse}

On days 38 to 45 after treatment commencement, the per protocol population was reduced to 223 in the azithromycin group and 199 in the amoxicillin group. The incidence of relapse did not differ between groups in the ITT analysis (OR $0.75,95 \% \mathrm{Cl} 0.55$ to 1.02 ; Analysis 3.3) or the bacteriological per protocol population (16/223 in the azithromycin group versus 16/199 in the amoxicillin group; OR $0.88,95 \% \mathrm{Cl} 0.43$ to 1.82 ; Analysis 3.4 ).

\subsubsection{Incidence of complications}

Not reported.

\subsubsection{Adverse events}

In total, $57.5 \%$ of participants in the azithromycin group and $56.3 \%$ in the amoxicillin group reported experiencing an adverse 
event. However, reported treatment-related adverse events were more prevalent in the azithromycin group (27.6\%) than in the amoxicillin group (12.5\%); (OR $2.67,95 \% \mathrm{Cl} 1.78$ to 3.99$)$. The most commonly reported adverse events were related to the digestive system (diarrhoea, nausea, vomiting, abdominal pain) and were more common in patients treated with azithromycin (34.1\%) than those treated with amoxicillin (16.1\%). Rash was more common in the amoxicillin group ( $3.0 \%$ versus $0.6 \%$ in the azithromycin group). No deaths or serious adverse events were reported (Analysis 3.5).

\section{Carbacephem versus penicillin}

Three trials were included in this comparison $(n=795)$ : one in children (Disney 1992b), one in adults (McCarty 1992a), and one in a mixed population of adults and children (but predominantly adults; 90\% were aged over 12 years) (Muller 1992).

\subsection{Primary outcome: Resolution of symptoms post-treatment}

In the ITT analysis, more participants reported resolution of symptoms in the carbacephem group than in the penicillin group (OR for absence of symptom resolution post-treatment $0.70,95 \%$ $\mathrm{Cl} 0.49$ to $0.99 ; \mathrm{n}=795$, ARD 0.07, NNTB 14.3; Analysis 4.1). There was no difference in adults (OR $0.75,95 \% \mathrm{Cl} 0.46$ to $1.22 ; \mathrm{n}=562$ ); in children there was a beneficial effect from carbacephem (OR 0.57 , $95 \% \mathrm{Cl} 0.33$ to $0.99 ; \mathrm{n}=233$, ARD 0.12 , NNTB 8.3). The analysis of evaluable participants showed no differences between treatment groups (OR 0.62, 95\% $\mathrm{Cl} 0.38$ to 1.01; $\mathrm{n}=602$; Analysis 4.2).

\subsection{Secondary outcomes}

\subsubsection{Sore throat}

Not reported.

\subsubsection{Fever}

Not reported.

\subsubsection{Duration of illness}

Not reported.

\subsubsection{Incidence of relapse}

There were no differences in the incidence of clinical relapse between groups treated with carbacephem or penicillin (21 events in 267 participants treated with carbacephem and 16 in 256 participants treated with penicillin; OR $1.27,95 \% \mathrm{Cl} 0.64$ to 2.50 ; Analysis 4.3).

\subsubsection{Incidence of complications}

Not reported.

\subsubsection{Adverse events}

There were no differences in reported adverse events between treatments (75 events reported in 396 participants treated with carbacephem and 71 in 399 participants treated with penicillin; OR $1.08,95 \% \mathrm{Cl} 0.75$ to 1.55$)$. Muller 1992 reported that one participant was hospitalised for surgical drainage of a tonsillar abscess in the group treated with loracarbef one day after initiating therapy. See Analysis 4.4.

Reported adverse events were predominantly gastrointestinal (diarrhoea, nausea, vomiting) in all treatment groups. Headaches were reported in McCarty 1992a and Muller 1992, and vaginal moniliasis in McCarty 1992a. Rashes were reported in both treatment groups (Disney 1992b; Muller 1992).

\section{Clindamycin versus ampicillin}

Jackson 1973 compared treatment with clindamycin to ampicillin $(n=314)$. The only clinical outcome reported was adverse events.

\subsection{Primary outcome: Resolution of symptoms post-treatment}

Not reported.

\subsection{Secondary outcomes}

\subsubsection{Sore throat}

Not reported.

\subsubsection{Fever}

Not reported.

\subsubsection{Duration of illness}

Not reported.

\subsubsection{Incidence of relapse}

Not reported.

\subsubsection{Incidence of complications}

Not reported.

\subsubsection{Adverse events}

Six participants reported adverse events in the group treated with clindamycin (156 participants) and 14 participants experienced adverse events in the ampicillin group (158 participants). The difference was not statistically significant (OR $0.41,95 \% \mathrm{Cl} 0.15$ to 1.10; Analysis 5.1). Gastrointestinal adverse events (nausea or vomiting and loose stools) and rash or urticaria occurred in both treatment groups. No other events were reported.

\section{Sulphonamide versus penicillin}

One trial in adults was included in this comparison (Trickett 1973). It reported only on adverse events.

\subsection{Primary outcome: Resolution of symptoms post-treatment}

Not reported.

\subsection{Secondary outcomes}

\subsubsection{Sore throat}

Not reported.

\subsubsection{Fever}

Not reported.

\subsubsection{Duration of illness}

Not reported.

\subsubsection{Incidence of relapse}

Not reported.

\subsubsection{Incidence of complications}

Not reported. 


\subsubsection{Adverse events}

Trickett 1973 reported eight events in participants treated with sulphonamides and six events in the penicillin group; Analysis 6.1. They found no difference between sulphonamide and penicillin (OR 1.37, $95 \% \mathrm{Cl} 0.43$ to 4.34). Gastrointestinal disturbances, rash, (reversible) leukopenia and (reversible) liver and kidney function disturbances were reported in both treatment groups.

\section{Penicillin allergy}

We assessed the reporting of penicillin allergy in all included studies. Carbon 1995 reports one patient with a 'severe allergic reaction' in the penicillin group, but no further details are provided. Muller 1992 reported that one patient developed a rash and another experienced vomiting, both attributed to use of penicillin (although patients were then successfully switched to amoxicillin/ clavulanate). However, in the loracarbef group, also one participant discontinued treatment because of a rash. Trickett 1973 reports one patient with a rash in the penicillin group, but two patients reported a rash in the trimethoprim/sulfamethoxazole group. None of the other studies included in this review specifically report penicillin allergy.

\section{DISCUSSION}

\section{Summary of main results}

Our meta-analysis found generally low quality evidence (as per the GRADE assessment) that did not show clinically important differences in clinical outcomes when different classes of antibiotics were compared with penicillin in adults and children with pharyngitis caused by GABHS.

\section{Resolution of symptoms}

ITT analysis did not show any difference in resolution of symptoms between cephalosporins and penicillin. When only evaluable participants were included in the analysis (i.e. participants for whom an outcome was known) there seemed to be a benefit of cephalosporins over penicillin with regard to resolution of symptoms after treatment (number needed to treat to benefit (NNTB) 20). Subgroup analysis of adults and children (aged between one month and 17 years) did not reveal any significant differences, but this could be attributed to lack of sufficient power.

ITT analysis of carbacephem versus penicillin showed a benefit of carbacephem with regard to resolution of symptoms after treatment (NNTB 14.3). There was no significant benefit in the (large) adult subgroup, and the effect may be largely based on an observed effect in children (aged between six months and 12 years) (NNTB 8.3). The analysis of evaluable participants only did not reach statistical significance (but the estimated NNTB was likely to be high).

Pooling of trials comparing macrolides with penicillin did not result in any differences between groups in terms of resolution of symptoms. Only one unpublished trial in children aged between two and 12 years that compared a single dose of azithromycin with 10 days of amoxicillin found that more children on azithromycin were cured after 24 to 28 days than with amoxicillin. However, this effect was no longer significant in the ITT analysis.

Other comparisons with penicillin (clindamycin or sulphonamides) did not report clinical outcomes for this meta-analysis.

\section{Relapse}

The incidence of relapse in evaluable participants seemed to be lower in participants treated with cephalosporins compared with penicillin, but the event rate was low (approximately 3.5\%) and the NNTB quite high (NNTB 50). There were no differences in relapse rate between other antibiotics and penicillin.

\section{Adverse events}

Adverse events occurred at a similar rate in all treatment groups, except children treated with macrolides, who seemed to experience more adverse events than children treated with penicillin (although this difference was not statistically significant, most likely due to insufficient power) or amoxicillin or ampicillin.

The results of our meta-analysis need to be considered in the context of morbidity (including serious complications) prevalence, concerns about rising antibiotic resistance, and economic constraints in all healthcare systems.

\section{Penicillin allergy}

Incidence of penicillin allergy was poorly if at all reported in the included trials. When a rash is reported in the penicillin group this is often also reported in the comparator group. The limited information about penicillin allergy may reflect the low incidence in the general population. Albin 2014 found that penicillin allergy was reported in $11.5 \%$ of patients in a retrospective chart review, but only $11.8 \%$ of those with a documented allergy had experienced an anaphylactic reaction. The incidence of true anaphylaxis has been reported as less than $0.01 \%$ (Battacharya 2010). It is also possible that patients with known penicillin allergies were excluded from the trials resulting in a low incidence of allergies during the trial. This exclusion was only explicitly mentioned in a few of the included studies.

\section{Overall completeness and applicability of evidence}

Although we searched several databases and scrutinised all references listed in identified reviews and publications of trials, we may have missed some trials. We contacted experts and pharmaceutical companies. One pharmaceutical company responded, but this did not result in additional data. An updated search in 2012 identified an unpublished study, and a report was provided by the manufacturer in 2013 (NCT00643149). This study was included in the 2014 update but we did not identify any new published or unpublished trials in a new search. As an analysis of unpublished data used in Cochrane Reviews suggested that searching for unpublished data generally does not uncover new data that are important to the conclusion of the review (van Driel 2009), the lack of further unpublished data may not have had an important impact on the results of our review.

Our meta-analysis focused on clinical outcomes. Reviews that report bacteriological outcomes point to the superiority of cephalosporins over penicillin with regard to eradication of GABHS (Brunton 2006; Casey 2004). However, this does not take clinical presentation into account. Gerber 1999a found no difference in bacteriologic treatment success rates between cefadroxil and penicillin groups among participants classified clinically as likely to have true GABHS pharyngitis, but cephalosporins seemed to be more successful in eradicating GABHS in patients classified as clinically likely to be streptococcal carriers. Contamination of treatment groups by such chronic GABHS carriers contributes to 
the apparent superiority of cephalosporins in studies focusing on bacteriological outcomes (Shulman 2004); this is of very limited clinical relevance. To our knowledge, chronic streptococcal carriage is not linked to higher risk of developing GABHS pharyngitis, and hence eradication of streptococci in carriers is not a treatment goal. Information on complications is scarcely reported and therefore we could not draw any conclusions concerning this outcome.

Our review included studies involving children and adults, but age ranges of participants in each study varied widely, and there was significant overlap. Therefore, it was not always possible to perform subgroup analyses based on age groups. It was not possible to draw conclusions about specific age groups. This would have been clinically relevant because GABHS is more common in children aged between five and 15 years (Worrall 2007).

\section{Quality of the evidence}

A strength of our review is that we included only randomised and double-blinded trials. This was intended to minimise risk of bias related to participant selection and reporting of outcomes. However, in spite of the lower risk of bias due to methodology, reporting of findings and transparency of analyses in the trials were often unsatisfactory. Patient characteristics were poorly reported and outcomes, poorly, or not at all defined. Dropout rates in some studies were very high (> 20\%).

The overall risk of bias in included studies was difficult to assess because the process of randomisation and blinding was not described in most studies. For instance, only four studies described the method used to conceal allocation (Jackson 1973; Randolph 1985; Reed 1991; Watkins 1997).

It is surprising that resolution of sore throat, a key symptom in GABHS pharyngitis and important reason for patients to consult their doctor (van Driel 2006), was only reported as a separate outcome in one study (McCarty 1992a). Most studies however, assessed our primary outcome which is a composite endpoint consisting of a combination of symptoms including sore throat, fever, and feeling unwell. This is of course also of clinical relevance to patients.

The overall quality of the pooled evidence assessed with the GRADE tool was low for all outcomes in the comparison of macrolides versus penicillin and low or very low for the comparison cephalosporins versus penicillin. We downgraded the quality of evidence mainly because of lack of, or poor reporting of randomisation, or blinding, or both, heterogeneity and wide confidence intervals.

\section{Potential biases in the review process}

Pooling of outcomes was hampered by differences in outcome definitions among studies. Because most trials measured clinical outcomes within two weeks of the end of antibiotic treatment they were pooled for the outcome resolution of symptoms posttreatment. The trial that reported symptom resolution within the first 24 hours of treatment was considered separately. Very few trials reported on specific symptoms related to acute GABHS tonsillopharyngitis. Because symptom resolution is a subjective outcome, the interpretation may differ among trials, and pooling may therefore be inappropriate. However, differences between comparison groups in the same trial were not affected because they were measured in the same population.
We used ITT analysis of the selected outcomes for our metaanalyses. However, this may have underestimated the efficacy of treatment. Most trials reported numbers of participants randomised, but included only the evaluated participants in the outcome analysis. When reported, a common reason for postrandomisation exclusion was negative throat culture, suggesting that another pathogen caused the signs and symptoms of acute tonsillopharyngitis. Including these GABHS-negative participants in the analysis could bias the results if exclusion was not similar in both treatment groups. Some trials reported exclusions per group and show that this is not the case. When comparing two efficacious treatments this potential underestimation did not seem relevant because it did not influence conclusions. However, for trials that did not report this, it was not possible to know if selective exclusions occurred. We checked if the analysis method influenced outcomes by performing both ITT and analysis of evaluable participants for the outcome resolution of symptoms post-treatment. This showed different results in two comparisons. When cephalosporins and penicillin were compared, ITT analysis yielded a non-significant result, whereas analysis of evaluable participants showed a benefit of cephalosporins over penicillin. The opposite occurred in the analysis of effect on the same outcome in participants treated with carbacephem versus penicillin; where ITT analysis showed a statistically significant difference and the evaluable participants analysis did not, most likely due to a reduction in the number of participants included in the analysis (resulting in reduced statistical power). Analysing only evaluable participants implies a high risk of bias as there may have been a selective dropout. On the other hand, the ITT analysis can be considered as a conservative estimate of the true effect.

The estimated odds ratios (ORs) suggested that large benefits could be expected when treating patients with cephalosporins or carbacephems. However, these supposedly impressive effects expressed as a relative measure of risk (ORs) do not always translate into a clinically meaningful difference. For example, the estimated OR of 0.55 for the incidence of relapse in cephalosporins compared with penicillin, suggests that the risk of relapse could be halved by treating patients with cephalosporins. However, the associated absolute risk difference is 0.02 , resulting in a NNTB of 50 , which means that 50 patients need to be treated with broad-spectrum, more expensive antibiotics to prevent one additional relapse.

Calculating the absolute risk difference and the NNTB is therefore a useful method to assess the clinical importance of a relative risk. The interpretation of the NNTBs (how many patients needed to treat is acceptable) is, however, not clear-cut and depends on assessment of benefit and harm and also cost-effectiveness.

All trials in our review were performed in high-income countries. The incidence of suppurative and other complications (which are rare in high-income countries), as well as antimicrobial resistance rates, may be different in low-income countries or specific communities with high prevalence of GABHS tonsillitis (Hanna 2010). Therefore, studies performed in low-income and high-prevalence communities are needed.

\section{Agreements and disagreements with other studies or reviews}

We found that although there seems to be some benefit of antibiotics with a wider spectrum, such as cephalosporins and carbacephem, this observed effect is not consistent across 
analysis methods and subgroups. Cephalosporins showed benefit regarding resolution of symptoms only in the analysis of evaluable participants, and carbacephem is superior to penicillin for this outcome only in the ITT analysis (attributable to an effect in children treated with a carbacephem). The NNTBs associated with the observed effects were relatively high (20 for treatment with cephalosporins compared with penicillin), except perhaps for the effect of carbacephem in children (NNTB 8.3). There was no clinically meaningful difference between penicillin and the other classes of antibiotics studied with regard to rate of clinical relapse. However, cephalosporins seemed to reduce the relapse rate (NNTB $50)$, especially in adults (NNTB 30).

The effects observed in cephalosporins and carbacephems and not in the other antibiotic classes can be explained by the fact that although they are considered different classes of antibiotics, carbacephems chemically closely resemble cephalosporins (Cooper 1992).

Unpublished study, NCT00643149, concluded that a single dose of azithromycin was superior to 10 days of amoxicillin in children. However, the analysis was based on a per protocol population that had completed at least eight days of treatment. Results were based on those patients who responded bacteriologically, thus censoring patients with strains resistant to the allocated antibiotic. Because eradication rates were higher in the azithromycin arm this may have biased the analysis. The ITT analysis, which underestimates the effect, did not show any difference between groups. In addition, amoxicillin may not be an appropriate choice for the treatment of GABHS pharyngitis/tonsillitis, considering the implications of using wide spectrum antibiotics on resistance in the community.

Interpretation of these findings for clinical practice is not straightforward. One could argue that our meta-analysis points to a superior efficacy of cephalosporins over penicillin, especially in adults where the upper limit of the $95 \%$ confidence interval $(\mathrm{Cl})$ is $1.01(P=0.06)$ in the ITT analysis. The population size may not have been large enough to reach statistical significance. This finding is in line with an earlier review concluding that cephalosporins are superior to penicillin in treating GABHS pharyngitis, and therefore cephalosporins should be considered first choice (Casey 2004). However, in our review the absolute difference between the cephalosporin or penicillin, although not statistically significant, was $2.5 \%$, which implies a NNTB of 40 . Treating 40 patients with cephalosporins instead of penicillin would incur additional costs to healthcare systems and add to the risk of developing antibiotic resistance, especially in broad-spectrum antibiotics such as cephalosporins.

The observed superior effect of cephalosporins in reducing the rate of relapse has been reported elsewhere (Casey 2004). However, in our review it is only observed in adults and may be biased by the rather liberal definition of relapse in the study that accounts for $49 \%$ of weighting in the meta-analysis (Nemeth 1999); "worsening of, or absence of significant remission of, signs and symptoms 17 to 24 days post-therapy or need for further AB therapy", whereas in other studies "recurrence of symptoms" after initial remission was required. The NNTB of 33 participants that need to be treated with cephalosporins rather than penicillin to prevent one participant experiencing relapse illustrates the limited clinical relevance of this statistically significant result.
How can the differences between Casey's meta-analysis and ours be explained? Casey 2004 included 35 trials; two-thirds were not blinded and reporting of randomisation and losses to follow-up was very poor, implying a high risk of bias (Gerber 2004). By restricting inclusion to double-blinded trials we ruled out one source of potential bias and improved methodological rigour. The Casey 2004 subgroup analysis of double-blinded studies generated an OR similar to ours (although with a much narrower Cl: OR $0.43,95 \% \mathrm{Cl}$ 0.25 to 0.71 ), but included studies with carbacephems, which have been advertised as a separate class of antibiotics (Cooper 1992). Casey 2004 reported an analysis of evaluable patients, whereas ITT analysis may be more appropriate especially with important numbers of dropouts (which is the case in many of the trials included in our review). The trial populations included in Casey 2004, as in ours, may have been contaminated with chronic carriers of GABHS who had intercurrent viral pharyngitis (Gerber 2004), but it was not clear if this has implications for clinical practice. Gerber $1999 \mathrm{~b}$ argued that the superior effectiveness of cephalosporins over penicillin observed in some studies may reflect a greater ability to eradicate the streptococcal carrier state rather than actual superior effectiveness of "bona fide acute GABHS pharyngitis".

We found no differences in the incidence of adverse events, and data on long-term follow-up and occurrence of complications were insufficient. Therefore, costs and antimicrobial resistance patterns are important in making treatment choices.

\section{AUTHORS' CONCLUSIONS}

\section{Implications for practice}

Our review did not find clinically important differences in clinical outcomes when different classes of antibiotics were compared with penicillin in adults and children with pharyngitis caused by GABHS. The finding that carbacephems and cephalosporins may have some benefit over penicillin in terms of resolution of symptoms and incidence of relapse was inconsistent across analysis methods (only statistically significant for the evaluable patients analysis) and the NNTB was substantial. This is not compelling evidence to alter current guideline recommendations for treatment of patients with GABHS tonsillopharyngitis. Moreover, we found no clinically important differences in occurrence of adverse events, and data on the incidence of complications were too few to draw conclusions.

Antibiotics have a limited effect in the treatment of patients with acute sore throat, even in the presence of GABHS. However, if antibiotics are to be prescribed, based on these results and taking into consideration the costs and antimicrobial resistance patterns of different antibiotics, penicillin can still be considered a first choice treatment for both adults and children.

\section{Implications for research}

The observed differences in clinical efficacy between adults and children needs further exploration. The currently available studies include different age ranges which makes it difficult to identify differential effects in various age groups. Individual patient data were unavailable; therefore, future studies reporting effects in distinct age groups may provide clinically relevant information. Prevention of serious complications such as acute rheumatic fever and acute glomerulonephritis are often mentioned as arguments in favour of antibiotic use. However, the current data do not provide information about the impact of different antibiotics for prevention 
of complications. Further studies with longer follow-up may be able to address this issue. Because these complications seem to be more prevalent in low-income and high-risk communities (for example, Australian Indigenous communities), studies in these specific high-risk communities are needed. Economic analysis of the cost-effectiveness of different treatment options may provide additional guidance for making treatment choices.

\section{ACK N O WLEDGEMENTS}

We thank the Cochrane Acute Respiratory Infections Group, particularly Liz Dooley and Chris Del Mar, for their support. We thank Warren Mclsaac, Amy Zelmer, Mark Jones, and Paul Little for their valuable comments. For this 2016 update, we thank the following people for commenting on the updated review: Noorin Bhimani, Rashmi Das, Mark Jones and Paul Little.

We also thank Natalja Keber (NK) who assisted with study selection and data extraction for the original version of this review. 


\section{RE F E R E N C E S}

\section{References to studies included in this review}

Bachand 1991 \{published data only\}

Bachand RT Jr. A comparative study of clarythromycin and penicillin VK in the treatment of outpatients with streptococcal pharyngitis. Journal of Antimicrobial Chemotherapy 1991;27(Suppl A):75-82.

\section{Carbon 1995 \{published data only\}}

Carbon C, Chatelin A, Bingen E, Zuck P, Rio Y, Guetat F, et al. A double-blind randomized trial comparing the efficacy and safety of a 5-day course of cefotiam hexetil with that of a 10day course of penicillin $V$ in adult patients with pharyngitis caused by group A beta-haemolytic streptococci. Journal of Antimicrobial Chemotherapy 1995;35(6):843-54.

\section{Disney 1992a \{published data only\}}

Disney FA, Dillon H, Blumer JL, Dudding BA, McLinn SE, Nelson DB, et al. Cephalexin and penicillin in the treatment of group A beta-hemolytic streptococcal throat infections. American Journal of Diseases of Children 1992;146(11):1324-7.

\section{Disney 1992b \{published data only\}}

Disney FA, Hanfling MJ, Hausinger SA. Loracarbef (LY163892) vs. penicillin VK in the treatment of streptococcal pharyngitis and tonsillitis. Pediatric Infectious Disease Journal 1992;11(Suppl 8):20-6.

\section{Henness 1982 \{published data only\}}

Henness DM. A clinical experience with cefadroxil in upper respiratory tract infection. Journal of Antimicrobial Chemotherapy 1982;10(Suppl B):125-35.

\section{Jackson 1973 \{published data only\}}

Jackson H. A comparative study of clindamycin palmitate and ampicillin in the treatment of group $A$ beta hemolytic streptococcal pharyngitis. Clinical Pediatrics 1973;12(8):501-3.

\section{Levenstein 1991 \{published data only\}}

Levenstein JH. Clarythromycin versus penicillin in the treatment of streptococcal pharyngitis. Journal of Antimicrobial Chemotherapy 1991;27(Suppl A):67-74.

\section{McCarty 1992a \{published data only\}}

McCarty J. Loracarbef versus penicillin VK in the treatment of streptococcal pharyngitis and tonsillitis in an adult population. American Journal of Medicine 1992;92(Suppl 6A):74-9.

\section{Muller 1992 \{published data only\}}

Muller O, Spirer Z, Wettich K. Loracarbef versus penicillin V in the treatment of streptococcal pharyngitis and tonsillitis. Infection 1992;20(5):301-8.

\section{NCT00643149 \{unpublished data only\}}

NCT00643149. A multicenter, randomized, double-blind, double-dummy study of azithromycin SR versus amoxicillin for the treatment of strep throat In children. clinicaltrials.gov/ ct2/show/NCT00643149 (first received 19 March 2008). [http:// clinicaltrials.gov/ct2/show/record/NCT00643149]
Nemeth 1999 \{published data only\}

Nemeth MA, McCarty J, Gooch III WM, Henry D, Keyserling CH, Tack KJ. Comparison of cefdinir and penicillin for the treatment of streptococcal pharyngitis. Clinical Therapeutics 1999;21(11):1873-81.

\section{Norrby 2002 \{published data only\}}

Norrby SR, Chang J, Stewart JA, Brumpt I, Conway DP. Relief of symptoms in patients with group $A$ b-hemolytic streptococcus tonsillopharyngitis: comparison between telithromycin and penicillin V. Scandinavian Journal of Infectious Diseases 2003;35(4):223-5

* Norrby SR, Rabie WJ, Bacart P, Mueller O, Leroy B, Rangaraju M, et al. Efficacy of short-course therapy with the ketolide telithromycin compared with 10 days of penicillin $V$ for the treatment of pharyngitis/tonsillitis. Scandinavian Journal of Infectious Diseases 2002;33(12):883-90.

\section{O'Doherty 1996 \{published data only\}}

O'Doherty B, Paediatric Azithromycin Study Group. Azithromycin versus penicillin $\mathrm{V}$ in the treatment of paediatric patients with acute streptococcal pharyngitis/tonsillitis. European Journal of Clinical Microbiology and Infectious Diseases 1996;15(9):718-24

\section{Randolph 1985 \{published data only\}}

Randolph MF, Gerber MA, DeMeo KK, Wright BS. Effect of antibiotic therapy on the clinical course of streptococcal pharyngitis. Journal of Pediatrics 1985;106(6):870-5.

\section{Reed 1991 \{published data only\}}

Reed BD, Huck W, Zazove P. Treatment of beta-hemolytic streptococcal pharyngitis with cefaclor or penicillin; efficacy and interaction with beta-lactamase-producing organisms in the pharynx. Journal of Family Practice 1991;32(2):138-44.

\section{Stein 1991 \{published data only\}}

Stein GE, Christensen S, Mummaw N. Comparative study of clarythromycin and penicillin $\mathrm{V}$ in the treatment of streptococcal pharyngitis. European Journal of Clinical Microbiology and Infectious Diseases 1991;10(11):949-53.

\section{Trickett 1973 \{published data only\}}

Trickett PC, Dineen P, Mogabgab W. Clinical experience: respiratory tract. Trimethoprim-sulfamethoxazole versus penicillin $\mathrm{G}$ in the treatment of group $\mathrm{A}$ beta-hemolytic streptococcal pharyngitis and tonsillitis. Journal of Infectious Diseases 1973;128(Suppl):693-5.

\section{Watkins 1997 \{published data only\}}

Watkins VS, Smietana M, Conforti PM, Sides GD, Huck W. Comparison of dirithromycin and penicillin for treatment of streptococcal pharyngitis. Antimicrobial Agents and Chemotherapy 1997;41(1):72-5. 


\section{References to studies excluded from this review}

Adam 1994 \{published data only\}

Adam D, Hostalek U. Effectiveness and tolerance of cefixime in comparison with penicillin $\mathrm{V}$ in bacterial pharyngitis and tonsillitis in children. Cefixime Study Group. Klinische Padiatrie 1994;206(1):26-9.

\section{Adam 1995 \{published data only\}}

Adam D, Hostalek U, Troster K. 5-day cefixime therapy for bacterial pharyngitis and/or tonsillitis: comparison with 10-day penicillin V therapy. Infection 1995;22(Suppl 2):83-6.

\section{Adam 1996 \{published data only\}}

Adam D, Scholz H, the Pharyngitis Study Group. Five days of erythromycin estolate versus ten days of penicillin $\mathrm{V}$ in the treatment of group A Streptococcal tonsillopharyngitis in children. European Journal of Clinical Microbiology and Infectious Diseases 1996;15(9):712-7.

\section{Adam 2000a \{published data only\}}

Adam D, Scholz H, Helmerking M. Comparison of short-course ( 5 day) cefuroxime axetil with a standard 10 day oral penicillin $\checkmark$ regimen in the treatment of tonsillopharyngitis. Journal of Antimicrobial Chemotherapy 2000;45(Suppl):23-30.

\section{Adam 2000b \{published data only\}}

Adam D, Scholz H, Helmerking M. Short-course antibiotic treatment of 4782 culture-proven cases of group A streptococcal tonsillopharyngitis and incidence of poststreptococcal sequelae. Journal of Infectious Diseases 2000;182(2):509-16.

\section{Adam 2001 \{published data only\}}

Adam D, Scholz H, Helmerking M. Five days ceftibuten versus 10 days penicillin in the treatment of 2099 patients with Astreptococcal tonsillopharyngitis [Fünf Tage Ceftibuten im Vergleich zu zehn Tagen Penicillin V in der Therapie der AStreptokokken-Tonsillopharyngitis]. Fortschritte der Medizin 2001;119(Suppl 2):63-70.

\section{Aujard 1995 \{published data only\}}

Aujard Y, Boucot I, Brahimi N, Chiche D, Bingen E. Comparative efficacy and safety of four-day cefuroxime axetil and ten-day penicillin treatment of group A beta-hemolytic streptococcal pharyngitis in children. Pediatric Infectious Disease Journal 1995;14(4):295-300.

\section{Bottaro 2012 \{published data only\}}

Bottaro G, Biasci P, Giudice MLO, Mele G, Montanari G, Napoleone E, et al. 5 days cefaclor vs. 10 days amoxicillin/ clavulanate in the treatment of childhood streptococcal pharyngitis. Data from a randomized clinical trial. Minerva Pediatrica 2012;64(3):341-6.

\section{Breese 1974 \{published data only\}}

Breese BB, Disney FA, Talpey WB, Green JL. Treatment of streptococcal pharyngitis with amoxicillin. Journal of Infectious Diseases 1974;129(Suppl):178-80.

\section{Cohen 2002 \{published data only\}}

Cohen R, Reinert P, De La Rocque F, Levy C, Boucherat M, Robert M, et al. Comparison of two dosages of azithromycin for three days versus penicillin $V$ for ten days in acute group $A$ streptococcal tonsillopharyngitis. Pediatric Infectious Disease Journal 2002;21:297-303.

\section{Cruz 2011 \{published data only\}}

Llerena Santa Cruz ED, Buñuel Álvarez JC, Porcar Farrán D, Solà Pou J, Fortea Gimeno E, Cortés Marina RB, et al. Treatment of streptococcal tonsillitis with once-aday amoxicillin: a meta-analysis. Anales De Pediatria 2011;75(5):298-306.

Davies 1995 \{published data only\}

Davies HD, Low DE, Schwartz B, Scriver S, Fletcher A, O'Rourke K, et al. Evaluation of short-course therapy with cefixime or rifampin for eradication of pharyngeally carried group A Streptococci. Clinical Infectious Diseases 1995;21:1294-6.

\section{Del Mar 2008 \{published data only\}}

Del Mar C. Once-daily amoxycillin eradicates group A betahemolytic strep as well as penicillin twice a day. Journal of Pediatrics 2008;153(5):725.

\section{De Meyere 1992 \{published data only\}}

de Meyere M, Mervielde I, Bogaert M. Use of antibiotics in acute sore throat [Het nut van antibiotica bij acute keelpijn]. Nederlands Tijdschrift Voor Geneeskunde 1992;136(47):2314-7.

Denny 1953 \{published data only\}

Denny FW, Wannamaker LW, Hahn EO. Comparative effects of penicillin, aureomycin and terramycin on streptococcal tonsillitis and pharyngitis. Pediatric Infectious Disease 1953;11:7-14.

\section{Disney 1979 \{published data only\}}

Disney FA, Breese BB, Francis AB, Green JL. The use of cefaclor in the treatment of beta-haemolytic streptococcal throat infections in children. Postgraduate Medical Journal 1979;55(Suppl 4):50-2.

Dykhuizen 1996 \{published data only\}

Dykhuizen RS, Golder D, Reid TMS, Gould IM. Phenoxymethyl penicillin versus co-amoxiclav in the treatment of acute streptococcal pharyngitis, and the role of beta-lactamase activity in saliva. Journal of Antimicrobial Chemotherapy 1996;37:133-8.

\section{Esposito 2002 \{published data only\}}

Esposito S, Marchisio P, Bosis S, Droghetti R, Mattina R, Principi N, et al. Comparative efficacy and safety of 5day cefaclor and 10-day amoxycillin treatment of group A streptococcal pharyngitis in children. International Journal of Antimicrobial Agents 2002;20:28-33.

\section{Feder 1999 \{published data only\}}

Feder HM Jr, Gerber MA, Randolph MF, Stelmach PS, Kaplan EL. Once-daily therapy for streptococcal pharyngitis with amoxicillin. Pediatrics 1999;103:47-51. 


\section{Gerber 1986 \{published data only\}}

Gerber MA, Randolph MF, Chanatry J, Wright LL, Anderson LR, Kaplan EL. Once daily therapy for streptococcal pharyngitis with cefadroxil. Journal of Pediatrics 1986;109(3):531-7.

\section{Gerber 1999a \{published data only\}}

Gerber MA, Tanz RR, Kabat W, Bell GL, Siddiqui PN, Lerer TJ, et al. Potential mechanisms for failure to eradicate group $\mathrm{A}$ streptococci from the pharynx. Pediatrics 1999;104(4):911-7.

\section{Gooch 1993 \{published data only\}}

Gooch WM 3rd, McLinn SE, Arnovitz GH, Pichichero ME, Kumar A, Kaplan A, et al. Efficacy of cefuroxime axetil suspension compared with that of penicillin $V$ suspension in children with group A streptococcal pharyngitis. Antimicrobial Agents and Chemotherapy 1993;37(2):159-63.

\section{Granizio 2008 \{published data only\}}

Granizio JJ, Gimenez MJ, Barberan J, Coronel J, Gimeno M, Aguilar L. Efficacy of cefditoren in the treatment of upper respiratory tract infections: a pooled analysis of six clinical trials. Revista Espanola de Quimioterapia 2008;21(1):14-21.

\section{Hamill 1993 \{published data only\}}

Hamill J. Multicentre evaluation of azithromycin and penicillin $\mathrm{V}$ in the treatment of acute streptococcal pharyngitis and tonsillitis in children. Journal of Antimicrobial Chemotherapy 1993;31(Suppl E):89-94.

\section{Haverkorn 1971 \{published data only\}}

Haverkorn MJ, Valkenburg HA, Goslings WR. Streptococcal pharyngitis in the general population. I. A controlled study of streptococcal pharyngitis and its complications in the Netherlands. Journal of Infectious Diseases 1971;124(4):339-47.

\section{Holm 1991 \{published data only\}}

Holm SE, Roos K, Stromberg A. A randomized study of treatment of streptococcal pharyngotonsillitis with cefadroxil or phenoxymethylpenicillin (penicillin V). Pediatric Infectious Disease Journal 1991;10(Suppl 10):68-71.

\section{Howe 1997 \{published data only\}}

Howe RW, Millar MR, Coast J, Whitfield M, Peters TJ, Brookes S. A randomized controlled trial of antibiotics on symptom resolution in patients presenting to their general practitioner with a sore throat. British Journal of General Practice 1997;47:280-4

\section{Kuroki 2013 \{published data only\}}

Kuroki H, Ishiwada N, Inoue N, Ishikawa N, Suzuki H, Himi K, et al. Comparison of clinical efficacy between 3-day combined clavulanate/amoxicillin preparation treatment and 10-day amoxicillin treatment in children with pharyngolaryngitis or tonsillitis. Journal of Infection and Chemotherapy 2013;19:12-9.

\section{Lennon 2008 \{published data only\}}

Lennon DR, Farrell E, Martin DR, Stewart JM. Once-daily amoxicillin versus twice-daily penicillin $\mathrm{V}$ in group $\mathrm{A}$ betahemolytic streptococcal pharyngitis. Archives of Disease in Childhood 2008;93(6):474-8.

\section{Matsen 1974 \{published data only\}}

Matsen JM, Torstenson O, Siegel SE, Bacaner H. Use of available dosage forms of cephalexin in clinical comparison with phenoxymethyl penicillin and benzathine penicillin in the treatment of streptococcal pharyngitis in children. Antimicrobial Agents and Chemotherapy 1974;6(4):501-6.

McCarty 1992b \{published data only\}

McCarty JM, Renteria A. Treatment of pharyngitis and tonsillitis with cefprozil: review of three multicenter trials. Clinical Infectious Diseases 1992;14(Suppl 2):224-30.

McCarty 1994 \{published data only\} McCarty JM. Comparative efficacy and safety of cefprozil versus penicillin, cefaclor and erythromycin in the treatment of streptococcal pharyngitis and tonsillitis. European Journal of Clinical Microbiology and Infectious Diseases 1994;13(10):846-50.

\section{Mclsaac 2004 \{published data only\}}

Mclsaac WJ, Kellner JD, Aufricht P, Vanjaka A, Low DE. Empirical validation of guidelines for the management of pharyngitis in children and adults. JAMA 2004;291(13):1587-95.

Milatovic 1991 \{published data only\}

Milatovic D. Evaluation of cefadroxil, penicillin and erythromycin in the treatment of streptococcal tonsillopharyngitis. Pediatric Infectious Disease Journal 1991;10(Suppl):61-3.

\section{Milatovic 1993 \{published data only\}}

Milatovic D, Adam D, Hamilton H, Materman E. Cefprozi versus penicillin $\mathrm{V}$ in the treatment of streptococcal tonsillopharyngitis. Antimicrobial Agents and Chemotherapy 1993;37(8):1620-3.

\section{NCT00393744 \{published and unpublished data\}}

NCT00393744. Efficacy study of pristinamycin versus amoxicillin to treat tonsillitis induced by streptococcus in children. clinicaltrials.gov/ct2/show/NCT00393744 (first received 27 October 2006). [http://clinicaltrials.gov/ct2/show/record/ NCT00393744]

\section{Pacifico 1996 \{published data only\}}

Pacifico L, Scopetti F, Ranucci A, Pataracchia M, Savignoni F, Chiesa C. Comparative efficacy and safety of 3-day azithromycin and 10-day penicillin $\mathrm{V}$ treatment of group $\mathrm{A}$ beta-hemolytic streptococcal pharyngitis in children. Antimicrobial Agents and Chemotherapy 1996;40(4):1005-8.

Perkins 1969 \{published data only\}

Perkins RL, Glontz GE, Saslaw S. Cephaloglycin: crossover absorption studies and clinical evaluation. Clinical Pharmacology and Therapeutics 1969;10(2):244-9.

Pichichero 2000 \{published data only\}

Pichichero ME, Gooch WM 3rd. Comparison of cefdinir and penicillin $\mathrm{V}$ in the treatment of pediatric streptococcal tonsillopharyngitis. Pediatric Infectious Disease Journal 2000;19(Suppl 12):171-3. 
Pichichero 2008 \{published data only\}

Pichichero ME, Casey JR, Block SL, Guttendorf R, Flanner H, Markowitz D, et al. Pharmacodynamic analysis and clinical trial of amoxicillin sprinkle administered once daily for 7 days compared to penicillin v potassium administered four times daily for 10 days in the treatment of tonsillopharyngitis due to streptococcus pyogenes in children. Antimicrobial Agents and Chemotherapy 2008;52(7):2512-20.

Portier 1990 \{published data only\}

Portier H, Chavanet P, Gouyon JB, Guetat F. Five day treatment of pharyngotonsillitis with cefpodoxime proxetil. Journal of Antimicrobial Chemotherapy 1990;26(Suppl E):79-85.

Portier 1994 \{published data only\}

Portier H, Chavanet P, Waldner-Combernoux A, Kisterman JP, Grey PC, Ichou F, et al. Five versus ten days treatment of Streptococcal pharyngotonsillitis: a randomized controlled trial comparing cefpodoxime proxetil and phenoxymethyl penicillin. Scandinavian Journal of Infectious Diseases 1994;26(1):59-66.

Rimoin 2011 \{published data only\}

Rimoin AW, Hoff NA, Fischer Walker CL, Hamza HS, Vince A, Abdel Rahman N, et al. Treatment of streptococcal pharyngitis with once-daily amoxicillin versus intramuscular benzathine penicillin $\mathrm{G}$ in low-resource settings: a randomized controlled trial. Clinical Pediatrics 2011;50(6):535-42.

\section{Roos 1997 \{published data only\}}

Roos K, Larsson P. Loracarbef versus phenoxymethylpenicillin in the treatment of recurrent streptococcal pharyngotonsillitis. Scandinavian Journal of Infectious Diseases 1997;29(2):141-5.

\section{Sakata 2008 \{published data only\}}

Sakata H. Comparative study of 5-day cefcapene-pivoxil and 10day amoxicillin or cefcapene-pivoxil for treatment of group A streptococcal pharyngitis in children. Journal of Infection and Chemotherapy 2008;14(3):208-12.

\section{Shapera 1973 \{published data only\}}

Shapera RM, Hable KA, Matsen JM. Erythromycin therapy twice daily for streptococcal pharyngitis. Controlled comparison with erythromycin or penicillin phenoxymethyl four times daily or penicillin G benzathine. JAMA 1973;226(5):531-5.

\section{Shvartzman 1993 \{published data only\}}

Shvartzman P, Tabenkin H, Rosentzwaig A, Dolginov F. Treatment of streptococcal pharyngitis with amoxycillin once a day. BMJ 1993;306(6886):1170-2.

\section{Siegel 1961 \{published data only\}}

Siegel AC, Johnson EE, Stollerman GH. Controlled studies of streptococcal pharyngitis in a pediatric population. New England Journal of Medicine 1961;265(12):559-65.

\section{Standaert 1997 \{published data only\}}

Standaert BB, Finney KMA, Taylor MT, Coleman RT, Horowitz CL, Walter SM, et al. Comparison between cefprozil and penicillin to eradicate pharyngeal colonization of group A betahemolytic streptococci. Pediatric Infectious Disease Journal 1998;17(1):39-43.

\section{Stelter 2014 \{published data only\}}

Stelter K. Tonsillitis and sore throat in childhood. Laryngologie, Rhinologie, Otologie 2014;93(Suppl):84-102.

Stillerman 1970 \{published data only\}

Stillerman M. Comparison of cephaloglycin and penicillin in streptococcal pharyngitis. Clinical Pharmacology and Therapeutics 1970;11(2):205-12.

Stillerman 1986 \{published data only\}

Stillerman M. Comparison of oral cephalosporins with penicillin therapy for group A streptococcal pharyngitis. Pediatric Infectious Disease Journal 1986;5(6):649-54

\section{Tack 1997 \{published data only\}}

Tack KJ, Hendrick JA, Rothstein E, Nemeth MA, Keyserling C, Pichichero ME. A study of 5-day treatment for streptococcal pharyngitis in children. Cefdinir Pediatric Study Group. Archives of Pediatric and Adolescent Medicine 1997;151(1):45-9.

\section{Tack 1998 \{published data only\}}

Tack KJ, Henry DC, Gooch WM, Brink DN, Keyserling CH, the Cefdinir Pharyngitis Study Group. Five-day cefdinir treatment for streptococcal pharyngitis. Antimicrobial Agents and Chemotherapy 1998;42(5):1073-5.

Uysal 2000 \{published data only\}

Uysal S, Sanack R, Sunbul M. A comparison of the efficacy of cefuroxime axetil and intramuscular benzathine penicillin for treating streptococcal tonsillopharyngitis. Annals of Tropical Paediatrics 2000;20:199-202.

\section{Van Brusselen 2014 \{published data only\}}

Van Brusselen D, Vlieghe E, Schelstraete P, De Meulder F, Vandeputte C, Garmyn K, et al. Sterptococcal pharyngitis in children: to treat or not to treat?. European Journal of Paediatrics 2014;173(10):1275-83.

\section{Zwart 2000 \{published data only\}}

Zwart S, Sachs APE, Ruijs GJHM, Gubbels JW, Hoes AW, de Melker RA. Penicillin for acute sore throat: randomised double blind trial of seven days versus three days treatment or placebo in adults. BMJ 2000;320(7228):150-4.

\section{References to studies awaiting assessment}

Eslami 2014 \{published data only\}

Eslami ST, Nassirian A, Nassirian H, Hatami E, Sobhani E, Najibpour R. Comparing performance of amoxicillin and intramuscular benzathine penicillin in relieving manifestations of streptococcal pharyngitis in children. Ghana Medical Journal 2014;48(4):185-8.

\section{Additional references}

\section{Albin 2014}

Albin S, Agarwal S. Prevalence and characteristics of reported penicillin allergy in an urban outpatient adult population. Allergy Asthma Proc doi: 10.2500/aap.2014.35.3791 2014;35:489 94. [DOI: 10.2500/aap.2014.35.3791] 


\section{Atkins 2004}

Atkins D, Best D, Briss PA, Eccles M, Falck-Ytter Y, Flottorp S, et al. GRADE Working Group. Grading quality of evidence and strength of recommendations. BMJ 2004;328(7454):1490.

\section{Battacharya 2010}

Bhattacharya S. The facts about penicillin allergy: a review. $J$ Adv Pharm Technol Res 2010;1(1):11-7.

\section{Brunton 2006}

Brunton S, Pichichero M. Considerations in the use of antibiotics for streptococcal pharyngitis. Journal of Family Practice 2006;55(Suppl 7):9-16.

\section{Cars 2001}

Cars O, Mölstad S, Melander A. Variation in antibiotic use in the European Union. Lancet 2001;357(9271):1851-3.

\section{Casey 2004}

Casey JR, Pichichero ME. Meta-analysis of cephalosporin versus penicillin treatment of group A streptococcal tonsillopharyngitis in children. Pediatrics 2004;113:866-82.

\section{Cooper 1992}

Cooper RD. The carbacephems: a new beta-lactam antibiotic class. American Journal of Medicine 1992;92(Suppl):2-6.

\section{Cooper 2001}

Cooper RJ, Hoffman JR, Bartlett JG, Besser JG, Gonzales R, Hickner JM, et al. Principles of appropriate antibiotic use for acute pharyngitis in adults: background. Annals of Internal Medicine 2001;134(6):509-17.

\section{DerSimonian 1986}

DerSimonian R, Laird N. Meta-analysis in clinical trials. Controlled Clinical Trials 1986;7(3):177-88.

\section{Devi 2011}

Devi U, Borah PK, Mahanta J. The prevalence and antimicrobial susceptibility patterns of beta-hemolytic streptococci colonizing the throats of schoolchildren in Assam, India. Journal of Infection in Developing Countries 2011;5(11):804-8.

\section{Gerber 1999b}

Gerber MA, Tanz RR, Kabat W, Bell GL, Lerer TJ, Lepow ML, et al. Potential mechanisms for failure to eradicate group $A$ streptococci from the pharynx. Pediatrics 1999;104:911-7.

\section{Gerber 2004}

Gerber MA, Shulman ST. Rapid diagnosis of pharyngitis caused by group A streptococci. Clinical Microbiology Reviews 2004;17(3):571-80

\section{Gerber 2009b}

Gerber MA, Baltimore RS, Eaton CB, Gewitz MSM, Rowley AH, Shulman ST, et al. Prevention of rheumatic fever and diagnosis and treatment of acute Streptococcal pharyngitis. A scientific statement from the American Heart Association Rheumatic Fever, Endocarditis, and Kawasaki Disease Committee of the Council on Cardiovascular Disease in the Young, the Interdisciplinary Council on Functional Genomics and
Translational Biology, and the Interdisciplinary Council on Quality of Care and Outcomes Research. Circulation 2009;119(11):1541.

\section{GRADEproGDT 2014 [Computer program]}

GRADE Working Group, McMaster University. GRADEproGDT. Version accessed 2016. Hamilton (ON): GRADE Working Group, McMaster University, 2014. [www.gradepro.org]

\section{Hanna 2010}

Hanna J, Clark MF. Acute rheumatic fever in Indigenous people in North Queensland: some good news at last?. Medical Journal of Australia 2010;192(10):581-4.

\section{Higgins 2003}

Higgins JPT, Thompson SG, Deeks JJ, Altman DJ. Measuring inconsistency in meta-analyses. BMJ 2003;327(7414):557-60. [DOI: 10.1136/bmj.327.7414.557]

\section{Higgins 2011}

Higgins JP, Green S, editors. Cochrane Handbook for Systematic Reviews of Interventions Version 5.1.0 (updated March 2011). The Cochrane Collaboration, 2011. Available from handbook.cochrane.org.

\section{Ibrahim 2014}

Ibrahim SB, El-Sokkary RH, Elhewala AA, El-Anwar MW, Awad WM, Hamed AM, et al. Emerging resistance to erythromycin and penicillin among streptococcus pyogenes isolates in Zagazig, Egypt. International Journal of Current Microbiology and Applied Sciences 2014;3(10):750-6.

\section{Lefebvre 2011}

Lefebvre C, Manheimer E, Glanville J. Chapter 6: Searching for studies. In: Higgins JP, Green S, editors. Cochrane Handbook for Systematic Reviews of Interventions Version 5.1.0 (updated March 2011). The Cochrane Collaboration, 2011. Available from www.handbook.cochrane.org.

\section{Linder 2001}

Linder JA, Stafford RS. Antibiotic treatment of adults with sore throat by community primary care physicians. A National Survey, 1989-1999. JAMA 2001;286(10):1181-6.

\section{Mantel 1959}

Mantel N, Haenszel W. Statistical aspects of the analysis of data from retrospective studies of disease. Journal of the National Cancer Institute 1959;22:719-48.

\section{Matthys 2007}

Matthys J, De Meyere M, van Driel ML, De Sutter A. Differences among international pharyngitis guidelines: not just academic. Annals of Family Medicine 2007;5:436-43. [DOI: 10.1370/afm.741]

\section{Mclsaac 1998}

Mclsaac WJ, White D, Tannenbaum D, Low DE. A clinical score to reduce unnecessary antibiotic use in patients with sore throat. Canadian Medical Association Journal 1998;158:75-83. 


\section{Moher 2009}

Moher D, Liberati A, Tetzlaff J, Altman DG, The PRISMA Group. Preferred reporting items for systematic reviews and metaanalyses: The PRISMA Statement. BMJ 2009;339:2535.

\section{Neuner 2003}

Neuner JM, Hamel MB, Phillips RS, Bona K, Aronson MD. Diagnosis and management of adults with pharyngitis: a cost-effectiveness analysis. Annals of Internal Medicine 2003;139(2):113-22.

\section{RevMan 2014 [Computer program]}

Nordic Cochrane Centre, The Cochrane Collaboration. Review Manager (RevMan). Version 5.3. Copenhagen: Nordic Cochrane Centre, The Cochrane Collaboration, 2014.

\section{Shulman 2004}

Shulman ST, Gerber MA. So what's wrong with penicillin for strep throat?. Pediatrics 2004;113:1816-9. [DOI: 10.1542/ peds.113.6.1816]

\section{Snow 2001}

Snow V, Mottur-Pilson C, Cooper RJ, Hoffman JR. Principles of appropriate antibiotic use for acute pharyngitis in adults. Annals of Internal Medicine 2001;134(6):506-8.

\section{Sonnad 1999}

Sonnad SS, Zarkower N, Varney G. Rapid antigen testing for group A beta-hemolytic Streptococcus: a metaanalysis evaluation of test performance (Meeting Abstract). Annual Meeting of the International Society of Technology Assessment in Health Care 1999;15:122. [PUBMED: http:// gateway.nlm.nih.gov/MeetingAbstracts/ma?f=102194100.html]

\section{Spinks 2013}

Spinks A, Glasziou PP, Del Mar CB. Antibiotics for sore throat. Cochrane Database of Systematic Reviews 2013, Issue 11. [DOI: 10.1002/14651858.CD000023.pub4]

\section{CHARACTERISTICS OF STUDIES}

Characteristics of included studies [ordered by study ID]

\section{van Driel 2006}

van Driel ML, De Sutter A, Deveugele M, Peersman W, Butler CC, De Meyere M, De Maeseneer J, Christiaens T. Are sore throat patients who hope for antibiotics actually asking for pain relief?. Ann Fam Med 2006;4:494-9.

\section{van Driel 2009}

van Driel ML, De Sutter A, De Maeseneer J, Christiaens T. Searching for unpublished trials in Cochrane reviews may not be worth the effort. Journal of Clinical Epidemiology 2009;62(8):838-44.

\section{Wise 1998}

Wise R, Hart T, Cars O, Streulens M, Helmuth R, Huovinen P, et al. Antimicrobial resistance. Is a major threat to public health. BMJ 1998;317(7159):609-10.

\section{Worrall 2007}

Worrall GJ. Acute sore throat. Canadian Family Physician 2007;53:1961-2.

\section{References to other published versions of this review van Driel 2003}

van Driel ML, De Sutter AIM, Keber N, Habraken H, Christiaens T. Different antibiotic treatments for group A streptococcal pharyngitis. Cochrane Database of Systematic Reviews 2003, Issue 3. [DOI: 10.1002/14651858.CD004406]

\section{van Driel 2010}

van Driel ML, De Sutter AIM, Keber N, Habraken H, Christiaens T. Different antibiotic treatments for group A streptococcal pharyngitis. Cochrane Database of Systematic Reviews 2010, Issue 10. [DOI: 10.1002/14651858.CD004406.pub2]

* Indicates the major publication for the study

Bachand 1991

\begin{tabular}{ll} 
Methods & - RCT, randomised 1:1 \\
& - Double-blinded \\
& - Double-dummy \\
\hline Participants & - Number of randomised participants: 128 (108 S. pyogenes positive) \\
& - Number of participants evaluated: 90 \\
& - Number of dropouts: 38 (29.7\%) \\
& - Setting: 17 clinical centres US \\
& - Age: 12 to 62 years \\
& - Diagnosis: rapid immunoassay test, throat culture \\
& - Inclusion criteria: confirmed GABHS pharyngitis \\
& - Exclusion criteria: risk for pregnancy or lactation, weight < 34 kg, no sore throat with at least one sign \\
& of streptococcal pharyngitis, negative rapid immunoassay test, overall poor health, hypersensitivity to \\
& erythromycin or penicillin, renal impairment or hepatic disease, history of rheumatic fever or cardiac \\
& valvular disease, rash suggestive of scarlet fever, active eye inflammation, treated with systemic antibi-
\end{tabular}


Bachand 1991 (Continued)

otic within 2 weeks/an investigational drug within four weeks/long-acting injectable penicillin within six weeks prior to trial, concurrent antimicrobial agents

\begin{tabular}{ll}
\hline Interventions & - Groups: clarithromycin, $250 \mathrm{mg}(2 \times 125 \mathrm{mg})$ caps 12-hourly ( $\mathrm{n}=65)$; penicillin VK $250 \mathrm{mg}(2 \times 125 \mathrm{mg})$ \\
& caps 6-hourly ( $\mathrm{n}=63)$ \\
& - Duration of therapy: $80 \%>10$ days \\
& - Duration of follow-up: 15 to 56 days \\
\hline Outcomes & - Clinical outcomes at 2 to 10 days post-treatment: cure (pre-treatment signs and symptoms resolved \\
& and pathogen eradicated); improvement (pre-treatment signs and symptoms improved but not re- \\
& solved); failure (pre-treatment signs and symptoms not improved or worsened and pathogen persist- \\
& ed); indeterminate (response could not be assigned); relapse/recurrence (pre-treatment signs and \\
& symptoms resolved but reappeared and pathogen recurred) \\
& - Relapse at 15 to 56 days post-treatment \\
& - Adverse effects \\
& - Bacteriological outcomes \\
& - Serology \\
\hline Notes & - Funding: not reported, but author is employee of Abbott International Ltd. \\
- Ethics approval: "the protocol was approved by local ethics committees" \\
- No ITT for efficacy reported \\
- No ITT reported
\end{tabular}

\section{Risk of bias}

Bias Authors' judgement Support for judgement

Random sequence genera- Unclear risk Reported as "randomised (1:1)". Not described how sequence was generated. tion (selection bias)

\begin{tabular}{lll}
$\begin{array}{l}\text { Allocation concealment } \\
\text { (selection bias) }\end{array}$ & Unclear risk & Not described. \\
\hline $\begin{array}{l}\text { Blinding (performance } \\
\text { bias and detection bias) } \\
\text { All outcomes }\end{array}$ & Low risk & "To maintain the double-blind nature of the study, placebos were adminis- \\
\end{tabular}

\begin{tabular}{ll}
\hline $\begin{array}{l}\text { Incomplete outcome data } \\
\text { (attrition bias) }\end{array}$ & High risk \\
All outcomes & $\begin{array}{l}26 \text { participants prematurely discontinued and } 38 \text { were excluded from efficacy } \\
\text { analysis (reasons reported). }\end{array}$ \\
& $29.7 \%$ post-randomisation dropout \\
& No ITT analysis (128 randomised and 90 included in efficacy analysis).
\end{tabular}

\begin{tabular}{lll}
\hline $\begin{array}{l}\text { Selective reporting (re- } \\
\text { porting bias) }\end{array}$ & Unclear risk & "There was no evidence of investigator bias in any of the analyses." \\
\hline Other bias & High risk & Funding: not reported, but author is employee of Abbott International Ltd. \\
\hline
\end{tabular}

\begin{tabular}{ll} 
Carbon 1995 & \\
\hline Methods & - RCT \\
& - Double-blinded \\
& - Double-dummy \\
\hline Participants & - Number of participants enrolled: 250 \\
& - Number of participants randomised: 240 \\
& - Number of participants evaluated: 236
\end{tabular}


Carbon 1995 (Continued)
- Number of dropouts: 4 (2\%)
- Setting: 60 French General Practice clinics
- Age: > 15 yrs
- Diagnosis: rapid antigen test, throat culture
- Inclusion criteria: fever $=/>38^{\circ} \mathrm{C}$, odynophagia, erythema or purulent exudate of pharynx, at least one tender submaxillary lymph node, rapid antigen test positive for GABHS, followed by positive throat cul- ture
- Exclusion criteria: allergy to beta-lactams, pregnancy, lactation, chronic tonsillitis, antibiotics in 5 days preceding randomisation, no written consent

\begin{tabular}{ll} 
Interventions & - Groups: cefotiam hexetil (CTM), 200 mg twice a day for 5 days and a penicillin V (PEV)-like placebo \\
& three times a day for 10 days $(n=119) ;$ penicillin V (PEV) megaunit $(600 \mathrm{mg})$ three times a day for 10 \\
& days and CTM-like placebo twice a day for 5 days ( $\mathrm{n}=125)$ \\
& - Duration of treatment: 15 days \\
& - Duration of follow-up: 90 days \\
\hline Outcomes & - Clinical outcomes: success = cure (complete resolution of fever and symptoms) on days 10 and 30 or \\
& improvement on day 10 and cure on day 30 without further antibiotics) \\
& - Failure = no response to therapy on day 10 , or improvement on day 10 but required further antibiotic \\
& or relapsed (recurrence of fever and/or symptoms), or cured on day 10 but subsequent relapse \\
& - Relapse assessed on day 90 \\
& - Adverse effects \\
- Bacteriological outcomes
\end{tabular}

\begin{tabular}{ll}
\hline Notes & - Funding: not reported \\
& - Ethics approval: not mentioned \\
& - Described as ITT analysis for efficacy, but post-randomisation exclusions not included in analyses \\
\hline
\end{tabular}

\section{Risk of bias}

\begin{tabular}{lll}
\hline Bias & Authors' judgement & Support for judgement \\
\hline $\begin{array}{l}\text { Random sequence genera- } \\
\text { tion (selection bias) }\end{array}$ & Unclear risk & Reported as "randomised", but no description of randomisation sequence. \\
\hline $\begin{array}{l}\text { Allocation concealment } \\
\text { (selection bias) }\end{array}$ & Unclear risk & Not described. \\
\hline $\begin{array}{l}\text { Blinding (performance } \\
\text { bias and detection bias) } \\
\text { All outcomes }\end{array}$ & Unclear risk & $\begin{array}{l}\text { Reported as "double blind, double dummy", but no description of how blind- } \\
\text { ing of different administration frequency and duration was maintained. }\end{array}$ \\
\hline $\begin{array}{l}\text { Incomplete outcome data } \\
\text { (attrition bias) }\end{array}$ & Low risk & $\begin{array}{l}\text { Dropouts: 4 lost to follow-up (all in penicillin group). } \\
\text { All outcomes }\end{array}$ \\
\hline $\begin{array}{l}\text { Selective reporting (re- } \\
\text { porting bias) }\end{array}$ & Unclear risk & $\begin{array}{l}\text { no ITT analysis (although reported in table that ITT, the numbers do not corre- } \\
\text { spond to ITT). }\end{array}$ \\
\hline $\begin{array}{l}\text { Other bias } \\
\text { Only clinical success reported, no specific symptoms; }\end{array}$ & $\begin{array}{l}\text { Adverse events reported, but no ITT analysis. 3 participants in each group dis- } \\
\text { continued because of adverse events. }\end{array}$ \\
\hline
\end{tabular}

Disney 1992a

Methods - RCT


Disney 1992a (Continued)

- Double-blinded

\begin{tabular}{ll}
\hline Participants & - Number of participants eligible: 654 \\
& - Number of participants randomised: 525 \\
& - Number of participants evaluated: 525 \\
& - Number of dropouts: not specified \\
& - Setting: 7 paediatric practices in US \\
& - Age: 4 to 17 yrs \\
& - Diagnosis: clinical tonsillitis or pharyngitis, throat cultures \\
& - Inclusion criteria: clinical tonsillopharyngitis and throat cultures strongly positive for GABHS \\
& - Exclusion criteria: concurrent enrolment of siblings, 2 or more sore throats in previous 6 months, \\
& treated with antibiotic in previous 2 weeks, throat culture negative for GABHS
\end{tabular}

\begin{tabular}{ll}
\hline Interventions & - Groups: cephalexin $27 \mathrm{mg} / \mathrm{kg} 4$ times per day $(\mathrm{n}=263) ;$ penicillin $27 \mathrm{mg} / \mathrm{kg} 4$ times per day $(\mathrm{n}=262)$ \\
& - Duration of treatment: 10 days \\
& - Duration of follow-up: 32 to 35 days
\end{tabular}

\begin{tabular}{ll}
\hline Outcomes & - Clinical outcomes: clinical failure (not defined) at 32 to 35 days \\
& - Clinical relapse (new infection with different serotype) \\
& - Bacteriological outcomes \\
& - Antistreptolysin-O titres \\
- Anti-DNase B titres \\
\hline Notes & - Funding: grant from Lilly Research Laboratories, Indianapolis, Ind., US \\
& - Ethics approval: not mentioned \\
& - ITT analysis on 525 participants completing the protocol, no information on dropouts
\end{tabular}

\section{Risk of bias}

\begin{tabular}{|c|c|c|}
\hline Bias & Authors' judgement & Support for judgement \\
\hline $\begin{array}{l}\text { Random sequence genera- } \\
\text { tion (selection bias) }\end{array}$ & Unclear risk & Reported as "randomised", but no description of randomisation sequence. \\
\hline $\begin{array}{l}\text { Allocation concealment } \\
\text { (selection bias) }\end{array}$ & Unclear risk & $\begin{array}{l}\text { "The participants were assigned...on a random schedule supplied by Eli Lilly } \\
\text { and Co." }\end{array}$ \\
\hline $\begin{array}{l}\text { Blinding (performance } \\
\text { bias and detection bias) } \\
\text { All outcomes }\end{array}$ & Low risk & $\begin{array}{l}\text { "...the physician and parents were not appraised as to who was in which } \\
\text { group." }\end{array}$ \\
\hline $\begin{array}{l}\text { Incomplete outcome data } \\
\text { (attrition bias) } \\
\text { All outcomes }\end{array}$ & Low risk & $\begin{array}{l}\text { No description of dropouts, } 525 \text { of } 525 \text { randomised patients reported } \\
\text { ITT analysis for clinical outcome. }\end{array}$ \\
\hline $\begin{array}{l}\text { Selective reporting (re- } \\
\text { porting bias) }\end{array}$ & Unclear risk & $\begin{array}{l}\text { Only clinical (and bacteriological) failure reported, no symptoms specified. } \\
\text { No reporting of adverse events. }\end{array}$ \\
\hline Other bias & High risk & Funding: grant from Lilly Research Laboratories, Indianapolis, Ind., US \\
\hline
\end{tabular}

\section{Disney 1992b}

\begin{tabular}{ll}
\hline Methods & - RCT, randomised 1:1 \\
& - Double-blinded \\
& - Double-dummy \\
\hline Participants & - Number of participants enrolled: 233 (19 negative culture) \\
\hline
\end{tabular}


Disney 1992b (Continued)

- Number of evaluated participants: 192

- Number of dropouts: 31 (13\%)

- Setting: 11 paediatric offices in US

- Age: 6 months to 12 years

- Diagnosis: rapid antigen test, throat culture

- Inclusion criteria: clinical diagnosis of acute streptococcal pharyngitis/tonsillitis, inflammation and swelling, with or without fever $=>38^{\circ} \mathrm{C}$ or exudate, rapid antigen test or throat culture positive for GAB-

HS, history of compliance

- Exclusion criteria: history of renal impairment (serum creatinine $\geq 177 \mu \mathrm{mol} / \mathrm{L}, 2.0 \mathrm{mg} / \mathrm{dL}$ ), any con-

dition that could preclude evaluation of response, requirement for systemic antibiotic, any antibiotic

therapy within 3 days of start, hypersensitivity to penicillins and/or cephalosporins

\begin{tabular}{ll}
\hline Interventions & - Groups: loracarbef oral suspension, $15 \mathrm{mg} / \mathrm{kg} /$ day 2 divided doses, or $200 \mathrm{mg}$ caps 2 per day (patient $>$ \\
& $25 \mathrm{~kg})(\mathrm{n}=120) ;$ penicillin VK oral suspension $20 \mathrm{mg} / \mathrm{kg} /$ day 4 doses, daily max. $500 \mathrm{mg}$ or $250 \mathrm{mg}$ caps \\
& 4 per day (patient $>25 \mathrm{~kg})(\mathrm{n}=113)$ \\
& - Duration of treatment: 10 days \\
& - Duration of follow-up: 4 to 5 weeks \\
\hline Outcomes & - Clinical outcomes at 3 to 5 days post-treatment: cure (absence of presenting signs/symptoms); signif- \\
& icant improvement (persistence of signs/symptoms); failure (insignificant change in signs/symptoms); \\
& relapse (recurrence of one or more signs/symptoms) \\
& - Relapse at 5 to 6 weeks post-treatment \\
& - Adverse effects \\
& - Bacteriological outcomes \\
& - Funding: Eli Lilly Company \\
- Ethics approval: not mentioned & - No ITT reported for efficacy, but ITT for adverse events \\
\hline Notes &
\end{tabular}

\section{Risk of bias}

Bias Authors' judgement Support for judgement

Random sequence genera- Unclear risk Reported as "randomised (1:1), but no reporting of randomisation sequence. tion (selection bias)

\begin{tabular}{lll}
$\begin{array}{l}\text { Allocation concealment } \\
\text { (selection bias) }\end{array}$ & Unclear risk & Not described. \\
\hline $\begin{array}{l}\text { Blinding (performance } \\
\text { bias and detection bias) } \\
\text { All outcomes }\end{array}$ & Low risk & $\begin{array}{l}\text { "Placebo was administered twice daily to the loracarbef group to maintain } \\
\text { double blind conditions." }\end{array}$ \\
\hline $\begin{array}{l}\text { Incomplete outcome data } \\
\text { (attrition bias) } \\
\text { All outcomes }\end{array}$ & Low risk & $\begin{array}{l}\text { "unevaluable": } 16 \text { in loracarbef group and } 25 \text { in penicillin group (negative pre- } \\
\text { therapy culture, insufficient therapy, incomplete data, lost to follow-up, late } \\
\text { for visit, concomitant use of other antibiotic). } \\
\text { No ITT for clinical outcome. }\end{array}$ \\
\hline
\end{tabular}

$\begin{aligned} & \text { Selective reporting (re- } \quad \text { Unclear risk } \\ & \text { porting bias) }\end{aligned}$

Other bias High risk Funding: Eli Lilly Company

Henness 1982

Methods Study 1 :


Henness 1982 (Continued)

\author{
- RCT \\ - Double-blinded
}

Study 2:

- RCT, randomised

- Double-blinded

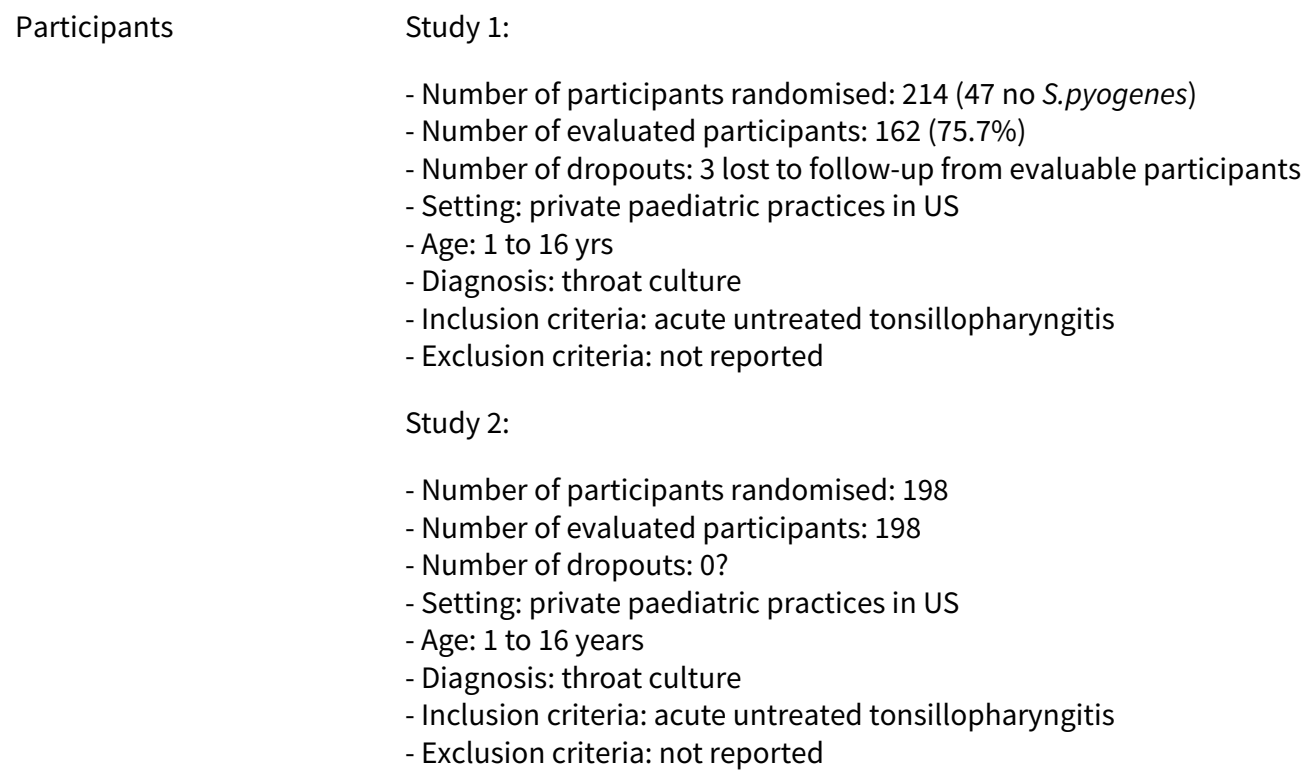

Study 2:

- Number of participants randomised: 198

- Number of evaluated participants: 198

- Number of dropouts: 0 ?

- Setting: private paediatric practices in US

- Age: 1 to 16 years

- Diagnosis: throat culture

- Inclusion criteria: acute untreated tonsillopharyngitis

- Exclusion criteria: not reported

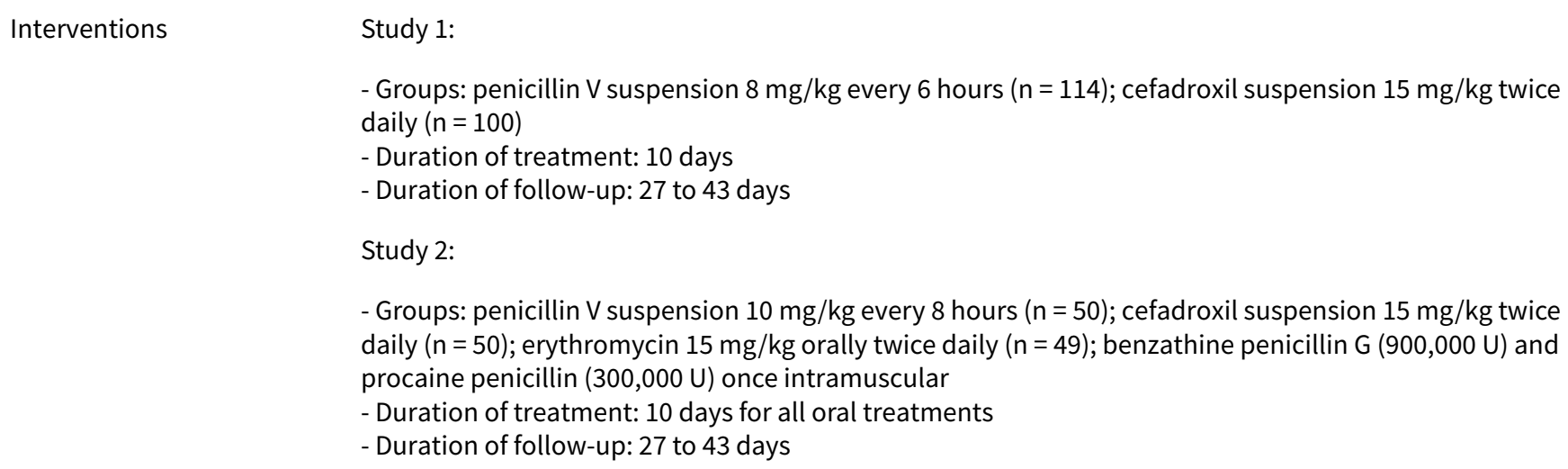

- Groups: penicillin V suspension $10 \mathrm{mg} / \mathrm{kg}$ every 8 hours $(\mathrm{n}=50)$; cefadroxil suspension $15 \mathrm{mg} / \mathrm{kg}$ twice daily $(n=50)$; erythromycin $15 \mathrm{mg} / \mathrm{kg}$ orally twice daily $(n=49)$; benzathine penicillin $\mathrm{G}(900,000 \mathrm{U})$ and procaine penicillin $(300,000 \mathrm{U})$ once intramuscular

- Duration of treatment: 10 days for all oral treatments

- Duration of follow-up: 27 to 43 days

- Clinical outcomes: cure (clinical improvement within first 24 hours of therapy and all follow-up cultures no S.pyogenes); failure (illness consistent with streptococcal infection and positive throat culture at 4 days post-therapy); carrier (asymptomatic with same type S. pyogenes in throat culture obtained between 5 to 33 days post-therapy)

- Bacteriological outcomes

- Complete blood counts

- Urinalysis

- Streptozyme titres

- Susceptibility studies

Study 2:

- Clinical outcomes: not reported

- Bacteriological outcomes

- Streptozyme titres 
Henness 1982 (Continued)

- Susceptibility

Study 1:
Notes
- Funding: not mentioned, author employee of Mead Johnson Pharmaceutical Division, Evansville, US
- Ethics approval: not mentioned
- First study in the publication
- No ITT reported
Study 2:
- Funding: not mentioned, author employee of Mead Johnson Pharmaceutical Division, Evansville, US
- Ethics approval: not mentioned
- Second study in the publication
- No ITT reported

\section{Risk of bias}

\begin{tabular}{lll}
\hline Bias & Authors' judgement & Support for judgement \\
\hline $\begin{array}{l}\text { Random sequence genera- } \\
\text { tion (selection bias) }\end{array}$ & Unclear risk & Study 1: \\
& Reported as "randomised", but no description of randomisation sequence. \\
& Study 2: \\
& Reported as "randomised", but no description of randomisation sequence. \\
\hline $\begin{array}{l}\text { Allocation concealment } \\
\text { (selection bias) }\end{array}$ & Unclear risk & Study 1: \\
& "...participants were assigned randomly..." \\
& Study 2: \\
& Not described.
\end{tabular}

Blinding (performance
bias and detection bias)

All outcomes
Unclear risk

Study 1:

Reported as "double blind", but no description of blinding.

Study 2:

Reported as "double blind", but no description of blinding.

\section{Study 1:}

52 participants discontinued (cefadroxil 35 and penicillin 17); reasons: negative culture (total 47; cefadroxil 31 and penicillin 16), lost to follow-up (total 3; cefadroxil 2 and penicillin 1), other (total 2; cefadroxil 2 and penicillin 0 ).

$24.3 \%$ post-randomisation dropout

No ITT analysis for clinical outcomes.

Study 2:

No dropouts described; according to reported numbers no participants dropped out.
Selective reporting (re-
Unclear risk
Study 1:
porting bias)
Only clinical (and bacteriological) cure reported, no specific symptoms; no ITT. Adverse events not reported. 
Henness 1982 (Continued)

Study 2:

No clinical outcomes reported.

Other bias High risk Author is employee of Mead Johnson Pharmaceutical Division, Evansville, US

\section{Jackson 1973}

\begin{tabular}{ll}
\hline Methods & - RCT \\
& - Double-blinded \\
\hline Participants & - Number of participants randomised: 314 (95 negative culture excluded from analysis) \\
& - Number of participants evaluated: 207 ( $70 \%)$ \\
& - Number of dropouts: 12 reported \\
& - Setting: not described \\
& - Age: not described \\
& - Diagnosis: throat culture \\
& - Inclusion criteria: child in weight range 11.4 to 45.4 kg, pharyngitis, positive culture or white blood \\
& count > 10,000 \\
& - Exclusion criteria: allergy to penicillin or lincomycin, received any antibiotics within previous 6 weeks \\
\hline Interventions & - Groups: clindamycin daily dose 150 to 450 mg ( $\mathrm{n}=156$ ); ampicillin daily dose 750 to 2000 mg ( $\mathrm{n}=158)$ \\
& - Duration of treatment: 10 days \\
& - Duration of follow-up: 26 to 28 days post-therapy \\
\hline Outcomes & - Adverse effects \\
& - Bacteriological outcomes \\
\hline Notes & - Funding: Upjohn Company \\
- Ethics approval: not mentioned \\
- ITT for adverse events
\end{tabular}

\section{Risk of bias}

\begin{tabular}{lll}
\hline Bias & Authors' judgement & Support for judgement \\
\hline $\begin{array}{l}\text { Random sequence genera- } \\
\text { tion (selection bias) }\end{array}$ & Unclear risk & Reported as "randomised", but no description of randomisation sequence. \\
\hline $\begin{array}{l}\text { Allocation concealment } \\
\text { (selection bias) }\end{array}$ & Low risk & $\begin{array}{l}\text { "Labels for each group were randomised, sealed in sequentially numbered en- } \\
\text { velopes,..." }\end{array}$ \\
\hline $\begin{array}{l}\text { Blinding (performance } \\
\text { bias and detection bias) } \\
\text { All outcomes }\end{array}$ & Low risk & See above. \\
\hline
\end{tabular}

\begin{tabular}{lll}
$\begin{array}{l}\text { Incomplete outcome data } \\
\text { (attrition bias) } \\
\text { All outcomes }\end{array}$ & High risk & $\begin{array}{l}95 \text { negative cultures excluded after randomisation; 12 positive cultures exclud- } \\
\text { ed due to failure to return first follow-up culture (C7 and A5). }\end{array}$ \\
\hline $\begin{array}{l}\text { Selective reporting (re- } \\
\text { porting bias) }\end{array}$ & Unclear risk & $\begin{array}{l}\text { Only clinical outcome for post-streptococcal sequelae. } \\
\text { ITT for adverse events. }\end{array}$ \\
\hline \begin{tabular}{l} 
Other bias \\
\hline
\end{tabular} & High risk & Funding: Upjohn Company \\
\hline
\end{tabular}


Levenstein 1991

\begin{tabular}{ll}
\hline Methods & - RCT \\
& - Double-blinded \\
& - Double-dummy \\
\hline Participants & - Number of participants enrolled: 243 ( $82 \mathrm{~S}$. pyogenes negative) \\
& - Number of participants evaluated in clinical outcome analysis: $125(51.4 \%)$ \\
& - Number of dropouts: 28 (12\%) \\
& - Setting: multicenter (Australia, New Zealand, Chile, South Africa) outpatient clinics \\
& - Age: 13 to 59 years \\
& - Diagnosis: rapid antigen test, throat culture \\
& - Inclusion criteria: body weight =/> 50 kg, ability to swallow capsules, sore throat with at least one oth- \\
& er sign of streptococcal pharyngitis (pharyngeal erythema/exudate, cervical lymph node tenderness, \\
& fever), positive rapid immunoassay for GABHS antigen \\
& - Exclusion criteria: hypersensitivity to erythromycin or penicillin, previous course clarithromycin or \\
& penicillin VK in this trial, renal impairment or history of glomerulonephritis, history of hepatic disease \\
& or liver enzyme elevation, history of cardiac valvular disease, rash symptomatic of scarlet fever, history \\
& of allergies and/or asthma
\end{tabular}

Interventions - Groups: clarithromycin, 250 mg capsules every 12 hours ( $n=128)$; penicillin VK, 250 mg caps every 6 hours $(n=115)$

- Duration of treatment: clarithromycin 8 to 10 days; penicillin VK 10 to 14 days

- Duration of follow-up: 15 to 56 days

\begin{tabular}{ll}
\hline Outcomes & - Clinical outcomes at 2 to 10 days post-treatment: cure (pre-treatment signs and symptoms resolved); \\
improvement (symptoms improved but not totally resolved); failure (symptoms not improved or wors- \\
ened); indeterminate (clinical response could not be assigned because of non-compliance or other rea- \\
sons) \\
- Relapse 15 to 56 days post-treatment \\
- Adverse effects \\
- Bacteriological outcomes \\
- Blood haematology and chemistry \\
- Urinalysis \\
- Funding: not reported \\
- Informed consent obtained \\
- Ethics approval: "the study was approved by local ethics committees" \\
- No ITT for efficacy, but ITT for adverse effects
\end{tabular}

\section{Risk of bias}

\begin{tabular}{lll}
\hline Bias & Authors' judgement & Support for judgement \\
\hline $\begin{array}{l}\text { Random sequence genera- } \\
\text { tion (selection bias) }\end{array}$ & Unclear risk & Reported as "randomised" but no description of randomisation sequence. \\
\hline $\begin{array}{l}\text { Allocation concealment } \\
\text { (selection bias) }\end{array}$ & Unclear risk & Not described. \\
\hline $\begin{array}{l}\text { Blinding (performance } \\
\text { bias and detection bias) }\end{array}$ & Low risk & Description of medication and placebo to ensure blinding. \\
All outcomes & \\
\hline $\begin{array}{l}\text { Incomplete outcome data } \\
\text { (attrition bias) }\end{array}$ & High risk & $\begin{array}{l}\text { Dropouts accounted for the bacteriological outcome analysis, but not for the } \\
\text { clinical outcome analysis (only } 125 \text { of 243 randomised participants included in } \\
\text { clinical outcome analysis). }\end{array}$ \\
& & \begin{tabular}{l}
$48.6 \%$ post-randomisation dropout \\
\hline
\end{tabular}
\end{tabular}




\begin{tabular}{|c|c|c|}
\hline $\begin{array}{l}\text { Selective reporting (re- } \\
\text { porting bias) }\end{array}$ & Unclear risk & $\begin{array}{l}\text { Safety analysis on all } 243 \text { randomised participants; clinical and bacteriological } \\
\text { outcome on only } 125 \text { participants. }\end{array}$ \\
\hline
\end{tabular}

Other bias Unclear risk $\quad$ Funding: not reported

\section{McCarty 1992a}

\begin{tabular}{ll}
\hline Methods & - RCT \\
& - Double-blinded \\
& - Double-dummy \\
\hline Participants & - Number of enrolled participants: 218 \\
& - Number of participants randomised: 218 (31 negative culture) \\
& - Number of participants evaluated: 171 ( $78.4 \%)$ \\
& - Number of dropouts: 47 (22\%) \\
& - Setting: 12 study centres in North America \\
& - Age: > 12 years \\
& - Diagnosis: rapid antigen test, throat culture \\
& - Inclusion criteria: clinical diagnosis of streptococcal pharyngitis or tonsillitis - inflammation of phar- \\
& ynx and tonsils with pain in the throat, with or without fever or exudate, rapid antigen test or throat cul- \\
& ture positive for GABHS \\
& - Exclusion criteria: pregnancy, lactation, history of renal impairment (serum creatinine levels $\geq 177$ \\
& $\mu$ mol/L, 2.0 mg/dL), physical or mental condition that might preclude evaluation of response, possi- \\
& ble future need for other systemic antibiotic during study, use of antibiotic therapy within 3 days of pre \\
& therapy evaluation, use of other investigational agents within previous 28 days, hypersensitivity to be- \\
& ta-lactam antibiotic
\end{tabular}

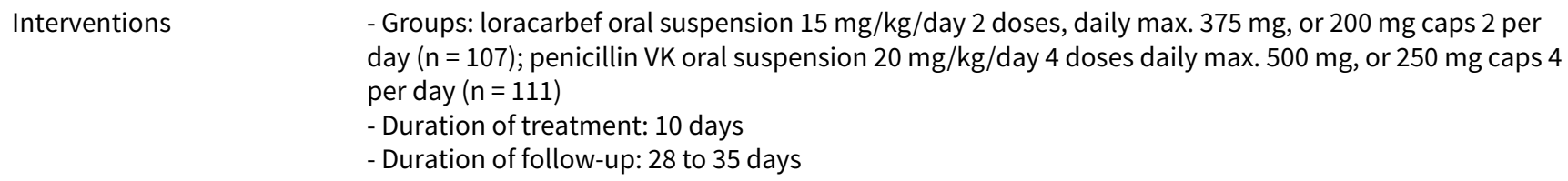

Outcomes - Clinical outcomes at 3 to 5 days post-treatment: cure (total alleviation of difficulty in swallowing, pharyngeal pain); improvement (substantial improvement in signs and symptoms); failure (signs and symptoms not substantially alleviated); relapse (initial improvement or alleviation of symptoms, but subsequent worsening or recurrence); unable to evaluate

- Relapse at 28 to 35 days post-treatment

- Adverse effects

- Bacteriological outcomes

\begin{tabular}{ll}
\hline Notes & - Funding: Eli Lilly and Company \\
& - Informed consent obtained \\
& - Ethics approval: not mentioned \\
& - No ITT reported for efficacy, but ITT reported for adverse events
\end{tabular}

\section{Risk of bias}

\section{Bias}

Authors' judgement Support for judgement

Random sequence genera- Unclear risk tion (selection bias)

Reported as "randomised"; no description of randomisation sequence. 
McCarty 1992a (Continued)

$\begin{aligned} & \text { Allocation concealment } \\ & \text { (selection bias) }\end{aligned}$ Unclear risk Not described.

\begin{tabular}{lll}
$\begin{array}{l}\text { Blinding (performance } \\
\text { bias and detection bias) } \\
\text { All outcomes }\end{array}$ & Low risk & $\begin{array}{l}\text { "In order to maintain blinding, placebo was administered twice daily to partici- } \\
\text { pants in the loracarbef group so that all participants received } 4 \text { doses daily." }\end{array}$ \\
\hline $\begin{array}{l}\text { Incomplete outcome data } \\
\text { (attrition bias) }\end{array}$ & High risk & $\begin{array}{l}\text { Dropouts: } 18 \text { in loracarbef group and } 29 \text { in penicillin group. Reasons for } \\
\text { dropout: negative culture (L12 and P19) insufficient therapy, incomplete data, } \\
\text { use of other antibiotic, noncompliance, lack of post-therapy culture). } \\
\end{array}$ \\
& $\begin{array}{l}21.6 \% \text { post-randomisation dropout } \\
\text { No ITT for clinical outcome. }\end{array}$
\end{tabular}

\begin{tabular}{lll}
\hline $\begin{array}{l}\text { Selective reporting (re- } \\
\text { porting bias) }\end{array}$ & Unclear risk & ITT for adverse events analysis. \\
\hline Other bias & High risk & Funding: Eli Lilly and Company \\
\hline
\end{tabular}

\section{Muller 1992}

\begin{tabular}{ll}
\hline Methods & - RCT \\
& - Double-blind \\
\hline
\end{tabular}

$\begin{array}{ll}\text { Participants } & \text { - Number of enrolled participants: } 344 \\ & \text { - Number of participants randomised: } 344 \\ & \text { - Number of participants evaluated: } 239(69.5 \%) \\ & \text { - Number of dropouts: } 105(31 \%) \\ & \text { - Setting: study centres in Europe and Israel } \\ & \text { - Age: } 3 \text { to } 80 \text { years (mean } 28.2) 10.8 \%<12 \text { years, } 2.0 \%>65 \mathrm{yrs} \\ & \text { - Diagnosis: rapid antigen test and confirmed by throat culture } \\ & \text { - Inclusion criteria: clinical diagnosis of streptococcal pharyngitis or tonsillitis and a positive rapid } \\ & \text { streptococcal antigen test. Selections were made on the basis of a demonstrated history of therapeutic } \\ & \text { compliance on the part of the patient and/or the patient's parent/guardian } \\ & \text { - Exclusion criteria: pregnant or nursing or history of renal impairment; any condition, including signif- } \\ & \text { icant underlying disease or concomitant infection, which in the opinion of the investigator could have } \\ & \text { precluded evaluation of response; anticipated need for systemic antibiotics; use of antibiotic < } 3 \text { days; } \\ & \text { or hypersensitivity to penicillins and/or cephalosporins }\end{array}$

Interventions

- Groups: 1 ) loracarbef $(n=169)$ suspension of $15 \mathrm{mg} / \mathrm{kg} /$ day in 2 divided doses up to a max daily dose $375 \mathrm{mg}$ or as a $200 \mathrm{mg}$ capsule twice daily, with placebo twice daily to maintain double-blind conditions. 2) penicillin $V(n=175$ suspension of $20 \mathrm{mg} / \mathrm{kg} /$ day in 4 divided doses up to a max daily dose of $500 \mathrm{mg}$ or as $250 \mathrm{mg}$ capsules) 4 times daily

- Duration of treatment: 10 days

- Duration of follow-up: 38 to 45 days

- Concomitant medication for treatment of underlying diseases or conditions was allowed with the exception of systemic antibiotics. During therapy paracetamol was used by $5.5 \%$ of the patients

Outcomes

\footnotetext{
- Clinical outcomes at days 4 to 6 : the patients' symptomatic responses and adherence to the treatment regimen; at days 13 to 15): physical examination to determine symptomatic response to therapy; at days 38 to 45: physical examination to evaluate possible recurrence of pharyngitis or tonsillitis. Throat cultures were required at every observation period

- Global symptomatic response based on symptom score (difficulty in swallowing, pharyngeal pain, pharyngeal redness, tonsillar inflammation, tonsillar swelling and temperature): cure, improvement (substantial), failure, relapse, or unable to evaluate

- Relapse: no definition given
} 
Muller 1992 (Continued)

- A patient was discontinued from the study if the pathogen isolated from initial culture was resistant to study antibiotic; if there was obvious symptomatic failure of the study antibiotic at any time during treatment; if there was a significant adverse event or a clinically significant alteration in a laboratory parameter; if a patient or parent/guardian wished to withdraw from the study; if the blinding was broken for safety reasons; or if the patient had an elevated pre-therapy serum creatinine - Adverse events: at least one adverse event was reported by loracarbef $=22(13.0 \%)$ and penicillin $\mathrm{V}$ $=19(10.9 \%)$ patients. Headache and nausea/vomiting were the only 2 events reported during therapy by more than $2 \%$ of the total population. Headache was reported by loracarbef $=5 / 169(3.0 \%)$ and by penicillin $V=4 / 175(2.3 \%)(P=0.696)$. Nausea or vomiting was reported by loracarbef $=2 / 169(1.2 \%)$ and by penicillin $\mathrm{V}=5 / 175(2.9 \%)(\mathrm{P}=0.272)$. Few patients (approximately $5 \%$ of the total population) reported adverse events during the 28 to 35 day post-therapy follow-up period

\begin{tabular}{ll}
\hline Notes & - Funding: grants from Lilly Research Centre Ltd. \\
& - Informed consent obtained \\
& - Ethics: "conducted according to ethical committee guidelines, including the Declaration of Helsinki \\
& (1983 Venice Amendment)" \\
& - No ITT analysis \\
\hline
\end{tabular}

\section{Risk of bias}

\begin{tabular}{|c|c|c|}
\hline Bias & Authors' judgement & Support for judgement \\
\hline $\begin{array}{l}\text { Random sequence genera- } \\
\text { tion (selection bias) }\end{array}$ & Unclear risk & Not described. \\
\hline $\begin{array}{l}\text { Allocation concealment } \\
\text { (selection bias) }\end{array}$ & Unclear risk & Not described. \\
\hline $\begin{array}{l}\text { Blinding (performance } \\
\text { bias and detection bias) } \\
\text { All outcomes }\end{array}$ & Low risk & "with placebo twice daily to maintain double-blind conditions." \\
\hline $\begin{array}{l}\text { Incomplete outcome data } \\
\text { (attrition bias) } \\
\text { All outcomes }\end{array}$ & High risk & $\begin{array}{l}54 \text { of the } 169 \text { ( } 31.9 \%) \text { loracarbef-treated and } 51 / 115(29.1 \%) \text { penicillin-treated } \\
\text { patients did not qualify for efficacy evaluation. The most common reasons for } \\
\text { disqualification in each therapy group were bacteriological (loracarbef }=37 \text {, } \\
\text { penicillin } V=3) ; 12 \text { patients in each group received either insufficient therapy, } \\
\text { had no follow-up data (lost to follow-up) or had incomplete data; loracarbef = } \\
3 \text { patients and penicillin } V=1 \text { were disqualified from the efficacy analysis due } \\
\text { to protocol violations; loracarbef = } 1 \text { patient was disqualified for efficacy eval- } \\
\text { uation because of the use of another antibiotic during the study period, and lo- } \\
\text { racarbef = } 1 \text { patient could not be evaluated because the post-therapy evalua- } \\
\text { tion was performed } 22 \text { days after discontinuing therapy. }\end{array}$ \\
\hline
\end{tabular}

\begin{tabular}{lll}
\hline $\begin{array}{l}\text { Selective reporting (re- } \\
\text { porting bias) }\end{array}$ & Unclear risk & All indicated outcomes are reported. \\
\hline Other bias & High risk & Funding: grants from Lilly Research Centre Ltd. \\
\hline
\end{tabular}

\section{NCT00643149}

\begin{tabular}{ll}
\hline Methods & - RCT \\
& - non-inferiority trial \\
& -15 May 2003 to 22 May 2004
\end{tabular}

Participants - Number of participants enrolled: target 626 (313 per arm) 
- Number of participants randomised: 693

- Number of evaluated (treated) participants: 673 (337 azithromycin and 336 amoxicillin)

- Number of participants discontinued: 125 (56 azithromycin and 69 amoxicillin)

- Age: Children 2 to 12 years

- Setting: Multicentre: 33 centres in North America (6 sites in Canada, 19 in US), Latin America (3 sites in Costa Rica, 1 in Guatamala), and India (4 sites); Paediatric outpatients

- Acute pharyngitis/tonsillitis based on "erythematous pharyngeal mucosa or thick exudate covering the pharynx and tonsillar area, and at least one of the following signs or symptoms: sore/scratchy throat; pain on swallowing; chills and/or fever; cervical adenopathy; scarlet fever rash on the face and skin folds, or red tongue with prominent papillae ("strawberry tongue")."

- Positive rapid antigen detection test or positive culture for GABHS

- GABHS pharyngitis/tonsillitis (tested for susceptibility to azithromycin and amoxicillin)

\begin{tabular}{ll} 
Interventions & - Azithromycin SR $60 \mathrm{mg} / \mathrm{kg}$ single dose $(\mathrm{n}=337)$; bacteriological per protocol population $(\mathrm{n}=245)$ \\
& - Amoxicillin $45 \mathrm{mg} / \mathrm{kg}$ twice daily for 10 days $(\mathrm{n}=336)$; bacteriological per protocol population $(\mathrm{n}=$ \\
\hline Outcomes & - Bacteriological cure (primary outcome) \\
& - Clinical success \\
& - Compliance \\
& - Adverse events \\
& - Time points of assessment: "Test of Cure" at 24 to 28 days after starting study drug; and long term fol- \\
& low-up on days 38 to 45
\end{tabular}

Notes
- Report provided by Pfizer
- Study supported and conducted by Pfizer
- Protocol No: A0661071
- Outcomes only reported for "Bacteriological Per Protocol Population", i.e. positive GABHS culture at
recruitment or within 48hrs of starting treatment, at least 8 days of study medication and assessment
at baseline

\section{Risk of bias}

\begin{tabular}{lll}
\hline Bias & Authors' judgement & Support for judgement \\
\hline $\begin{array}{l}\text { Random sequence genera- } \\
\text { tion (selection bias) }\end{array}$ & Unclear risk & Not described. \\
\hline $\begin{array}{l}\text { Allocation concealment } \\
\text { (selection bias) }\end{array}$ & Unclear risk & Not described. \\
\hline
\end{tabular}

\begin{tabular}{|c|c|c|}
\hline $\begin{array}{l}\text { Blinding (performance } \\
\text { bias and detection bias) } \\
\text { All outcomes }\end{array}$ & Low risk & Placebo matched to the active treatment. \\
\hline $\begin{array}{l}\text { Incomplete outcome data } \\
\text { (attrition bias) }\end{array}$ & High risk & $\begin{array}{l}\text { - In total } 693 \text { randomised; } 20 \text { were not treated due to insufficient drug supply } \\
\text { at study site (no more information given). }\end{array}$ \\
\hline
\end{tabular}


- Of 673 patients treated 125 patients discontinued (56 in azithromycin group and 69 in amoxicillin group); reasons for discontinuation provided (more dropout due to adverse events in azithromycin arm (4.7\% versus $0.9 \%)$ and more lack of efficacy in amoxicillin arm (8.3\% versus $3.3 \%)$ ).

Selective reporting (re- Unclear risk All outcomes reported.

Other bias High risk Study supported and conducted by Pfizer

Nemeth 1999

\begin{tabular}{ll}
\hline Methods & - RCT, randomised 1:1:1 \\
& - Double-blinded \\
& - Double-dummy \\
\hline Participants & - Number of participants enrolled: 919 \\
& - Number of positive throat cultures susceptible to study drugs: 725 \\
& - Number of participants evaluated: 644 \\
& - Number of dropouts: 275 (30\%) \\
& - Setting: 25 study centres in US and Canada \\
& - Age: $=/>13$ years \\
& - Diagnosis: rapid antigen test, throat culture \\
& - Inclusion criteria: throat culture positive for GABHS, at least 1 clinical sign or symptom of pharyngitis \\
& - Exclusion criteria: pregnancy, history of rheumatic fever or rheumatic heart disease, peritonsillar ab- \\
& scess or invasive disease, hypersensitivity to beta-lactam drugs, hepatic disease, hepatic enzyme levels \\
& or serum creatinine $>2$ times upper limit of normal, another systemic antibiotic within 3 days before \\
& first dose of study medication or for which < 5 half-lives had elapsed, enrolled in this study previously, \\
& received another investigational drug within 4 weeks before study admission
\end{tabular}

\begin{tabular}{ll}
\hline Interventions & - Groups: cefdinir $600 \mathrm{mg}$ four times a day $(\mathrm{n}=305)$; cefdinir $300 \mathrm{mg}$ twice a day $(\mathrm{n}=304) ;$ penicillin $\mathrm{V}$ \\
& $250 \mathrm{mg}$ four times a day $(\mathrm{n}=310)$ \\
& - Duration of treatment 10 days \\
& - Duration of follow-up 17 to 24 days post-therapy
\end{tabular}

- Clinical outcomes at day 4 to 9 after treatment: cure (all signs and symptoms absent or in satisfactory
remission and no further antibiotic therapy required); failure (absence of significant remission of signs
and symptoms or need for further antibiotic therapy); relapse (worsening of, or absence of significant
remission of, signs and symptoms 17 to 24 days post-therapy or need for further antibiotic therapy)
- Relapse at day 17 to 24 after treatment
- Adverse effects
- Bacteriological outcomes

Notes

- Funding: Parke-Davis Pharmaceutical Research, Ann Arbor, Michigan (first author is employee)

- Informed consent obtained

- Ethics approval: institutional review board approval obtained at each site

- No ITT for efficacy reported, but ITT for adverse events

\section{Risk of bias}

\section{Bias}

Authors' judgement Support for judgement

Random sequence genera- Unclear risk tion (selection bias)

Reported as "randomised", but no description of the randomisation sequence. 
Nemeth 1999 (Continued)

$\begin{aligned} & \text { Allocation concealment } \\ & \text { (selection bias) }\end{aligned}$
Unclear risk $\quad$ "Patients were randomly assigned in a 1:1:1 ratio.."

\begin{tabular}{|c|c|c|}
\hline $\begin{array}{l}\text { Blinding (performance } \\
\text { bias and detection bias) }\end{array}$ & Unclear risk & $\begin{array}{l}\text { "All participants took the same number of capsules daily. All regimens were } \\
\text { administered for } 10 \text { days." No description of the appearance of the capsules. }\end{array}$ \\
\hline
\end{tabular}

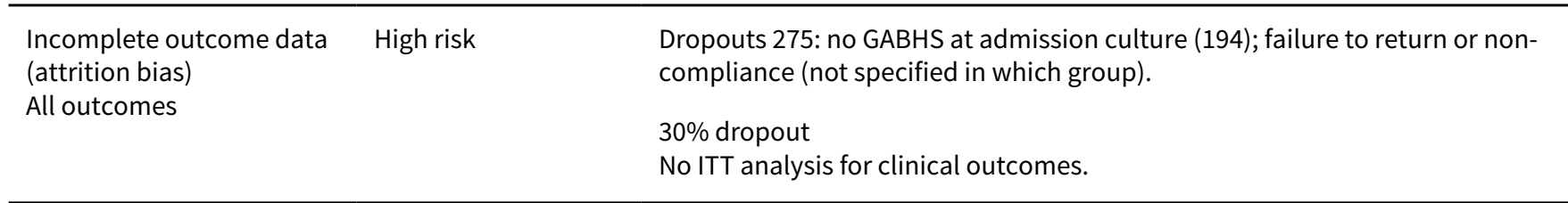

\begin{tabular}{lll}
\hline $\begin{array}{l}\text { Selective reporting (re- } \\
\text { porting bias) }\end{array}$ & Unclear risk & $\begin{array}{l}\text { Only clinical cure reported, no symptoms specified. } \\
\text { Adverse events analysed by ITT: } 21 \text { participants discontinued due to adverse } \\
\text { events (cefdinir = } 17 \text { and penicillin V = 4); difference between both groups not } \\
\text { significant. }\end{array}$ \\
\hline Other bias & High risk & $\begin{array}{l}\text { Funding: Parke-Davis Pharmaceutical Research, Ann Arbor, Michigan (first au- } \\
\text { thor is employee) }\end{array}$ \\
\hline
\end{tabular}

Norrby 2002

\begin{tabular}{ll}
\hline Methods & - RCT, randomised 1:1 \\
& - Double-blinded \\
& - Double-dummy \\
\hline
\end{tabular}

Participants
- Number of participants enrolled: 398
- Number of participants randomised: 396 (1 negative culture)
- Number of participants evaluated: 395
- Number of dropouts: 34 (9\%)
- Setting: 62 centres in 10 countries (Europe, New Zealand, S. Africa)
- Age: 15 to 74 years
- Diagnosis: rapid antigen test, throat culture
- Inclusion criteria: clinical signs and symptoms of acute pharyngitis/tonsillitis, including sore throat
and 1 or more others; presumed diagnosis of acute GABHS pharyngitis/tonsillitis, based on positive
rapid antigen detection test or throat culture within 24 hours prior to starting study medication
- Exclusion criteria: infection of deep tissues of upper respiratory tract or subpharyngeal respiratory
tract; head or neck cancer; history of rheumatic heart disease or valve disease, infectious mononucleo-
sis, rash; immunocompromised, impaired renal or hepatic function, history heart rhythm diseases, se-
vere hypokalaemia, any concomitant condition likely to preclude assessment of treatment response,
non-streptococcal or viral pharyngitis/tonsillitis, chronic streptococcal carrier, environmental risk of
reinfection, treatment with penicillin V, systemic or local antibiotic within 7 days prior to study entry;
pregnancy, lactation, hypersensitivity to study antibiotic, infection with a pathogen known to be resis-
tant to study drugs, concurrent treatment with other antibiotic or probenecid, or any medication that
may interact with study medication

Interventions $\quad$ - Groups: telithromycin $800 \mathrm{mg}$ oral once daily $(\mathrm{n}=198)$; penicillin V $500 \mathrm{mg}$ oral 3 times daily $(\mathrm{n}=197)$

- Duration of treatment: telithromycin 5 days; penicillin $V 10$ days

- Duration of follow-up: 38 to 45 days

Outcomes

\footnotetext{
- Clinical outcomes at day 16 to 20: cure (improvement, disappearance or return to preinfection state of all infection-related signs and symptoms, without additional antibiotic); failure (infection-related signs and symptoms unchanged or worsened, or clinical improvement but required additional antibiotic, developed new clinical findings consistent with active infection); indeterminate (missing post-treatment information, discontinued early for reasons unrelated to study drug)

- Relapse at day 38 to 45
} 
Norrby 2002 (Continued)

- Adverse effects

- Bacteriological outcomes

- Blood haematology

- Urinalysis

- Mean symptom score reported in second publication; no SD reported

\begin{tabular}{ll}
\hline Notes & - Funding: Aventis Pharma \\
& - Informed consent obtained \\
& - Ethics approval: "approved by and independent ethics committee in each country" \\
& - Modified ITT (1 patient with negative GABHS excluded) \\
& -2 publications of same study with different outcomes
\end{tabular}

\section{Risk of bias}

\begin{tabular}{|c|c|c|}
\hline Bias & Authors' judgement & Support for judgement \\
\hline $\begin{array}{l}\text { Random sequence genera- } \\
\text { tion (selection bias) }\end{array}$ & Unclear risk & Not described. \\
\hline $\begin{array}{l}\text { Allocation concealment } \\
\text { (selection bias) }\end{array}$ & Unclear risk & Reported as "randomised (1:1)"; Randomisation not described. \\
\hline $\begin{array}{l}\text { Blinding (performance } \\
\text { bias and detection bias) } \\
\text { All outcomes }\end{array}$ & Low risk & $\begin{array}{l}\text { "Blinding was maintained by masking the tablets in capsules and matching } \\
\text { placebo capsules where appropriate." }\end{array}$ \\
\hline $\begin{array}{l}\text { Incomplete outcome data } \\
\text { (attrition bias) } \\
\text { All outcomes }\end{array}$ & Low risk & $\begin{array}{l}\text { ITT for clinical outcomes excluded one randomised patient with negative cul- } \\
\text { ture; } 34 \text { participants discontinued, mainly due to withdrawal of consent or ad- } \\
\text { verse events; not clear how these reasons were distributed in the } 2 \text { groups. }\end{array}$ \\
\hline
\end{tabular}

Selective reporting (re- Unclear risk Cure was predefined clinical outcome; adverse events reported. porting bias)

Other bias High risk Funding: Aventis Pharma

\section{O'Doherty 1996}

\begin{tabular}{ll}
\hline Methods & - RCT \\
& - Double-blinded \\
& - Double-dummy \\
\hline Participants & - Number of participants enrolled: 489 (92 negative culture) (Azithromycin 20 mg = 160; Azithromycin 10 \\
& $\mathrm{mg}=166 ;$ Penicillin V = 163) \\
& - Number of participants evaluated: 358 \\
& - Number of dropouts: 131 excluded (Azithromycin $20 \mathrm{mg}=57$; Azithromycin $10 \mathrm{mg}=43 ;$ Penicillin V = \\
& $31)(27 \%)$ \\
& - Setting: 19 outpatient clinical centres (Europe) \\
& - Age: 2 to 13 years \\
& - Diagnosis: clinical examination, rapid antigen test \\
& - Inclusion criteria: clinical signs and symptoms suggestive of GABHS pharyngitis/tonsillitis, rapid anti- \\
& gen test positive for GABHS \\
- Exclusion criteria: within 72 hours prior to the study other antibiotic which could interfere with eval- \\
uation of therapy, hypersensitivity to macrolide or beta-lactam antibiotic, terminal illness or other se- \\
rious disease, any gastrointestinal condition that might affect drug absorption, other investigational \\
drug in the previous month or long-acting penicillin injections within the previous 6 weeks
\end{tabular}


O'Doherty 1996 (Continued)

Interventions
- Groups: azithromycin suspension single oral dose $10 \mathrm{mg} / \mathrm{kg}(\mathrm{n}=166)$; azithromycin suspension one single dose $20 \mathrm{mg} / \mathrm{kg}(\mathrm{n}=160$ ); penicillin $\mathrm{V}$ solution $50 \mathrm{mg} / \mathrm{ml}$ orally 4 times daily (total daily dose 500 to $1000 \mathrm{mg})(\mathrm{n}=163)$

- Duration of treatment: azithromycin 3 days; penicillin $\vee 10$ days

- Duration of follow-up: 28 to 30 days

\begin{tabular}{ll}
\hline Outcomes & - Clinical outcomes at day 12 to 14: cure; improvement; failure; relapse \\
& - Relapse at day 28 to 30 \\
& - Adverse effects \\
& - Bacteriological outcomes \\
& - Blood haematology and chemistry \\
& - Urinalysis \\
\hline Notes & - Funding: not reported \\
& - Informed consent obtained \\
& - Ethics approval: institutional review board approval obtained \\
& - Definition of outcomes not reported \\
& - No ITT for efficacy, but ITT for adverse effects \\
\hline
\end{tabular}

\section{Risk of bias}

\begin{tabular}{|c|c|c|}
\hline Bias & Authors' judgement & Support for judgement \\
\hline $\begin{array}{l}\text { Random sequence genera- } \\
\text { tion (selection bias) }\end{array}$ & Unclear risk & Reported as "randomised", but no description of randomisation sequence. \\
\hline $\begin{array}{l}\text { Allocation concealment } \\
\text { (selection bias) }\end{array}$ & Unclear risk & Not described. \\
\hline $\begin{array}{l}\text { Blinding (performance } \\
\text { bias and detection bias) } \\
\text { All outcomes }\end{array}$ & Low risk & $\begin{array}{l}\text { "Matched placebo suspensions or solutions were administered to maintain } \\
\text { blinding of the study." }\end{array}$ \\
\hline $\begin{array}{l}\text { Incomplete outcome data } \\
\text { (attrition bias) } \\
\text { All outcomes }\end{array}$ & High risk & $\begin{array}{l}\text { Dropout } 131 \text { participants: absence of pathogen (azithromycin } 20 \mathrm{mg}= \\
36 \text {; azithromycin } 10 \mathrm{mg}=30 \text {; penicillin = 26), deviation from protocol } \\
\text { (azithromycin } 20 \mathrm{mg}=10 \text {; azithromycin } 10 \mathrm{mg}=8 \text {; penicillin = 3), adverse event } \\
\text { (azithromycin } 20 \mathrm{mg}=11 \text {; azithromycin } 10 \mathrm{mg}=5 \text {; penicillin = 2) } \\
27 \% \text { post-randomisation dropout } \\
\text { No ITT analysis. }\end{array}$ \\
\hline $\begin{array}{l}\text { Selective reporting (re- } \\
\text { porting bias) }\end{array}$ & Unclear risk & $\begin{array}{l}\text { Only clinical (and bacteriological) cure reported, no specific symptoms in out- } \\
\text { come analysis } \\
\text { Adverse events reported with ITT analysis. }\end{array}$ \\
\hline Other bias & Unclear risk & Funding: not reported \\
\hline
\end{tabular}

\section{Randolph 1985}

\begin{tabular}{ll}
\hline Methods & - RCT \\
& - Double-blinded
\end{tabular}

\begin{tabular}{ll}
\hline Participants & - Number of eligible participants: 260 \\
& - Number of randomised participants: 194 \\
& - Number of participants evaluated: 194 \\
& - Number of dropouts: 0
\end{tabular}


Randolph 1985 (Continued)

- Setting: a private paediatric office

- Age: 2 to 20 years

- Diagnosis: throat culture

- Inclusion criteria: clinically suggestive GABHS pharyngitis

- Exclusion criteria: history of hypersensitivity to penicillin or cephalosporins, antibiotic within previous 72 hours

\begin{tabular}{ll}
\hline Interventions & - Groups: cefadroxil $250 \mathrm{mg}$ in 3 doses over next 18 to 24 hours $(\mathrm{n}=70)$; penicillin V 250 mg in 3 doses \\
& over next 18 to 24 hours $(\mathrm{n}=68) ;$ placebo $(\mathrm{n}=56)$ \\
& - Duration of treatment: 10 days \\
& - Duration of follow-up: 4 weeks (only results from examination 18 to 24 hours after initiation of treat- \\
& ment reported) \\
\hline Outcomes & - Clinical outcomes 24 hours after treatment start assessed by physician: improvement \\
& - Sore throat (numbers only reported in graph) \\
& - Fever (numbers only reported in graph) \\
& - Bacteriological outcomes \\
\hline Notes & - Funding: Mead Johnson and Company \\
- Ethics approval: not mentioned & - ITT analysis reported
\end{tabular}

\section{Risk of bias}

\begin{tabular}{lll}
\hline Bias & Authors' judgement & Support for judgement \\
\hline $\begin{array}{l}\text { Random sequence genera- } \\
\text { tion (selection bias) }\end{array}$ & Low risk & "All participants were then assigned by a table of random numbers..." \\
\hline $\begin{array}{l}\text { Allocation concealment } \\
\text { (selection bias) }\end{array}$ & Low risk & $\begin{array}{l}\text { "Randomization of treatment regimens was performed by a study nurse so } \\
\text { that the evaluating physician, parents and participants were unaware of which } \\
\text { agent was dispensed." }\end{array}$ \\
\hline $\begin{array}{l}\text { Blinding (performance } \\
\text { bias and detection bias) } \\
\begin{array}{l}\text { All outcomes } \\
\text { L }\end{array}\end{array}$ & Low risk & See above. \\
\hline
\end{tabular}

\begin{tabular}{lll}
\hline $\begin{array}{l}\text { Incomplete outcome data } \\
\text { (attrition bias) } \\
\text { All outcomes }\end{array}$ & Low risk & No dropouts (all randomised participants evaluated). \\
\hline $\begin{array}{l}\text { Selective reporting (re- } \\
\text { porting bias) }\end{array}$ & Unclear risk & $\begin{array}{l}\text { Specific signs and symptoms reported. } \\
\text { No reporting of adverse events. }\end{array}$ \\
\hline Other bias & High risk & Funding: Mead Johnson and Company \\
\hline
\end{tabular}

Reed 1991

\begin{tabular}{ll}
\hline Methods & - RCT \\
& - Double-blinded \\
\hline Participants & - Number of participants enrolled and randomised: 116 \\
& - Number of evaluated participants: 93 \\
& - Number of dropouts: $23(20 \%)$ \\
& - Setting: 4 primary care offices in US \\
& - Age: > 1 month \\
& - Diagnosis: rapid test, throat culture \\
\hline
\end{tabular}


Reed 1991 (Continued)

- Inclusion criteria: sore throat or poor eating, rapid test positive for GABHS

- Exclusion criteria: allergy to penicillin or cephalosporins, pregnancy, history of renal or hepatic impairment, significant underlying disease or concomitant infection that could preclude evaluation of response to treatment, antibiotic in the previous 3 days

\begin{tabular}{ll}
\hline Interventions & - Groups: cefaclor $20 \mathrm{mg} / \mathrm{kg} /$ day in 3 doses $(\mathrm{n}=60) ;$ penicillin VK $20 \mathrm{mg} / \mathrm{kg} / \mathrm{day}$ in 3 doses $(\mathrm{n}=56)$ \\
& - Duration of treatment: 10 days \\
& - Duration of follow-up: 28 to 30 days post-therapy \\
\hline Outcomes & - Clinical outcomes (not defined; according to clinician's impression at 2 days after treatment comple- \\
& tion): cure, improvement, relapse, failure \\
& - Relapse at day 28 to 30 \\
& - Adverse effects \\
& - Bacteriological outcomes \\
& - Beta-lactamase enzyme production \\
& - Funding: Eli Lily \& Company, Indianapolis, Indiana US \\
- Informed consent obtained \\
- Ethics approval not mentioned \\
- No ITT reported
\end{tabular}

\section{Risk of bias}

\begin{tabular}{|c|c|c|}
\hline Bias & Authors' judgement & Support for judgement \\
\hline $\begin{array}{l}\text { Random sequence genera- } \\
\text { tion (selection bias) }\end{array}$ & Unclear risk & Not described. \\
\hline $\begin{array}{l}\text { Allocation concealment } \\
\text { (selection bias) }\end{array}$ & Low risk & $\begin{array}{l}\text { "The patient was given a prescription that used a code number to identify the } \\
\text { medication to be used." }\end{array}$ \\
\hline $\begin{array}{l}\text { Blinding (performance } \\
\text { bias and detection bias) } \\
\text { All outcomes }\end{array}$ & Low risk & $\begin{array}{l}\text { "The identity of the antibiotic was unknown to the physician and to the pa- } \\
\text { tient, and was randomised by a coding sheet that was available only to the } \\
\text { pharmacists dispensing the study medication." }\end{array}$ \\
\hline $\begin{array}{l}\text { Incomplete outcome data } \\
\text { (attrition bias) } \\
\text { All outcomes }\end{array}$ & High risk & $\begin{array}{l}\text { Dropouts 23: no GABHS on culture (cefaclor } 6 \text { and penicillin 2), insufficient } \\
\text { therapy (cefaclor } 0 \text { and penicillin } 1 \text { ), no follow-up culture (cefaclor } 3 \text { and peni- } \\
\text { cillin } 0 \text { ), other antibiotic (cefaclor } 1 \text { and penicillin 2), could not be evaluated } \\
\text { according to investigator (cefaclor } 3 \text { and penicillin 5). } \\
20 \% \text { post-randomisation dropout } \\
\text { No ITT analysis. }\end{array}$ \\
\hline
\end{tabular}

\begin{tabular}{|c|c|c|}
\hline $\begin{array}{l}\text { Selective reporting (re- } \\
\text { porting bias) }\end{array}$ & Unclear risk & $\begin{array}{l}\text { Only clinical (and bacteriological) outcome reported, no specific symptom } \\
\text { outcomes reported } \\
\text { Adverse events reported; no ITT analysis. }\end{array}$ \\
\hline
\end{tabular}

Other bias High risk Funding: Eli Lily \& Company, Indianapolis, Indiana US

\section{Stein 1991}

\begin{tabular}{ll}
\hline Methods & - RCT \\
& - Double-blinded \\
& - Double-dummy \\
\hline Participants & - Number of participants enrolled and randomised: 128 (clarithromycin 65 and penicillin 63$)$ \\
& - Number of participants with S. pyogenes: 109
\end{tabular}


Stein 1991 (Continued)

- Number of participants evaluated: 95 (clarithromycin 47 and penicillin 48)

- Number of dropouts: 33 (26\%)

- Setting: multicentre (not specified)

- Age: 12 to 58 years

- Diagnosis: clinical examination, rapid immunoassay test

- Inclusion criteria: signs and symptoms of streptococcal throat infection, rapid immunoassay test pos-

itive for GABHS antigen

- Exclusion criteria: age < 12 years, pregnancy, lactation, hypersensitivity to erythromycin or penicillin, receiving antibiotics, impaired renal or liver function

\begin{tabular}{ll}
\hline Interventions & - Groups: clarithromycin 250 mg capsule every 12 hours ( $\mathrm{n}=65)$; penicillin V 250 mg capsule every 6 \\
& hours $(\mathrm{n}=63)$ \\
& - Duration of treatment: 10 days \\
& - Duration of follow-up: 29 to 35 days \\
\hline Outcomes & - Clinical outcomes at day 5 to 7 and at day 14 to $16:$ cure (complete resolution of signs and symptoms); \\
& improved (considerable resolution of presenting signs and symptoms); failure (no improvement) \\
& - Relapse at day 29 to 35 \\
& - Adverse effects \\
& - Bacteriological outcomes \\
& - Blood haematology and chemistry \\
& - Urinalysis \\
& - Serology (antistreptolysin-O titres, anti-DNase B titres)
\end{tabular}

\begin{tabular}{ll}
\hline Notes & - Funding: not reported \\
& - Ethics approval: not mentioned \\
& - No ITT for efficacy, but ITT for adverse effects \\
\hline
\end{tabular}

\section{Risk of bias}

\begin{tabular}{|c|c|c|}
\hline Bias & Authors' judgement & Support for judgement \\
\hline $\begin{array}{l}\text { Random sequence genera- } \\
\text { tion (selection bias) }\end{array}$ & Unclear risk & "Random number code" was used, but unclear how it was generated. \\
\hline $\begin{array}{l}\text { Allocation concealment } \\
\text { (selection bias) }\end{array}$ & Unclear risk & Not described. \\
\hline $\begin{array}{l}\text { Blinding (performance } \\
\text { bias and detection bias) } \\
\text { All outcomes }\end{array}$ & Low risk & $\begin{array}{l}\text { "In order to maintain blinding of the study placebo capsules were alternated } \\
\text { with clarithromycin capsules every six hours." }\end{array}$ \\
\hline $\begin{array}{l}\text { Incomplete outcome data } \\
\text { (attrition bias) } \\
\text { All outcomes }\end{array}$ & High risk & Dropouts 33 (26\%); no description of reasons; no ITT for clinical outcomes. \\
\hline $\begin{array}{l}\text { Selective reporting (re- } \\
\text { porting bias) }\end{array}$ & Unclear risk & $\begin{array}{l}\text { Clinical (and bacteriological) cure rate reported, no specific symptoms. } \\
\text { Adverse events reported with ITT analysis. }\end{array}$ \\
\hline Other bias & Unclear risk & Funding: not reported \\
\hline
\end{tabular}

Trickett 1973

$\begin{array}{ll}\text { Methods } & \text { - RCT } \\ & \text { - Double-blinded } \\ & \text { - Double-dummy }\end{array}$


Trickett 1973 (Continued)

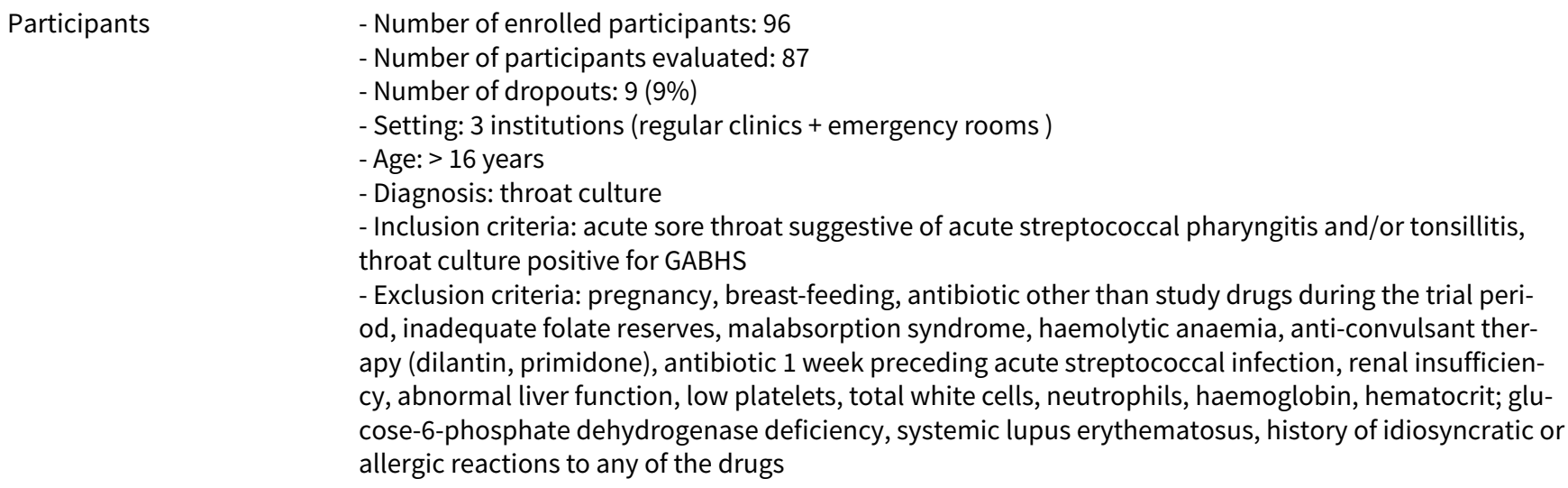

\begin{tabular}{ll}
\hline Outcomes & - No clinical outcomes reported \\
& - Adverse effects \\
& - Bacteriological outcomes \\
& - Urinalysis \\
& - Creatinine \\
& - Liver function: Serum Glutamic Oxaloacetic Transaminase (SGOT) or Aspartate transaminase (AST) \\
\hline Notes & - Funding: medication supplied by Hoffmann-LaRoche Inc. \\
& - Ethics approval: not mentioned
\end{tabular}

\section{Risk of bias}

\begin{tabular}{lll}
\hline Bias & Authors' judgement & Support for judgement \\
\hline $\begin{array}{l}\text { Random sequence genera- } \\
\text { tion (selection bias) }\end{array}$ & Unclear risk & $\begin{array}{l}\text { Reported as "randomised" but no description of randomisation sequence; } \\
\text { "both groups were evenly matched as to age, sex, physical condition, and con- } \\
\text { current diagnoses." }\end{array}$ \\
\hline $\begin{array}{l}\text { Allocation concealment } \\
\text { (selection bias) }\end{array}$ & Unclear risk & Not described. \\
\hline $\begin{array}{l}\text { Blinding (performance } \\
\text { bias and detection bias) } \\
\text { All outcomes }\end{array}$ & Low risk & $\begin{array}{l}\text { "all test medications were supplied in individually coded bottles of identical } \\
\text { appearance and were administered according to the randomised double blind } \\
\text { code." }\end{array}$ \\
\hline $\begin{array}{l}\text { Incomplete outcome data } \\
\text { (attrition bias) } \\
\text { All outcomes }\end{array}$ & Low risk & $\begin{array}{l}\text { 9 dropouts: lost to follow-up, failed to take medication or negative on strep A } \\
\text { tests (not specified per group). } \\
\text { No ITT analysis. }\end{array}$ \\
\hline $\begin{array}{l}\text { Selective reporting (re- } \\
\text { porting bias) }\end{array}$ & Unclear risk & $\begin{array}{l}\text { Cure rates reported, not individual symptoms. } \\
\text { Adverse events mentioned, but not tested. }\end{array}$ \\
\hline \begin{tabular}{l} 
Other bias \\
\hline
\end{tabular} & Unclear risk & \begin{tabular}{l} 
Funding: medication supplied by Hoffmann-LaRoche Inc. \\
\hline
\end{tabular}
\end{tabular}


Watkins 1997

\begin{tabular}{|c|c|}
\hline Methods & $\begin{array}{l}\text { - RCT } \\
\text { - Double-blinded } \\
\text { - Double-dummy }\end{array}$ \\
\hline Participants & $\begin{array}{l}\text { - Number of participants randomised: } 345 \text { (dirithromycin } 170 \text { and penicillin 175) } \\
\text { - Number of participants evaluated: } 257 \text { (dirithromycin } 121 \text { and penicillin 136) } \\
\text { - Number of dropouts: } 66 \text { in each group (38\%) } \\
\text { - Setting: } 15 \text { clinical centres in North America } \\
\text { - Age: > } 12 \text { years } \\
\text { - Diagnosis: rapid antigen test, throat culture } \\
\text { - Inclusion criteria: weight > } 81 \text { lb, positive throat culture, informed consent, ability to return for fol- } \\
\text { low-up, negative pregnancy test and use of a reliable method of contraception during therapy and for } \\
30 \text { days thereafter } \\
\text { - Exclusion criteria: any condition precluding evaluation of response to treatment, systemic antibiot- } \\
\text { ic other than the study antibiotic; hypersensitivity to macrolides, penicillins, cephalosporins, pregnan- } \\
\text { cy, breast-feeding, systemic antibiotic in } 7 \text { days before study; participation in a previous dirithromycin } \\
\text { study or any study involving and investigational drug in the } 30 \text { days prior to this study }\end{array}$ \\
\hline Interventions & $\begin{array}{l}\text { - Groups: dirithromycin, } 500 \text { mg once daily }(n=170) \text {; penicillin VK } 250 \text { mg } 4 \text { times daily }(n=175) \\
\text { - Duration of treatment: } 10 \text { days } \\
\text { - Duration of follow-up: } 3 \text { to } 5 \text { weeks post-treatment }\end{array}$ \\
\hline Outcomes & $\begin{array}{l}\text { - Clinical outcomes } 3 \text { to } 5 \text { days post-treatment: cure (elimination of signs and symptoms); improvement } \\
\text { (significant but incomplete resolution of signs and symptoms); relapse (worsening of signs and symp- } \\
\text { toms after initial improvement); failure (no improvement in signs and symptoms during treatment) } \\
\text { - Clinical relapse at } 3 \text { to } 5 \text { weeks post-treatment not reported } \\
\text { - Adverse effects } \\
\text { - Bacteriological outcomes }\end{array}$ \\
\hline Notes & $\begin{array}{l}\text { - Funding: Eli Lilly and Company ( } 2 \text { authors are employees) } \\
\text { - Ethics approval: not mentioned } \\
\text { - No ITT for efficacy, but ITT for adverse effects }\end{array}$ \\
\hline
\end{tabular}

\section{Risk of bias}

\begin{tabular}{|c|c|c|}
\hline Bias & Authors' judgement & Support for judgement \\
\hline $\begin{array}{l}\text { Random sequence genera- } \\
\text { tion (selection bias) }\end{array}$ & Low risk & Sequence generated by computer programme. \\
\hline $\begin{array}{l}\text { Allocation concealment } \\
\text { (selection bias) }\end{array}$ & Low risk & $\begin{array}{l}\text { "The randomisation list was not provided to the investigators until the study } \\
\text { was complete.." }\end{array}$ \\
\hline $\begin{array}{l}\text { Blinding (performance } \\
\text { bias and detection bias) } \\
\text { All outcomes }\end{array}$ & Low risk & $\begin{array}{l}\text { "Double dummy design" "This was accomplished by giving two bottles to each } \\
\text { patient, one containing } 20 \text { tablets (dirithromycin or placebo) and one contain- } \\
\text { ing } 40 \text { capsules (penicillin or placebo)." }\end{array}$ \\
\hline $\begin{array}{l}\text { Incomplete outcome data } \\
\text { (attrition bias) } \\
\text { All outcomes }\end{array}$ & High risk & $\begin{array}{l}\text { Description of dropouts in each group: lack of efficacy (dirithromycin 20; } \\
\text { penicillin 26), lost to follow-up (dirithromycin 4; penicillin 1), patient's deci- } \\
\text { sion (dirithromycin 3; penicillin 0), entry criteria exclusion (dirithromycin 25; } \\
\text { penicillin 22), protocol violation (dirithromycin 8; penicillin 8), adverse event } \\
\text { (dirithromycin 6; penicillin 9) } \\
38 \% \text { post-randomisation dropout } \\
\text { No ITT analysis. }\end{array}$ \\
\hline
\end{tabular}

\begin{tabular}{|c|c|c|}
\hline $\begin{array}{l}\text { Selective reporting (re- } \\
\text { porting bias) }\end{array}$ & Unclear risk & $\begin{array}{l}\text { Only clinical cure reported, no specific symptoms. } \\
\text { Adverse events reported with ITT. }\end{array}$ \\
\hline
\end{tabular}


Watkins 1997 (Continued)
Other bias
High risk
Funding: Eli Lilly and Company (2 authors are employees)

GABHS: group A beta-haemolytic streptococcus

ITT: intention-to-treat analysis

kg: kilogram weight

lb: pound weight

$\mathrm{RCT}$ : randomised controlled trial

SD: standard deviation

Characteristics of excluded studies [ordered by study ID]

\begin{tabular}{|c|c|}
\hline Study & Reason for exclusion \\
\hline Adam 1994 & Not double-blinded \\
\hline Adam 1995 & Not double-blinded \\
\hline Adam 1996 & Not double-blinded \\
\hline Adam 2000a & Not double-blinded \\
\hline Adam 2000b & Not double-blinded \\
\hline Adam 2001 & Not double-blinded \\
\hline Aujard 1995 & Not double-blinded \\
\hline Bottaro 2012 & Open-label study \\
\hline Breese 1974 & Did not compare 2 different classes of antibiotics \\
\hline Cohen 2002 & Not double-blinded \\
\hline Cruz 2011 & Meta-analysis \\
\hline Davies 1995 & Not only acute GABHS tonsillopharyngitis \\
\hline De Meyere 1992 & Not RCT \\
\hline Del Mar 2008 & Commentary of RCT \\
\hline Denny 1953 & Not double-blinded \\
\hline Disney 1979 & Did not compare 2 different classes of antibiotics \\
\hline Dykhuizen 1996 & Not double-blinded \\
\hline Esposito 2002 & Not double-blinded \\
\hline Feder 1999 & Not double-blinded \\
\hline Gerber 1986 & Not double-blinded \\
\hline Gerber 1999a & Did not report any clinical outcomes \\
\hline
\end{tabular}




\begin{tabular}{|c|c|}
\hline Study & Reason for exclusion \\
\hline Gooch 1993 & Not double-blinded \\
\hline Granizio 2008 & Pooled analysis; not original studies \\
\hline Hamill 1993 & Not double-blinded \\
\hline Haverkorn 1971 & $\begin{array}{l}\text { Not RCT } \\
\text { Did not compare } 2 \text { different classes of antibiotics }\end{array}$ \\
\hline Holm 1991 & Not double-blinded \\
\hline Howe 1997 & Not double-blinded \\
\hline Kuroki 2013 & Open-label study \\
\hline Lennon 2008 & Not double-blinded (investigator blinded only) \\
\hline Matsen 1974 & Did not compare 2 different classes of antibiotics \\
\hline McCarty $1992 b$ & Not double-blinded \\
\hline McCarty 1994 & Not double-blinded \\
\hline Mclsaac 2004 & Did not compare 2 different classes of antibiotics \\
\hline Milatovic 1991 & Not double-blinded \\
\hline Milatovic 1993 & Not double-blinded \\
\hline NCT00393744 & Not double-blinded \\
\hline Pacifico 1996 & Not double-blinded \\
\hline Perkins 1969 & Not double-blinded \\
\hline Pichichero 2000 & Not double-blinded \\
\hline Pichichero 2008 & Not double-blinded (investigator blinded only) \\
\hline Portier 1990 & Not double-blinded \\
\hline Portier 1994 & Not double-blinded \\
\hline Rimoin 2011 & Did not compare 2 different classes of antibiotics \\
\hline Roos 1997 & Recurrent sore throat \\
\hline Sakata 2008 & Not double-blinded \\
\hline Shapera 1973 & Not double-blinded \\
\hline Shvartzman 1993 & Not double-blinded \\
\hline Siegel 1961 & Did not compare 2 different classes of antibiotics \\
\hline
\end{tabular}




\begin{tabular}{ll}
\hline Study & Reason for exclusion \\
\hline Standaert 1997 & Not only acute GABHS tonsillopharyngitis \\
\hline Stelter 2014 & Review of results of tonsillectomy \\
\hline Stillerman 1970 & No information on blinding and no data on clinical outcomes \\
\hline Stillerman 1986 & Not double-blinded \\
\hline Tack 1997 & Not double-blinded \\
\hline Tack 1998 & Not double-blinded \\
\hline Uysal 2000 & Not double-blinded \\
\hline Van Brusselen 2014 & Review of tonsillitis guidelines \\
\hline Zwart 2000 & Did not compare 2 different classes of antibiotics \\
\hline
\end{tabular}

GABHS: group A beta-haemolytic streptococci

$\mathrm{RCT}$ : randomised controlled trial

Characteristics of studies awaiting assessment [ordered by study ID]

Eslami 2014

Methods $\quad$ "To compare clinical and bacteriologic responses to intramuscular benzathine penicillin G (BPG) and single dose of amoxicillin in Group A streptococcal (GAS) pharyngitis."

Participants

" 571 children from 6 to 15 years old age, with pharyngitis, who were admitted to 45 elementary and guidance schools from 7 regions of Education Organization in North-East of Iran, Mashhad. They were screened for enrolment and if he/she presented pharyngitis with clinical criteria of sore throat, erythema, exudate and tender or enlarged anterior cervical lymph nodes. Exclusion criteria included reports of antibiotic use, negative throat culture for GAS and history of allergy to the drugs."

Interventions $\quad$ "...intramuscular benzathine penicillin G (BPG) and single dose of amoxicillin in Group A strepto-
coccal (GAS) pharyngitis..."

"Results: In the amoxicillin group, treatment failure was more than the penicillin group ( $18.9 \%$ vs. $6.4 \%$, respectively) but the difference was not statistically significant $(P<0.05)$. Both drugs were significantly effective in reducing pharyngitis manifestations but penicillin was significantly more effective in reducing exudate than amoxicillin."

\begin{tabular}{ll}
\hline Outcomes & Clinical and bacteriologic responses. \\
\hline Notes & No information on study design provided in the available abstract. Authors contacted for details. \\
\hline
\end{tabular}

$\mathrm{RCT}$ : randomised controlled trial

DATA AND ANALYSES 
Comparison 1. Cephalosporin versus penicillin

\begin{tabular}{|c|c|c|c|c|}
\hline Outcome or subgroup title & $\begin{array}{l}\text { No. of } \\
\text { studies }\end{array}$ & $\begin{array}{l}\text { No. of } \\
\text { partici- } \\
\text { pants }\end{array}$ & Statistical method & Effect size \\
\hline $\begin{array}{l}1 \text { Resolution of symptoms post-treatment } \\
\text { (ITT analysis) }\end{array}$ & 5 & 2018 & $\begin{array}{l}\text { Odds Ratio (M-H, Random, } \\
95 \% \mathrm{Cl})\end{array}$ & $0.79[0.55,1.12]$ \\
\hline 1.1 Adults & 2 & 1163 & $\begin{array}{l}\text { Odds Ratio (M-H, Random, } \\
95 \% \mathrm{Cl})\end{array}$ & $0.78[0.60,1.01]$ \\
\hline 1.2 Children & 3 & 855 & $\begin{array}{l}\text { Odds Ratio (M-H, Random, } \\
95 \% \mathrm{Cl})\end{array}$ & $0.83[0.40,1.73]$ \\
\hline $\begin{array}{l}2 \text { Resolution of symptoms post-treatment } \\
\text { (evaluable participants) }\end{array}$ & 5 & 1660 & $\begin{array}{l}\text { Odds Ratio (M-H, Random, } \\
95 \% \mathrm{Cl})\end{array}$ & $0.51[0.27,0.97]$ \\
\hline 2.1 Adults & 2 & 880 & $\begin{array}{l}\text { Odds Ratio (M-H, Random, } \\
95 \% \mathrm{Cl})\end{array}$ & $0.56[0.24,1.32]$ \\
\hline 2.2 Children & 3 & 780 & $\begin{array}{l}\text { Odds Ratio (M-H, Random, } \\
95 \% \mathrm{Cl})\end{array}$ & $0.46[0.14,1.52]$ \\
\hline $\begin{array}{l}3 \text { Resolution of symptoms within } 24 \text { hours of } \\
\text { treatment (ITT analysis) }\end{array}$ & 1 & 138 & $\begin{array}{l}\text { Odds Ratio (M-H, Random, } \\
95 \% \mathrm{Cl})\end{array}$ & $0.97[0.34,2.74]$ \\
\hline 3.1 Children & 1 & 138 & $\begin{array}{l}\text { Odds Ratio (M-H, Random, } \\
95 \% \mathrm{Cl})\end{array}$ & $0.97[0.34,2.74]$ \\
\hline 4 Sore throat (ITT analysis) & 1 & 138 & $\begin{array}{l}\text { Odds Ratio (M-H, Random, } \\
95 \% \mathrm{Cl})\end{array}$ & $0.97[0.23,4.04]$ \\
\hline 5 Fever (ITT analysis) & 1 & 138 & $\begin{array}{l}\text { Odds Ratio (M-H, Random, } \\
95 \% \mathrm{Cl})\end{array}$ & $0.97[0.19,4.98]$ \\
\hline $\begin{array}{l}6 \text { Incidence of relapse (evaluable partici- } \\
\text { pants) }\end{array}$ & 4 & 1386 & $\begin{array}{l}\text { Odds Ratio (M-H, Random, } \\
95 \% \mathrm{Cl})\end{array}$ & $0.55[0.30,0.99]$ \\
\hline 6.1 Adults & 2 & 770 & $\begin{array}{l}\text { Odds Ratio (M-H, Random, } \\
95 \% \mathrm{Cl})\end{array}$ & $0.42[0.20,0.88]$ \\
\hline 6.2 Children & 2 & 616 & $\begin{array}{l}\text { Odds Ratio (M-H, Random, } \\
95 \% \mathrm{Cl})\end{array}$ & $0.89[0.33,2.45]$ \\
\hline 7 Complications (ITT analysis) & 1 & 244 & $\begin{array}{l}\text { Odds Ratio (M-H, Random, } \\
95 \% \mathrm{Cl})\end{array}$ & $0.0[0.0,0.0]$ \\
\hline 8 Adverse events (ITT analysis) & 3 & 1279 & $\begin{array}{l}\text { Odds Ratio (M-H, Random, } \\
95 \% \mathrm{Cl})\end{array}$ & $0.94[0.27,3.25]$ \\
\hline $\begin{array}{l}9 \text { Resolution of symptoms ITT (subgroup } \\
\text { sponsored versus no sponsor reported) }\end{array}$ & 5 & 2018 & $\begin{array}{l}\text { Odds Ratio (M-H, Random, } \\
95 \% \mathrm{Cl})\end{array}$ & $0.79[0.55,1.12]$ \\
\hline 9.1 Sponsor not reported & 2 & 769 & $\begin{array}{l}\text { Odds Ratio (M-H, Random, } \\
95 \% \mathrm{Cl})\end{array}$ & $0.47[0.27,0.81]$ \\
\hline 9.2 Sponsored studies & 3 & 1249 & $\begin{array}{l}\text { Odds Ratio (M-H, Random, } \\
95 \% \mathrm{Cl})\end{array}$ & $0.90[0.70,1.16]$ \\
\hline
\end{tabular}


Analysis 1.1. Comparison 1 Cephalosporin versus penicillin, Outcome 1 Resolution of symptoms post-treatment (ITT analysis).

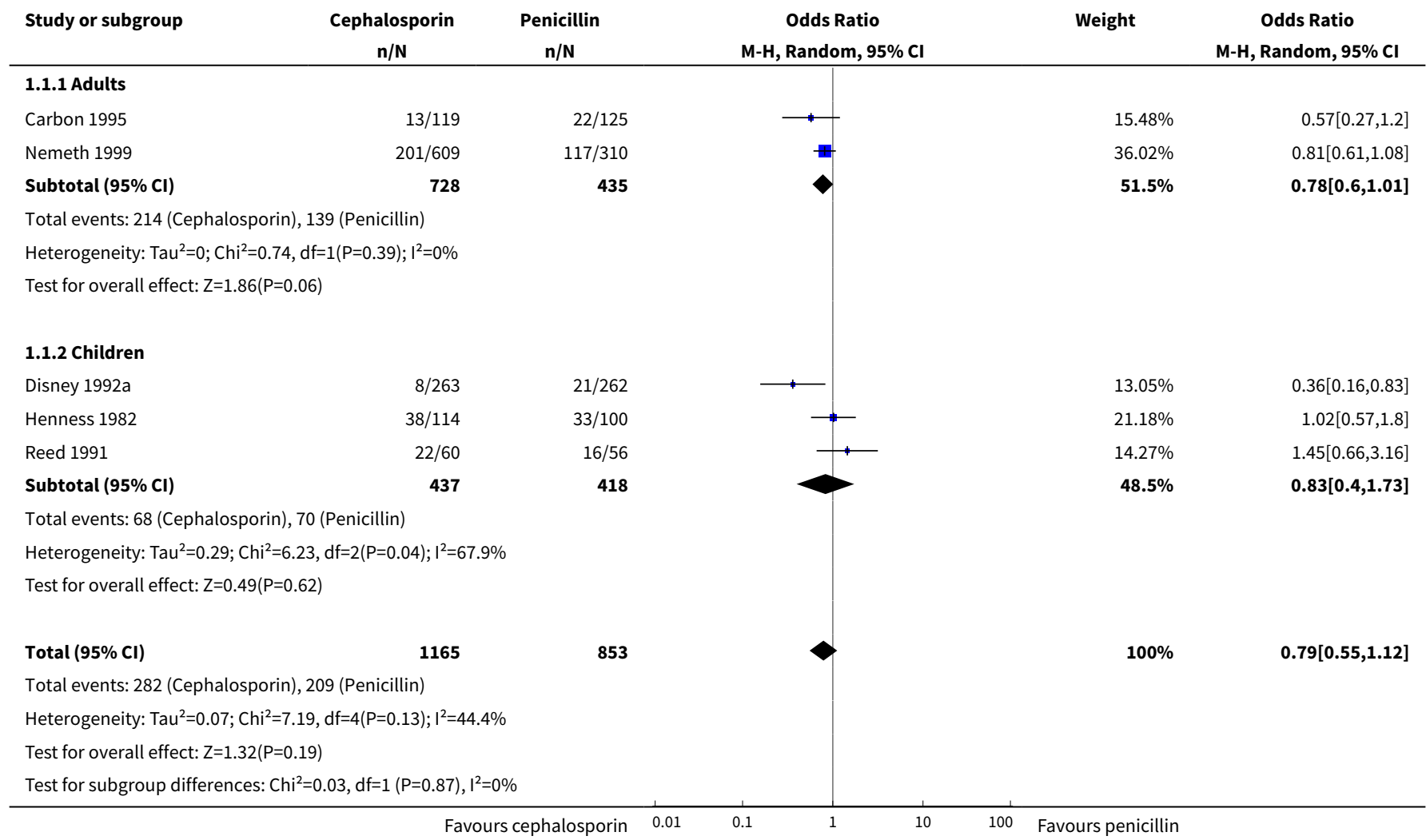

Analysis 1.2. Comparison 1 Cephalosporin versus penicillin, Outcome 2 Resolution of symptoms post-treatment (evaluable participants).

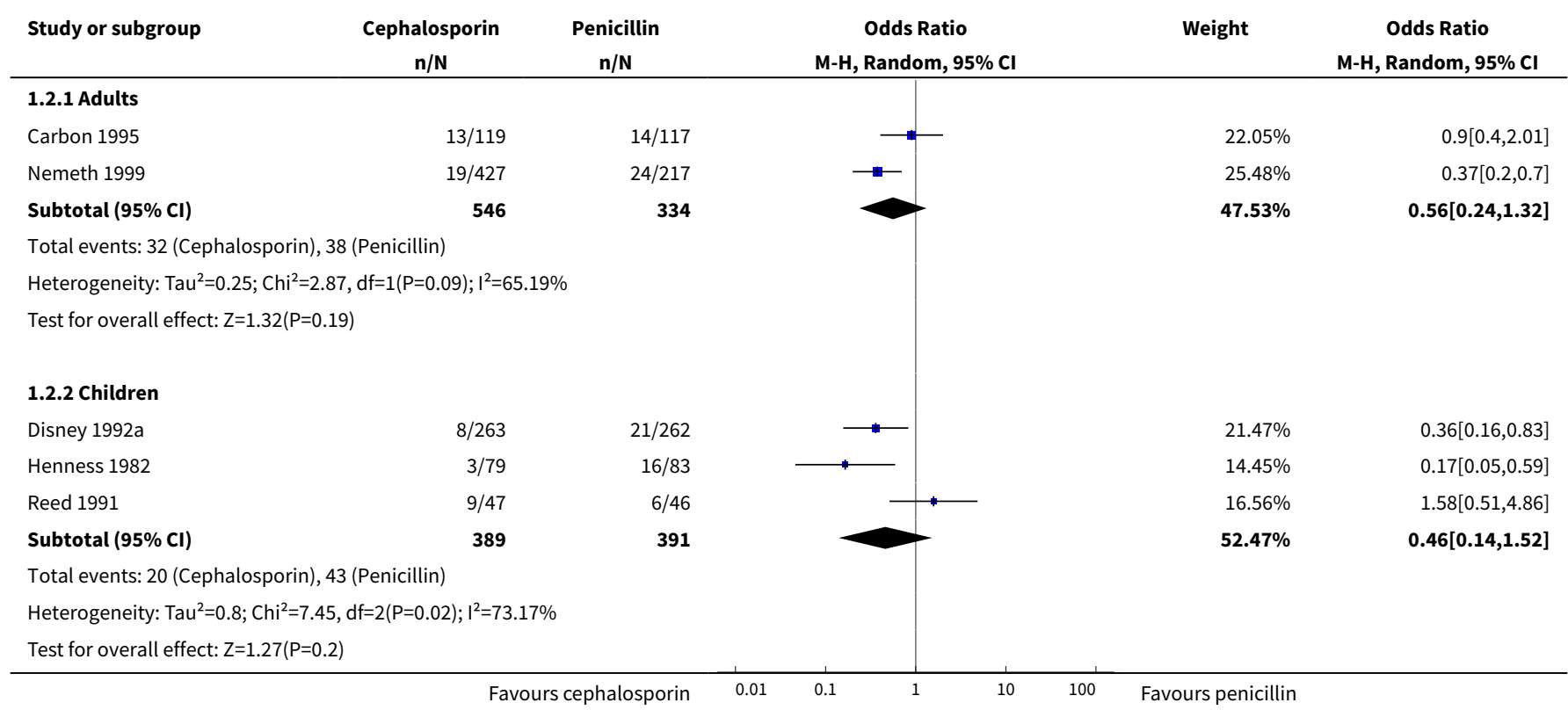




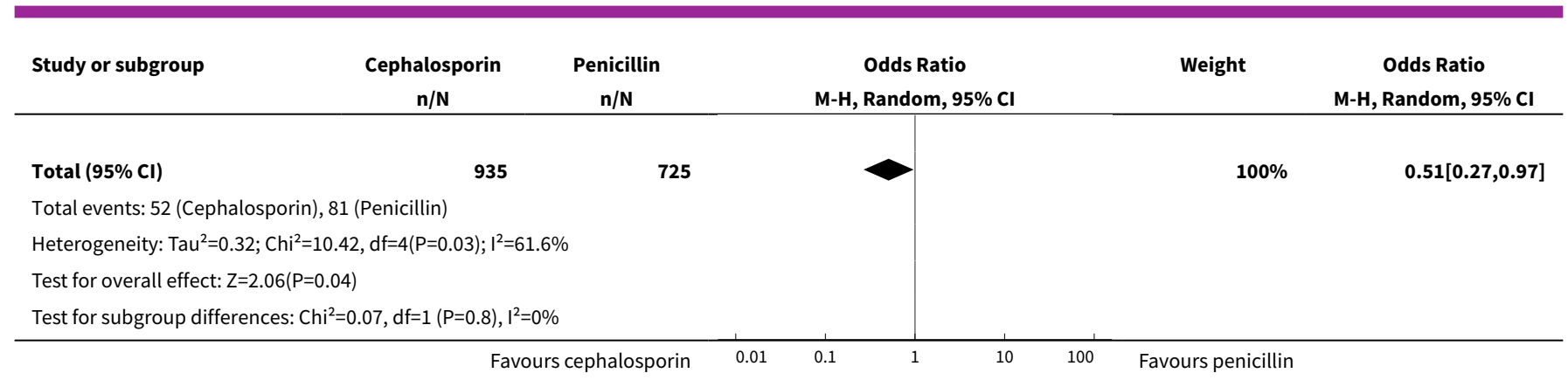

Analysis 1.3. Comparison 1 Cephalosporin versus penicillin, Outcome 3 Resolution of symptoms within 24 hours of treatment (ITT analysis).

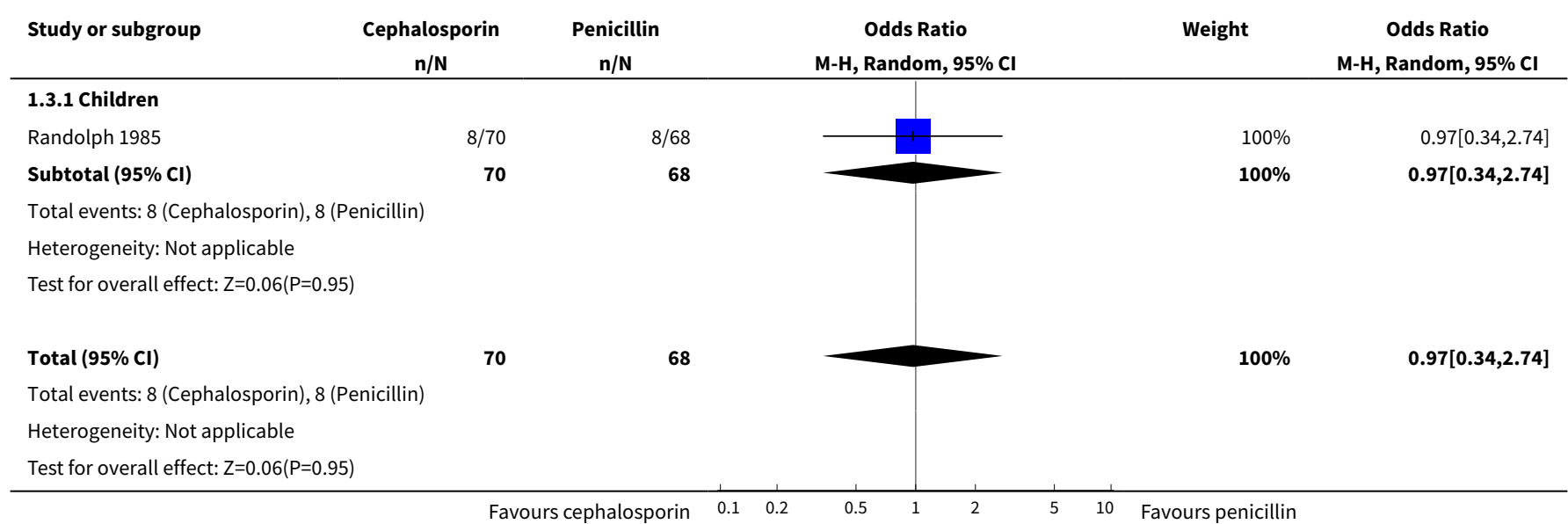

Analysis 1.4. Comparison 1 Cephalosporin versus penicillin, Outcome 4 Sore throat (ITT analysis).

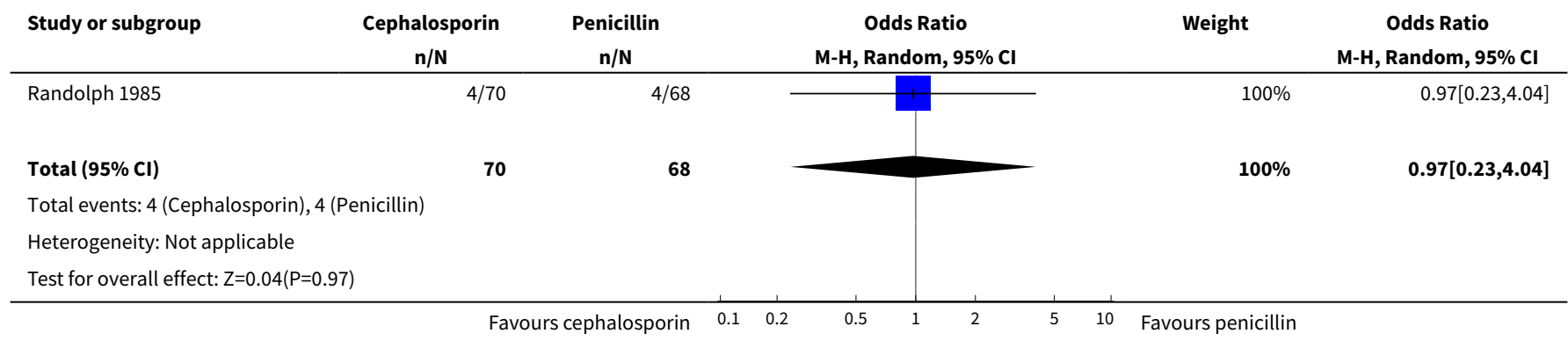

Analysis 1.5. Comparison 1 Cephalosporin versus penicillin, Outcome 5 Fever (ITT analysis).

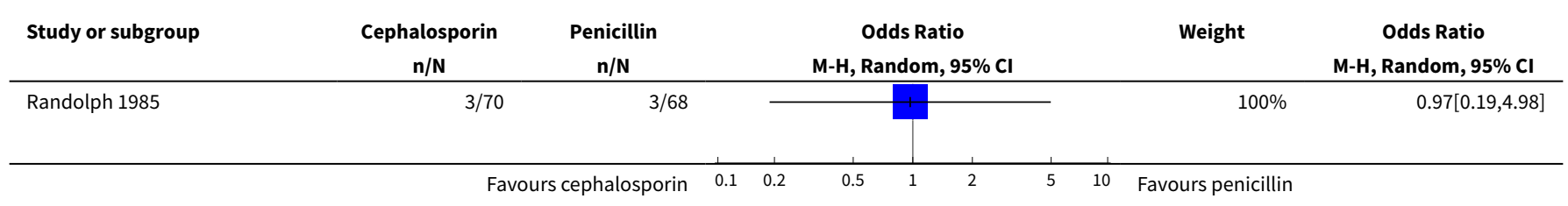




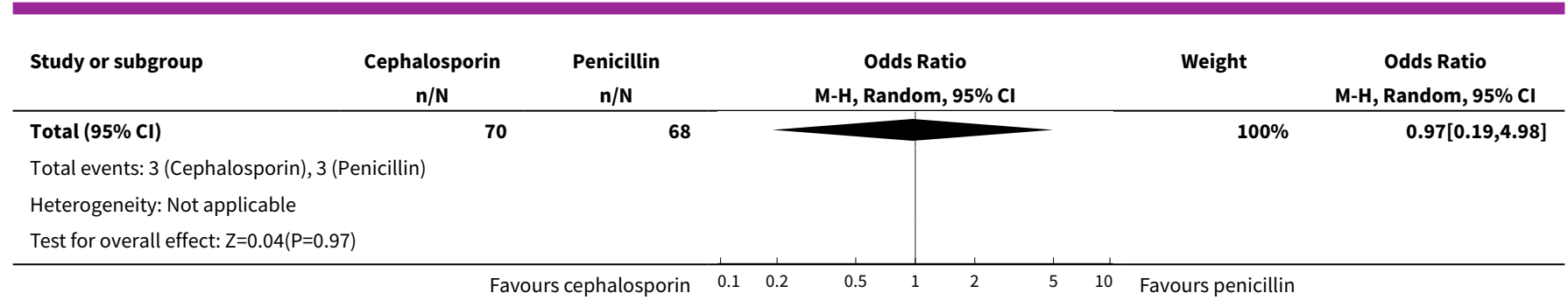

\section{Analysis 1.6. Comparison 1 Cephalosporin versus penicillin,} Outcome 6 Incidence of relapse (evaluable participants).

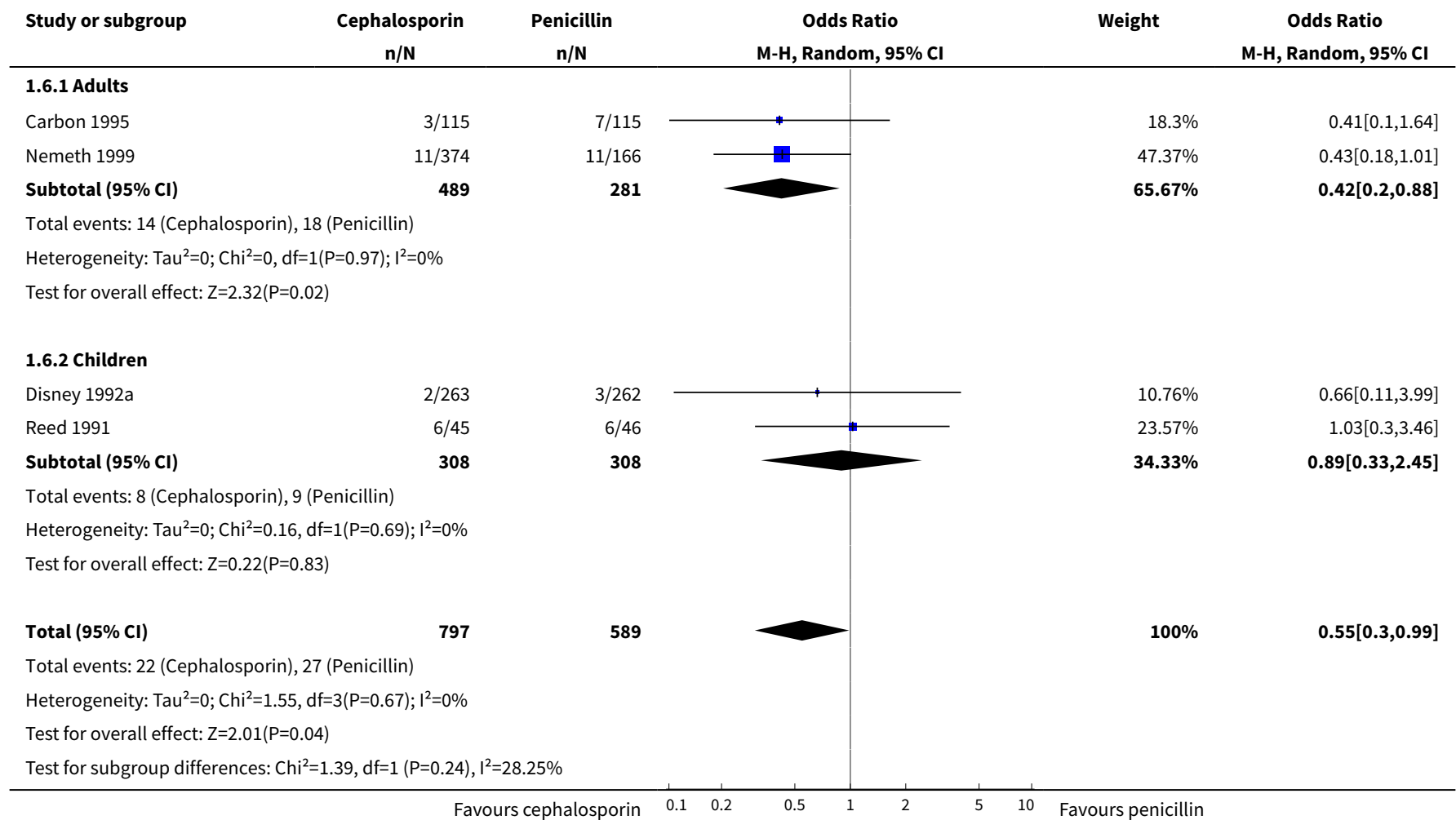

Analysis 1.7. Comparison 1 Cephalosporin versus penicillin, Outcome 7 Complications (ITT analysis).

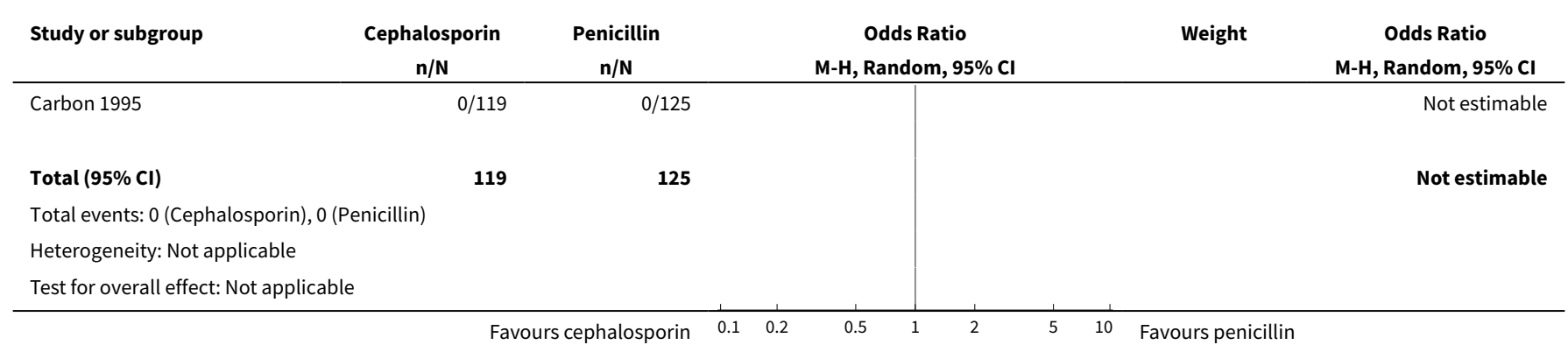


Analysis 1.8. Comparison 1 Cephalosporin versus penicillin, Outcome 8 Adverse events (ITT analysis).

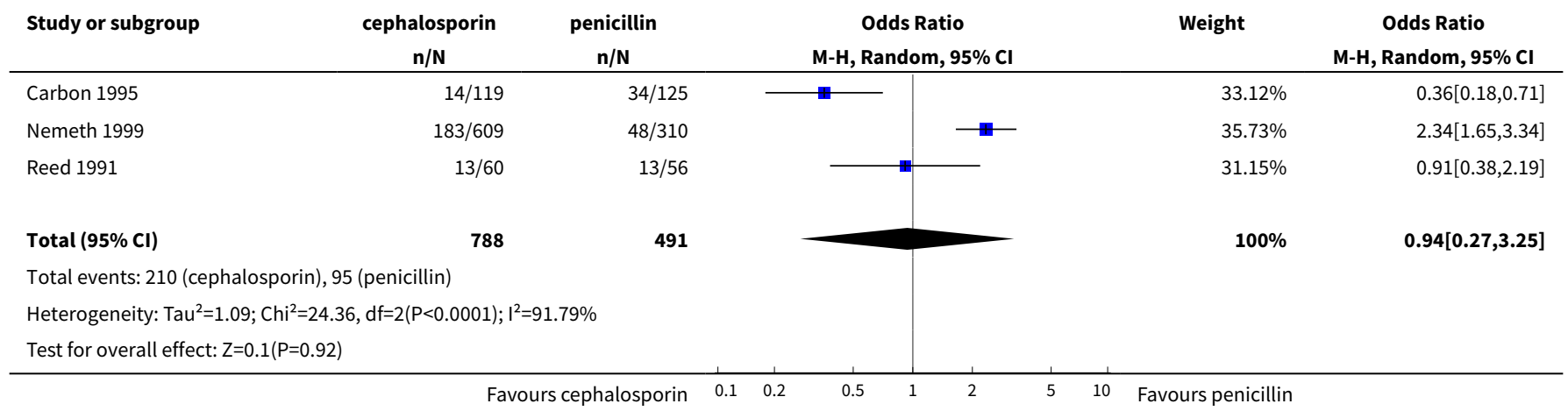

Analysis 1.9. Comparison 1 Cephalosporin versus penicillin, Outcome 9 Resolution of symptoms ITT (subgroup sponsored versus no sponsor reported).

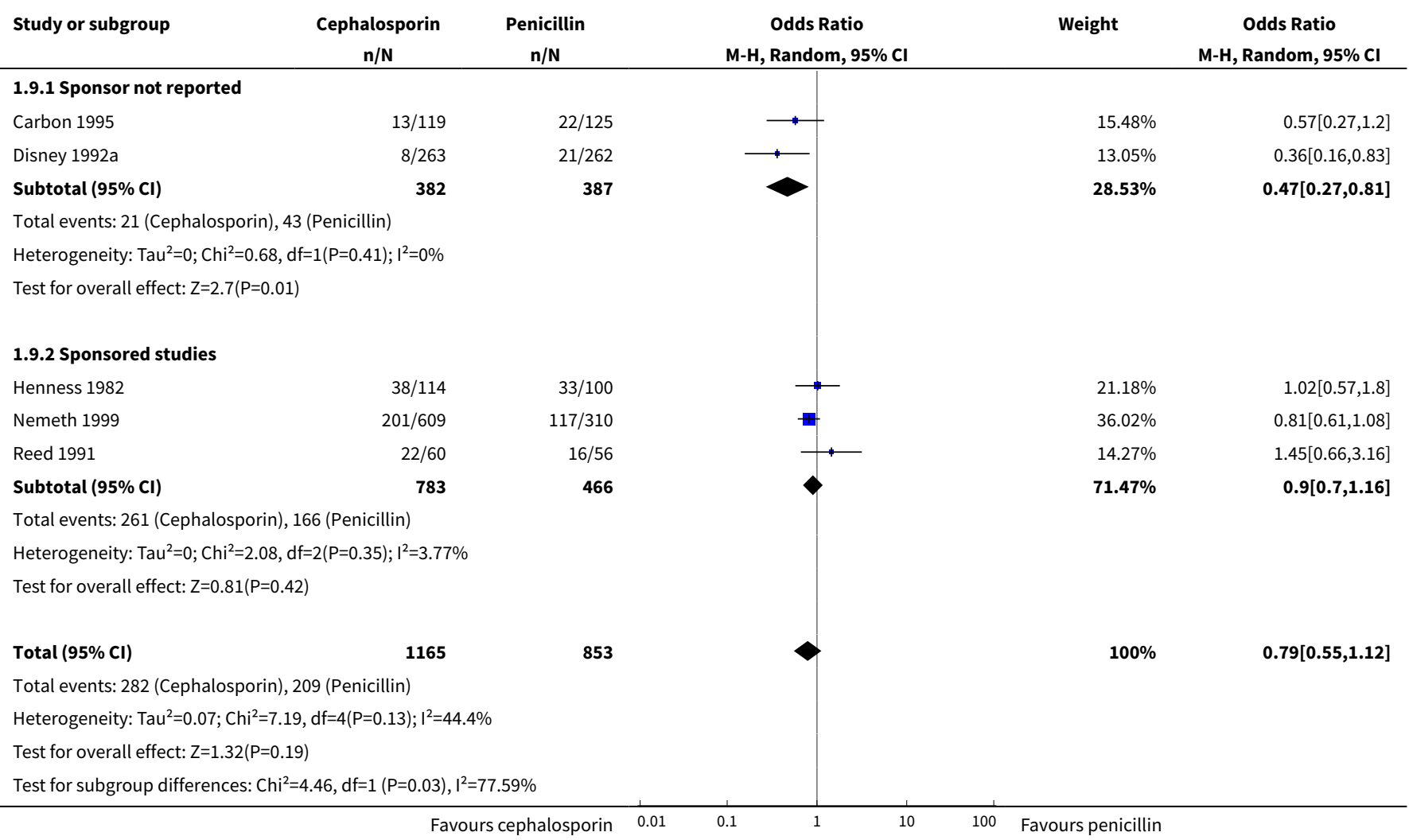


Comparison 2. Macrolide versus penicillin

\begin{tabular}{|c|c|c|c|c|}
\hline Outcome or subgroup title & $\begin{array}{l}\text { No. of } \\
\text { studies }\end{array}$ & $\begin{array}{l}\text { No. of } \\
\text { partici- } \\
\text { pants }\end{array}$ & Statistical method & Effect size \\
\hline $\begin{array}{l}1 \text { Resolution of symptoms post-treatment } \\
\text { (ITT analysis) }\end{array}$ & 6 & 1728 & $\begin{array}{l}\text { Odds Ratio (M-H, Fixed, 95\% } \\
\mathrm{Cl})\end{array}$ & $1.11[0.92,1.35]$ \\
\hline 1.1 Adults & 5 & 1239 & $\begin{array}{l}\text { Odds Ratio (M-H, Fixed, 95\% } \\
\mathrm{Cl})\end{array}$ & $1.07[0.86,1.34]$ \\
\hline 1.2 Children & 1 & 489 & $\begin{array}{l}\text { Odds Ratio (M-H, Fixed, 95\% } \\
\mathrm{Cl} \text { ) }\end{array}$ & $1.25[0.85,1.84]$ \\
\hline $\begin{array}{l}2 \text { Resolution of symptoms post-treatment } \\
\text { (evaluable participants only) }\end{array}$ & 6 & 1159 & $\begin{array}{l}\text { Odds Ratio (M-H, Fixed, 95\% } \\
\mathrm{Cl})\end{array}$ & $0.79[0.57,1.09]$ \\
\hline 2.1 Adults & 5 & 801 & $\begin{array}{l}\text { Odds Ratio (M-H, Fixed, 95\% } \\
\mathrm{Cl})\end{array}$ & $0.88[0.59,1.31]$ \\
\hline 2.2 Children & 1 & 358 & $\begin{array}{l}\text { Odds Ratio (M-H, Fixed, 95\% } \\
\mathrm{Cl})\end{array}$ & $0.64[0.36,1.11]$ \\
\hline 3 Sore throat post-treatment (ITT analysis) & 2 & 371 & $\begin{array}{l}\text { Odds Ratio (M-H, Fixed, 95\% } \\
\mathrm{Cl})\end{array}$ & $0.97[0.64,1.46]$ \\
\hline 4 Fever post-treatment (ITT analysis) & 2 & 371 & $\begin{array}{l}\text { Odds Ratio (M-H, Fixed, 95\% } \\
\mathrm{Cl} \text { ) }\end{array}$ & $1.05[0.69,1.59]$ \\
\hline $\begin{array}{l}5 \text { Incidence of relapse (evaluable partici- } \\
\text { pants) }\end{array}$ & 6 & 802 & $\begin{array}{l}\text { Odds Ratio (M-H, Random, } \\
95 \% \mathrm{Cl})\end{array}$ & $1.21[0.48,3.03]$ \\
\hline 5.1 Adults & 5 & 495 & $\begin{array}{l}\text { Odds Ratio (M-H, Random, } \\
95 \% \mathrm{Cl})\end{array}$ & $0.90[0.34,2.39]$ \\
\hline 5.2 Children & 1 & 307 & $\begin{array}{l}\text { Odds Ratio (M-H, Random, } \\
95 \% \mathrm{Cl})\end{array}$ & $3.10[0.67,14.25]$ \\
\hline 6 Adverse events (ITT analysis) & 6 & 1727 & $\begin{array}{l}\text { Odds Ratio (M-H, Random, } \\
95 \% \mathrm{Cl})\end{array}$ & $1.19[0.82,1.73]$ \\
\hline 6.1 Adults & 5 & 1238 & $\begin{array}{l}\text { Odds Ratio (M-H, Random, } \\
95 \% \mathrm{Cl})\end{array}$ & $1.06[0.75,1.50]$ \\
\hline 6.2 Children & 1 & 489 & $\begin{array}{l}\text { Odds Ratio (M-H, Random, } \\
95 \% \mathrm{Cl})\end{array}$ & $2.33[1.06,5.15]$ \\
\hline $\begin{array}{l}7 \text { Resolution of symptoms ITT (subgroup } \\
\text { sponsored versus no sponsor reported) }\end{array}$ & 6 & 1728 & $\begin{array}{l}\text { Odds Ratio (M-H, Fixed, 95\% } \\
\mathrm{Cl})\end{array}$ & $1.11[0.92,1.35]$ \\
\hline 7.1 Sponsor not reported & 3 & 860 & $\begin{array}{l}\text { Odds Ratio (M-H, Fixed, 95\% } \\
\mathrm{Cl})\end{array}$ & $1.11[0.84,1.48]$ \\
\hline 7.2 Sponsored studies & 3 & 868 & $\begin{array}{l}\text { Odds Ratio (M-H, Fixed, 95\% } \\
\mathrm{Cl})\end{array}$ & $1.12[0.85,1.46]$ \\
\hline
\end{tabular}




\section{Analysis 2.1. Comparison 2 Macrolide versus penicillin, Outcome} 1 Resolution of symptoms post-treatment (ITT analysis).

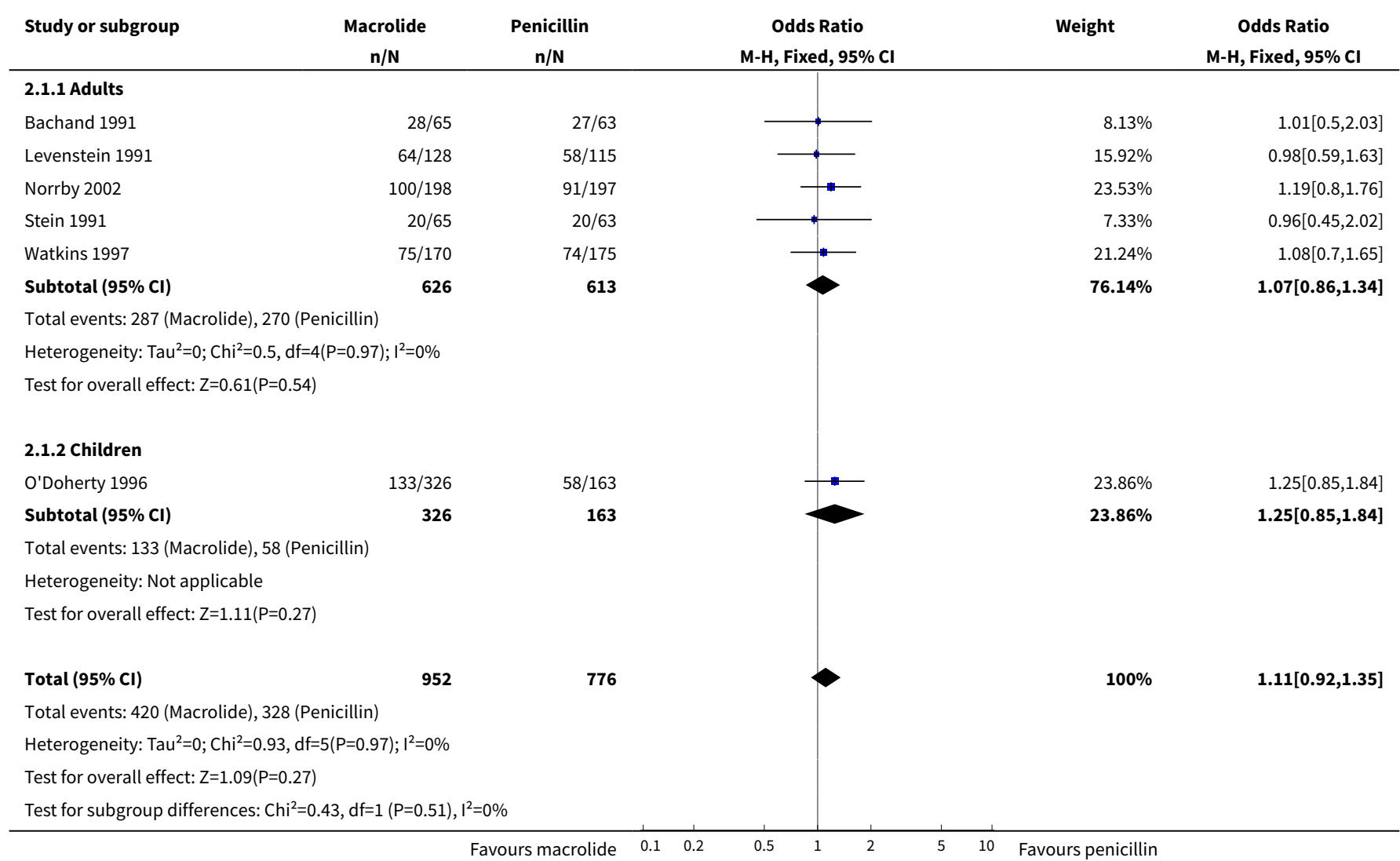

Analysis 2.2. Comparison 2 Macrolide versus penicillin, Outcome 2 Resolution of symptoms post-treatment (evaluable participants only).

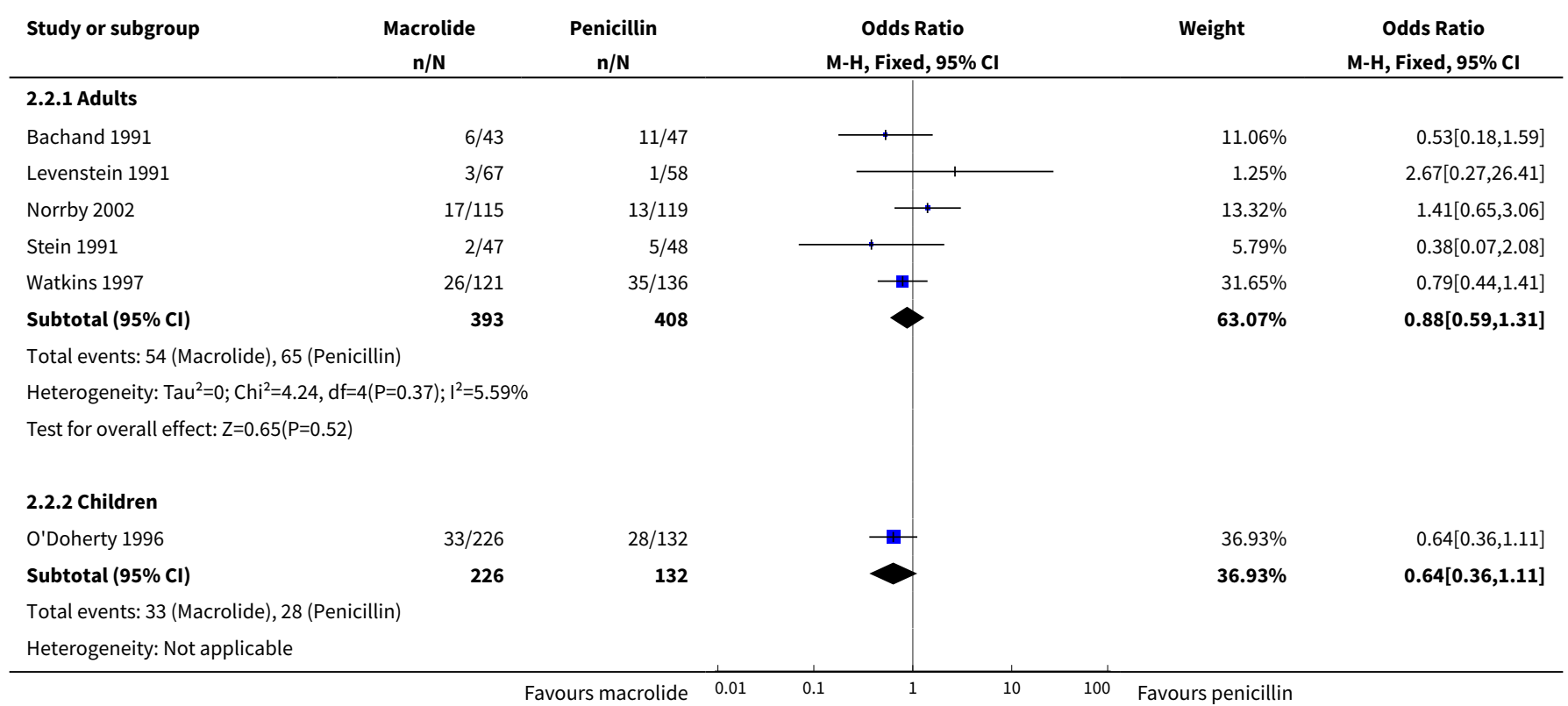




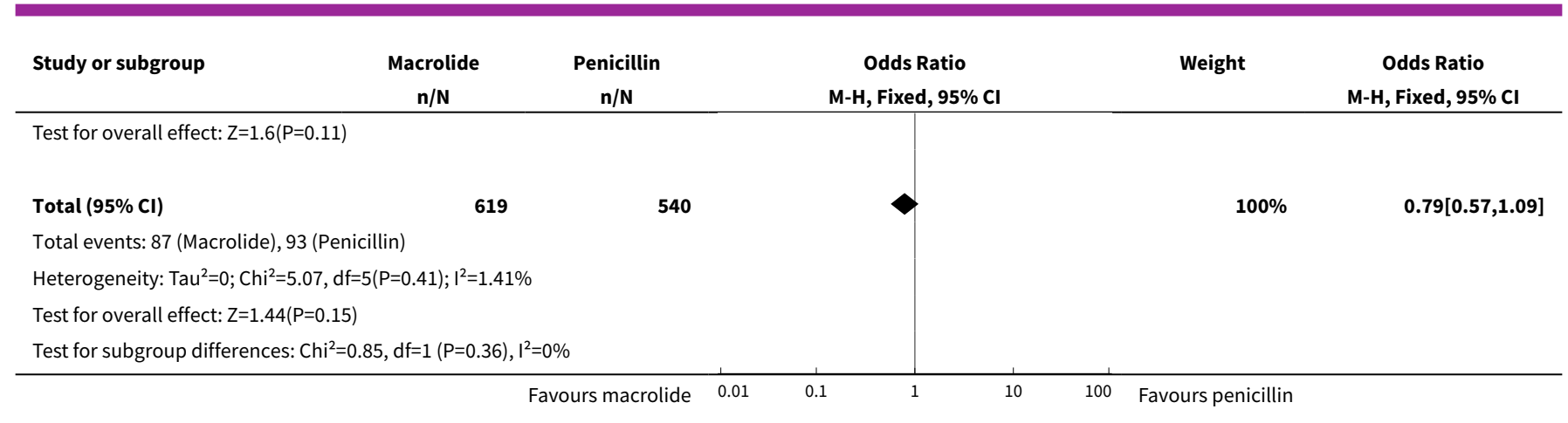

Analysis 2.3. Comparison 2 Macrolide versus penicillin, Outcome 3 Sore throat post-treatment (ITT analysis).

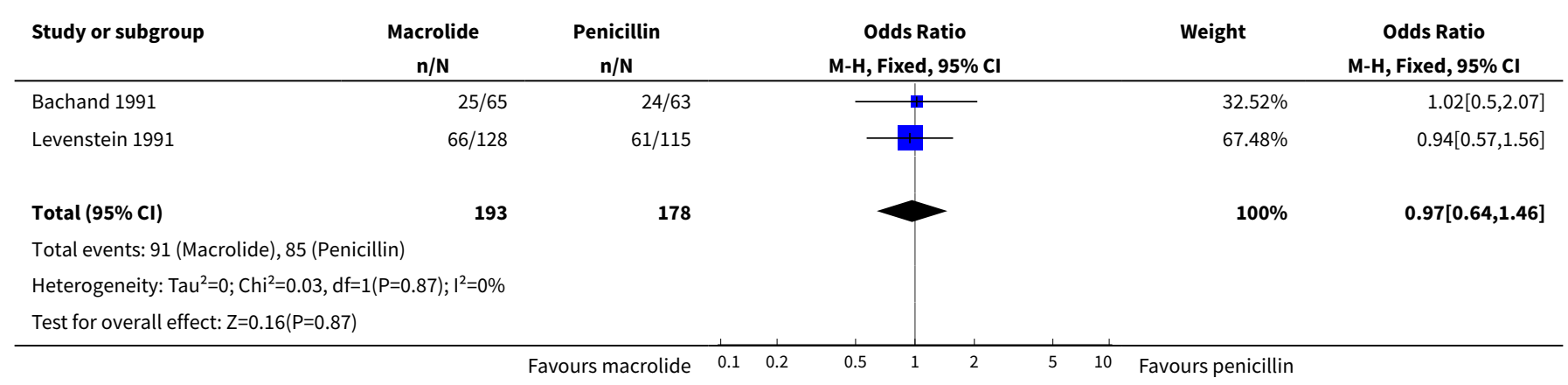

Analysis 2.4. Comparison 2 Macrolide versus penicillin, Outcome 4 Fever post-treatment (ITT analysis).

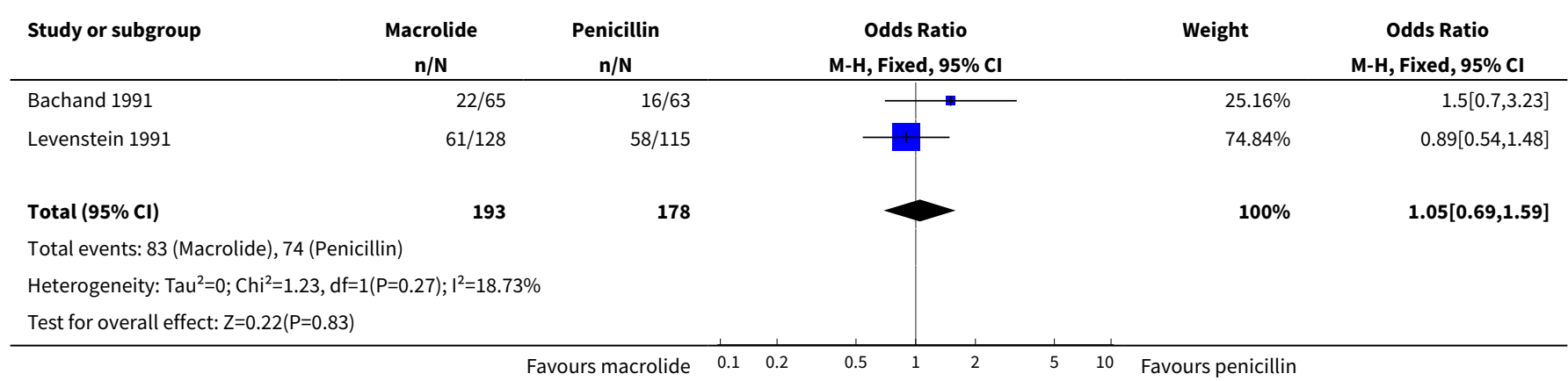

Analysis 2.5. Comparison 2 Macrolide versus penicillin, Outcome 5 Incidence of relapse (evaluable participants).

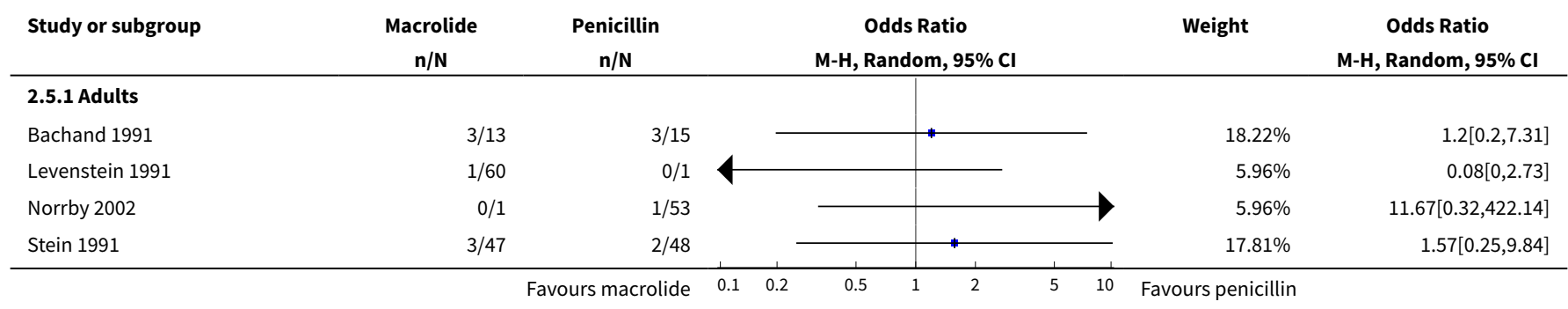




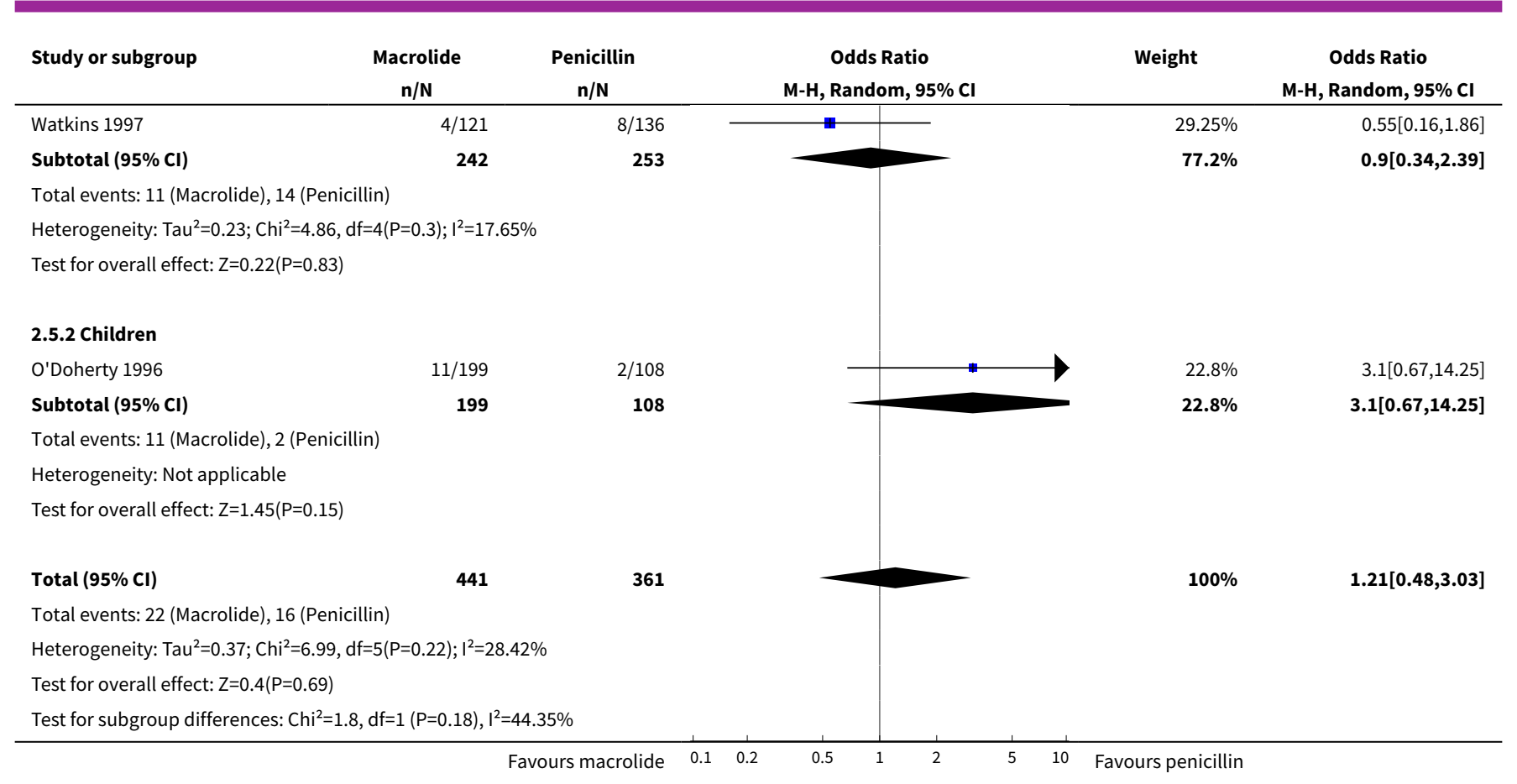

Analysis 2.6. Comparison 2 Macrolide versus penicillin, Outcome 6 Adverse events (ITT analysis).

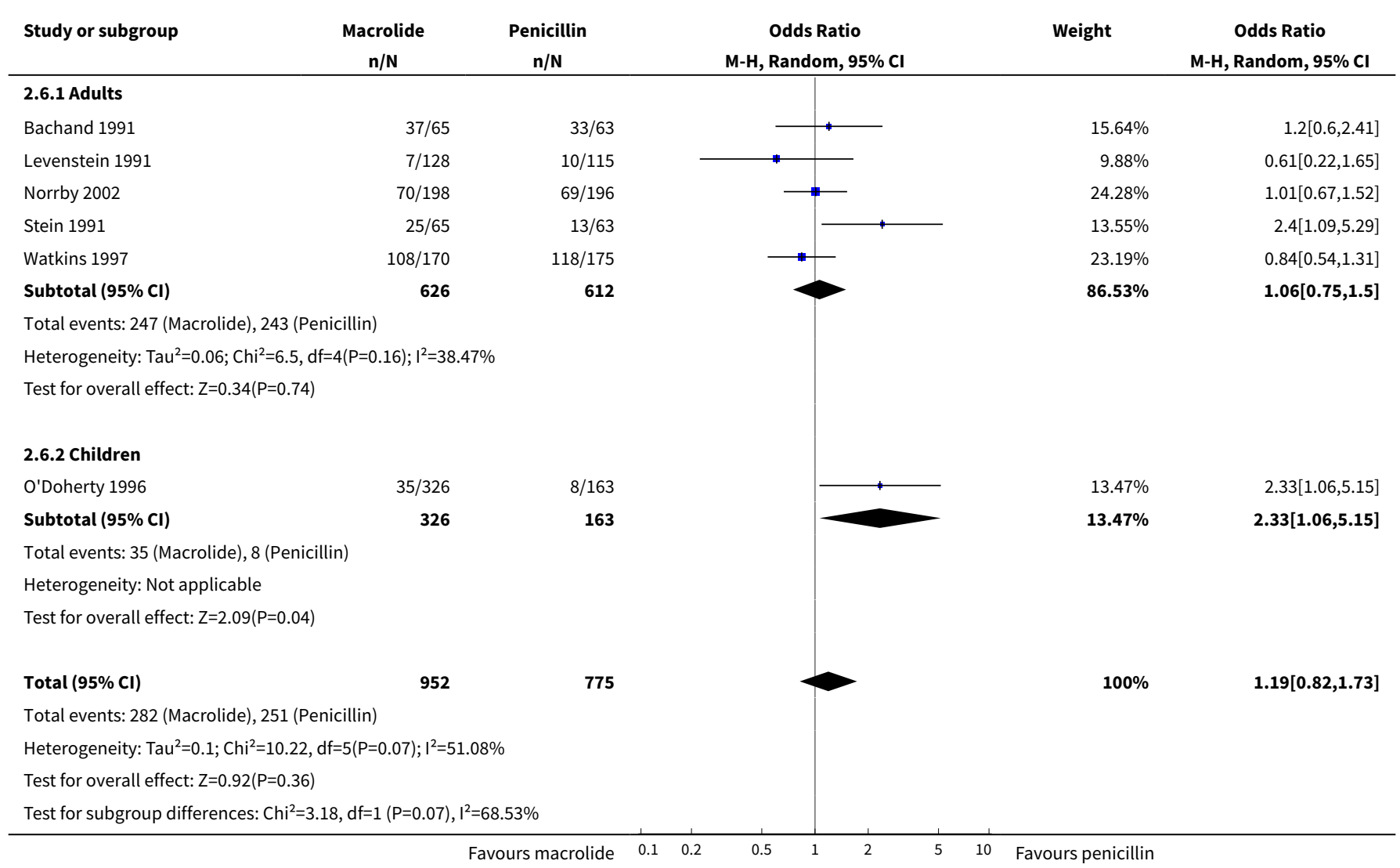




\section{Analysis 2.7. Comparison 2 Macrolide versus penicillin, Outcome 7 Resolution of symptoms ITT (subgroup sponsored versus no sponsor reported).}

\begin{tabular}{|c|c|c|c|c|c|}
\hline Study or subgroup & $\begin{array}{c}\text { Macrolide } \\
\mathrm{n} / \mathrm{N} \\
\end{array}$ & $\begin{array}{c}\text { Penicillin } \\
\mathrm{n} / \mathrm{N}\end{array}$ & $\begin{array}{c}\text { Odds Ratio } \\
\text { M-H, Fixed, 95\% Cl }\end{array}$ & Weight & $\begin{array}{c}\text { Odds Ratio } \\
\text { M-H, Fixed, 95\% Cl }\end{array}$ \\
\hline \multicolumn{6}{|c|}{ 2.7.1 Sponsor not reported } \\
\hline Levenstein 1991 & $64 / 128$ & $58 / 115$ & $\rightarrow$ & $15.92 \%$ & $0.98[0.59,1.63]$ \\
\hline O'Doherty 1996 & $133 / 326$ & $58 / 163$ & - & $23.86 \%$ & $1.25[0.85,1.84]$ \\
\hline Stein 1991 & $20 / 65$ & $20 / 63$ & - & $7.33 \%$ & $0.96[0.45,2.02]$ \\
\hline Subtotal $(95 \% \mathrm{CI})$ & 519 & 341 & & $47.1 \%$ & $1.11[0.84,1.48]$ \\
\hline \multicolumn{6}{|c|}{ Heterogeneity: $\mathrm{Tau}^{2}=0 ; \mathrm{Chi}^{2}=0.72, \mathrm{df}=2(\mathrm{P}=0.7) ; \mathrm{I}^{2}=0 \%$} \\
\hline \multicolumn{6}{|c|}{ Test for overall effect: $Z=0.74(P=0.46)$} \\
\hline \multicolumn{6}{|c|}{ 2.7.2 Sponsored studies } \\
\hline Bachand 1991 & $28 / 65$ & $27 / 63$ & $\longrightarrow$ & $8.13 \%$ & $1.01[0.5,2.03]$ \\
\hline Norrby 2002 & $100 / 198$ & $91 / 197$ & - & $23.53 \%$ & $1.19[0.8,1.76]$ \\
\hline Subtotal $(95 \% \mathrm{Cl})$ & 433 & 435 & & $52.9 \%$ & $1.12[0.85,1.46]$ \\
\hline \multicolumn{6}{|c|}{ Total events: 203 (Macrolide), 192 (Penicillin) } \\
\hline \multicolumn{6}{|c|}{ Heterogeneity: $\operatorname{Tau}^{2}=0 ; \mathrm{Chi}^{2}=0.2, \mathrm{df}=2(\mathrm{P}=0.9) ; \mathrm{I}^{2}=0 \%$} \\
\hline \multicolumn{6}{|c|}{ Test for overall effect: $Z=0.81(P=0.42)$} \\
\hline Total $(95 \% \mathrm{Cl})$ & 952 & 776 & 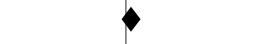 & $100 \%$ & $1.11[0.92,1.35]$ \\
\hline \multicolumn{6}{|c|}{ Total events: 420 (Macrolide), 328 (Penicillin) } \\
\hline \multicolumn{6}{|c|}{ Heterogeneity: $\operatorname{Tau}^{2}=0 ; \mathrm{Chi}^{2}=0.93, \mathrm{df}=5(\mathrm{P}=0.97) ; \mathrm{I}^{2}=0 \%$} \\
\hline \multicolumn{6}{|c|}{ Test for overall effect: $Z=1.09(P=0.27)$} \\
\hline Test for subgroup dif & $f=1(P=0.99), I^{2}=$ & & & & \\
\hline
\end{tabular}

Comparison 3. Azithromycin versus amoxicillin

\begin{tabular}{|c|c|c|c|c|}
\hline Outcome or subgroup title & $\begin{array}{l}\text { No. of } \\
\text { studies }\end{array}$ & $\begin{array}{l}\text { No. of } \\
\text { partici- } \\
\text { pants }\end{array}$ & Statistical method & Effect size \\
\hline 1 Clinical cure at $24-28$ days (ITT) & 1 & 673 & $\begin{array}{l}\text { Odds Ratio (M-H, Fixed, 95\% } \\
\mathrm{Cl})\end{array}$ & $0.76[0.55,1.05]$ \\
\hline 1.1 Children & 1 & 673 & $\begin{array}{l}\text { Odds Ratio (M-H, Fixed, 95\% } \\
\mathrm{Cl})\end{array}$ & $0.76[0.55,1.05]$ \\
\hline $\begin{array}{l}2 \text { Clinical cure at } 24-28 \text { days (bacteriologi- } \\
\text { cal per protocol population) }\end{array}$ & 1 & 482 & $\begin{array}{l}\text { Odds Ratio (M-H, Fixed, 95\% } \\
\mathrm{Cl})\end{array}$ & $0.29[0.11,0.73]$ \\
\hline 2.1 Children & 1 & 482 & $\begin{array}{l}\text { Odds Ratio (M-H, Fixed, 95\% } \\
\mathrm{Cl})\end{array}$ & $0.29[0.11,0.73]$ \\
\hline 3 Relapse on day 38-45 (ITT) & 1 & 673 & $\begin{array}{l}\text { Odds Ratio (M-H, Fixed, 95\% } \\
\mathrm{Cl})\end{array}$ & $0.75[0.55,1.02]$ \\
\hline 3.1 Children & 1 & 673 & $\begin{array}{l}\text { Odds Ratio (M-H, Fixed, 95\% } \\
\mathrm{Cl})\end{array}$ & $0.75[0.55,1.02]$ \\
\hline
\end{tabular}




\begin{tabular}{lllll}
\hline Outcome or subgroup title & $\begin{array}{l}\text { No. of } \\
\text { studies }\end{array}$ & $\begin{array}{l}\text { No. of } \\
\text { partici- } \\
\text { pants }\end{array}$ & Statistical method & Effect size \\
\hline $\begin{array}{l}4 \text { Relapse on day 38-45 (bacteriological per } \\
\text { protocol) }\end{array}$ & 1 & 422 & $\begin{array}{l}\text { Odds Ratio (M-H, Fixed, 95\% } \\
\text { Cl) }\end{array}$ & $0.88[0.43,1.82]$ \\
\hline 4.1 Children & 1 & 422 & $\begin{array}{l}\text { Odds Ratio (M-H, Fixed, 95\% } \\
\text { Cl) }\end{array}$ & $0.88[0.43,1.82]$ \\
\hline 5 Adverse events (all patients) & 1 & 673 & $\begin{array}{l}\text { Odds Ratio (M-H, Fixed, 95\% } \\
\text { Cl) }\end{array}$ & $2.67[1.78,3.99]$ \\
\hline 5.1 Children & 1 & 673 & $\begin{array}{l}\text { Odds Ratio (M-H, Fixed, 95\% } \\
\text { Cl) }\end{array}$ & $2.67[1.78,3.99]$ \\
\hline
\end{tabular}

Analysis 3.1. Comparison 3 Azithromycin versus amoxicillin, Outcome 1 Clinical cure at 24-28 days (ITT).

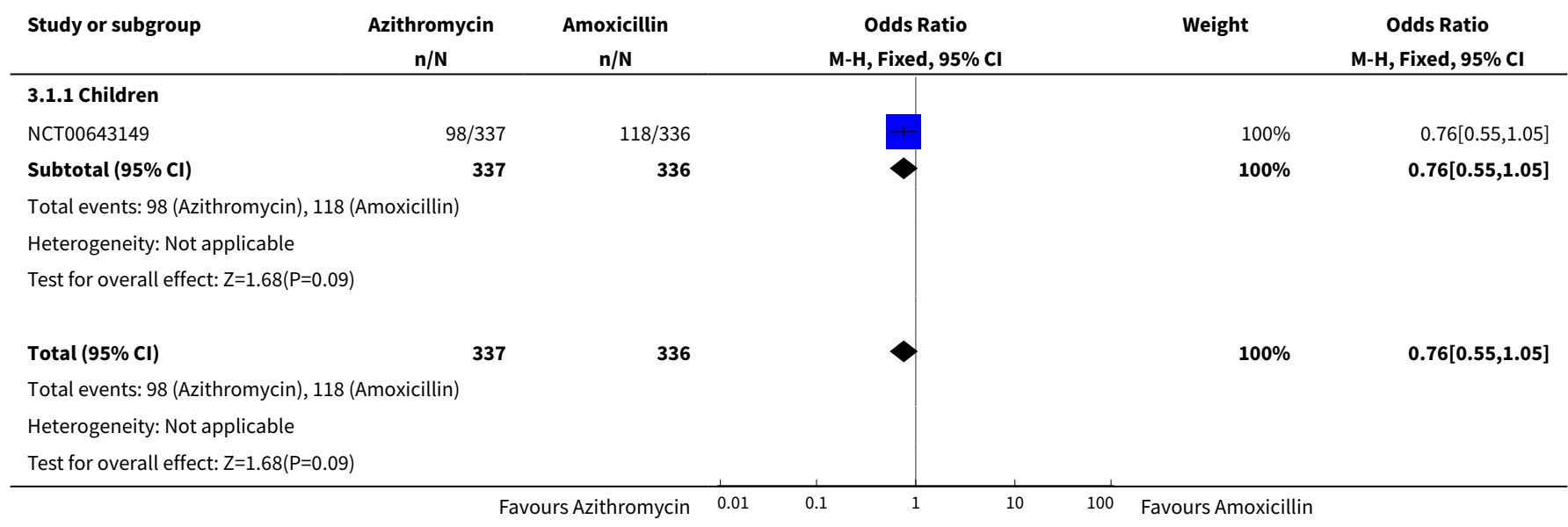

Analysis 3.2. Comparison 3 Azithromycin versus amoxicillin, Outcome 2 Clinical cure at 24-28 days (bacteriological per protocol population).

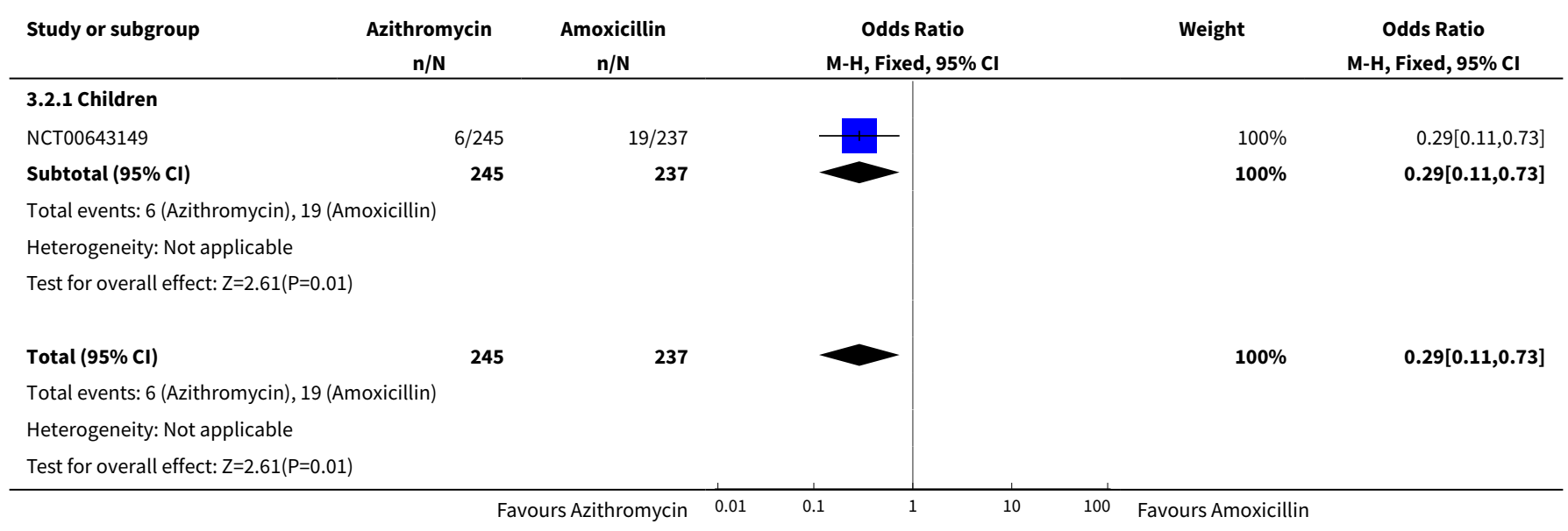


Analysis 3.3. Comparison 3 Azithromycin versus amoxicillin, Outcome 3 Relapse on day 38-45 (ITT).

\begin{tabular}{|c|c|c|c|c|c|}
\hline Study or subgroup & $\begin{array}{c}\text { Azithromycin } \\
n / N\end{array}$ & $\begin{array}{c}\text { Amoxicillin } \\
n / N\end{array}$ & $\begin{array}{c}\text { Odds Ratio } \\
\text { M-H, Fixed, } 95 \% \mathrm{CI}\end{array}$ & Weight & $\begin{array}{c}\text { Odds Ratio } \\
\text { M-H, Fixed, } 95 \% \mathrm{Cl}\end{array}$ \\
\hline \multicolumn{6}{|l|}{ 3.3.1 Children } \\
\hline NCT00643149 & $130 / 337$ & $153 / 336$ & & $100 \%$ & $0.75[0.55,1.02]$ \\
\hline Subtotal $(95 \% \mathrm{Cl})$ & 337 & 336 & $\Delta$ & $100 \%$ & $0.75[0.55,1.02]$ \\
\hline \multicolumn{6}{|c|}{ Total events: 130 (Azithromycin), 153 (Amoxicillin) } \\
\hline \multicolumn{6}{|c|}{ Heterogeneity: Not applicable } \\
\hline \multicolumn{6}{|c|}{ Test for overall effect: $Z=1.83(P=0.07)$} \\
\hline Total $(95 \% \mathrm{Cl})$ & 337 & 336 & $\Delta$ & $100 \%$ & $0.75[0.55,1.02]$ \\
\hline \multicolumn{6}{|c|}{ Total events: 130 (Azithromycin), 153 (Amoxicillin) } \\
\hline \multicolumn{6}{|c|}{ Heterogeneity: Not applicable } \\
\hline \multicolumn{6}{|c|}{ Test for overall effect: $\mathrm{Z}=1.83(\mathrm{P}=0.07)$} \\
\hline
\end{tabular}

Analysis 3.4. Comparison 3 Azithromycin versus amoxicillin, Outcome 4 Relapse on day 38-45 (bacteriological per protocol).

\begin{tabular}{|c|c|c|c|c|c|}
\hline Study or subgroup & $\begin{array}{c}\text { Azithromycin } \\
n / N\end{array}$ & $\begin{array}{c}\text { Amoxicillin } \\
\mathrm{n} / \mathrm{N}\end{array}$ & $\begin{array}{c}\text { Odds Ratio } \\
\text { M-H, Fixed, 95\% Cl }\end{array}$ & Weight & $\begin{array}{c}\text { Odds Ratio } \\
\text { M-H, Fixed, 95\% Cl }\end{array}$ \\
\hline \multicolumn{6}{|l|}{ 3.4.1 Children } \\
\hline NCT00643149 & $16 / 223$ & $16 / 199$ & & $100 \%$ & $0.88[0.43,1.82]$ \\
\hline Subtotal $(95 \% \mathrm{CI})$ & 223 & 199 & & $100 \%$ & $0.88[0.43,1.82]$ \\
\hline \multicolumn{6}{|c|}{ Total events: 16 (Azithromycin), 16 (Amoxicillin) } \\
\hline \multicolumn{6}{|c|}{ Heterogeneity: Not applicable } \\
\hline Total $(95 \% \mathrm{Cl})$ & 223 & 199 & & $100 \%$ & $0.88[0.43,1.82]$ \\
\hline \multicolumn{6}{|c|}{ Total events: 16 (Azithromycin), 16 (Amoxicillin) } \\
\hline \multicolumn{6}{|c|}{ Heterogeneity: Not applicable } \\
\hline Test for overall effect & & & & & \\
\hline
\end{tabular}

\section{Analysis 3.5. Comparison 3 Azithromycin versus amoxicillin, Outcome 5 Adverse events (all patients).}

\begin{tabular}{|c|c|c|c|c|c|}
\hline Study or subgroup & $\begin{array}{c}\text { Azithromycin } \\
\mathrm{n} / \mathrm{N}\end{array}$ & $\begin{array}{c}\text { Amoxicillin } \\
n / N\end{array}$ & $\begin{array}{c}\text { Odds Ratio } \\
\text { M-H, Fixed, 95\% Cl }\end{array}$ & Weight & $\begin{array}{c}\text { Odds Ratio } \\
\text { M-H, Fixed, } 95 \% \mathrm{Cl}\end{array}$ \\
\hline \multicolumn{6}{|l|}{ 3.5.1 Children } \\
\hline NCT00643149 & $93 / 337$ & $42 / 336$ & & $100 \%$ & $2.67[1.78,3.99]$ \\
\hline Subtotal $(95 \% \mathrm{Cl})$ & 337 & 336 & & $100 \%$ & $2.67[1.78,3.99]$ \\
\hline \multicolumn{6}{|c|}{ Total events: 93 (Azithromycin), 42 (Amoxicillin) } \\
\hline \multicolumn{6}{|c|}{ Heterogeneity: Not applicable } \\
\hline Total $(95 \% \mathrm{CI})$ & 337 & 336 & & $100 \%$ & $2.67[1.78,3.99]$ \\
\hline
\end{tabular}




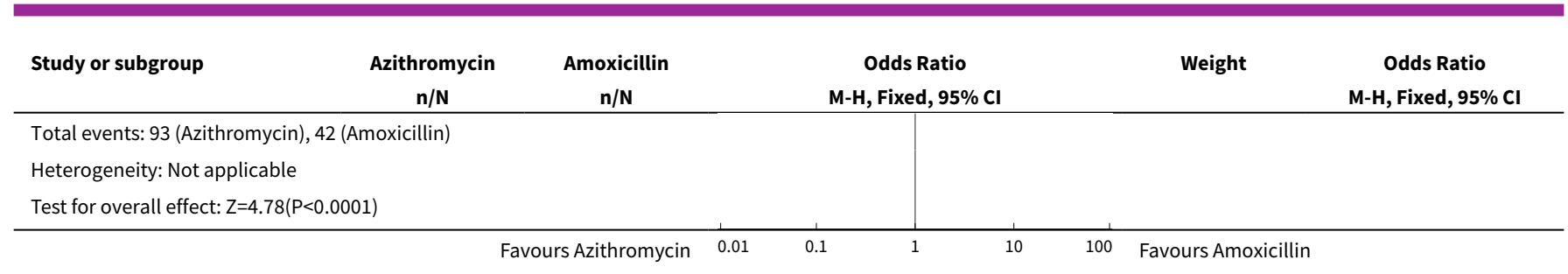

\section{Comparison 4. Carbacephem versus penicillin}

\begin{tabular}{lllll}
\hline Outcome or subgroup title & $\begin{array}{l}\text { No. of } \\
\text { studies }\end{array}$ & $\begin{array}{l}\text { No. of } \\
\text { partici- } \\
\text { pants }\end{array}$ & Statistical method & Effect size \\
\hline $\begin{array}{l}1 \text { Resolution of symptoms post-treat- } \\
\text { ment (ITT analysis) }\end{array}$ & 3 & 795 & Odds Ratio (M-H, Random, 95\% Cl) & $0.70[0.49,0.99]$ \\
\hline $\begin{array}{l}1.1 \text { Adults } \\
1.2 \text { Children }\end{array}$ & 2 & 562 & Odds Ratio (M-H, Random, 95\% Cl) & $0.75[0.46,1.22]$ \\
\hline $\begin{array}{l}2 \text { Resolution of symptoms post-treat- } \\
\text { ment (evaluable participants) }\end{array}$ & 3 & 233 & Odds Ratio (M-H, Random, 95\% Cl) & $0.57[0.33,0.99]$ \\
\hline $\begin{array}{l}2.1 \text { Adults } \\
2.2 \text { Children }\end{array}$ & 602 & Odds Ratio (M-H, Fixed, 95\% Cl) & $0.62[0.38,1.01]$ \\
\hline $\begin{array}{l}3 \text { Incidence of relapse (evaluable par- } \\
\text { ticipants) }\end{array}$ & 3 & 410 & Odds Ratio (M-H, Fixed, 95\% Cl) & $0.59[0.31,1.13]$ \\
\hline \begin{tabular}{l}
4 Adverse events (ITT analysis) \\
\hline
\end{tabular} & 3 & 523 & Odds Ratio (M-H, Fixed, 95\% Cl) & $1.27[0.64,2.50]$ \\
\hline
\end{tabular}

Analysis 4.1. Comparison 4 Carbacephem versus penicillin, Outcome 1 Resolution of symptoms post-treatment (ITT analysis).

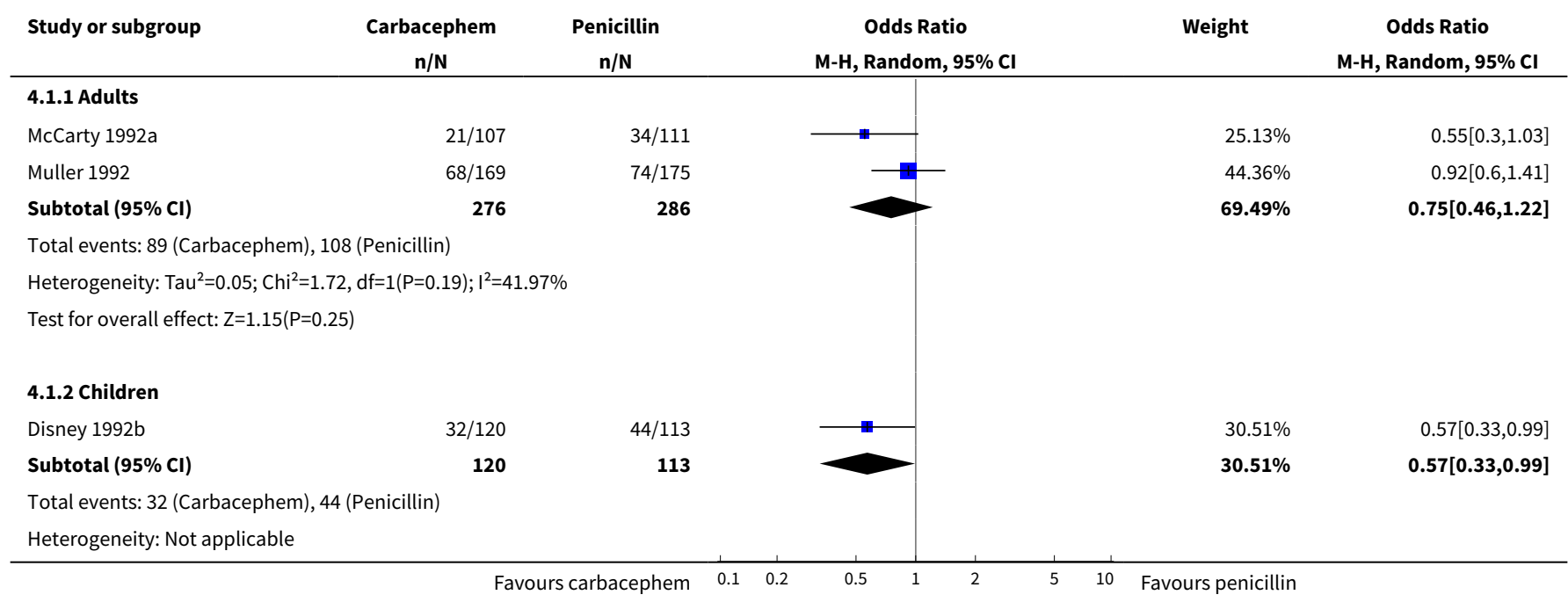




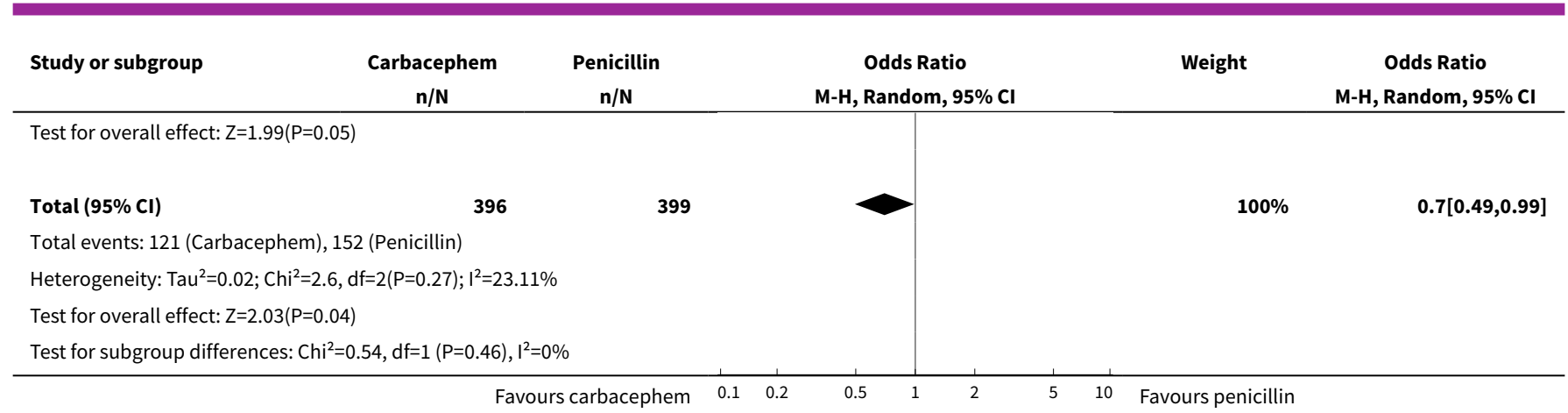

Analysis 4.2. Comparison 4 Carbacephem versus penicillin, Outcome 2 Resolution of symptoms post-treatment (evaluable participants).

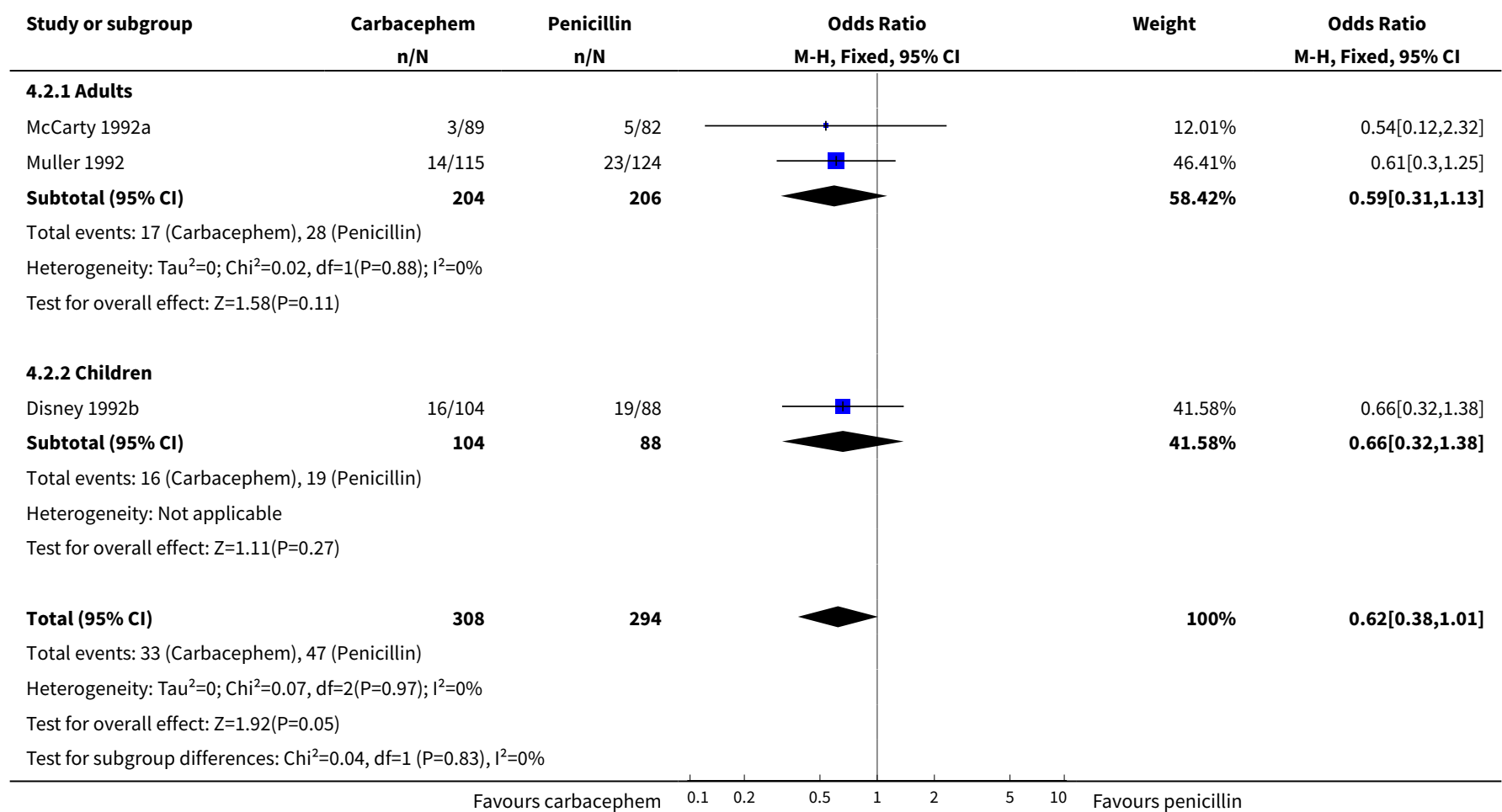

Analysis 4.3. Comparison 4 Carbacephem versus penicillin, Outcome 3 Incidence of relapse (evaluable participants).

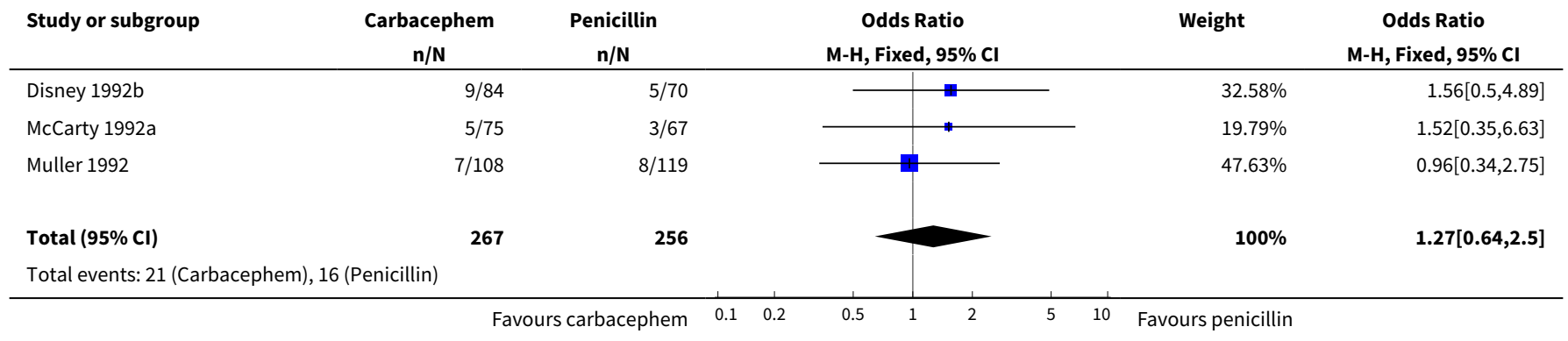




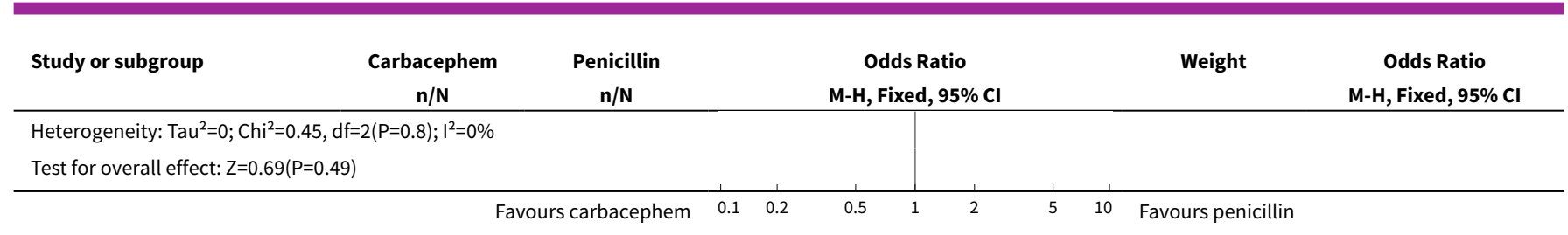

Analysis 4.4. Comparison 4 Carbacephem versus penicillin, Outcome 4 Adverse events (ITT analysis).

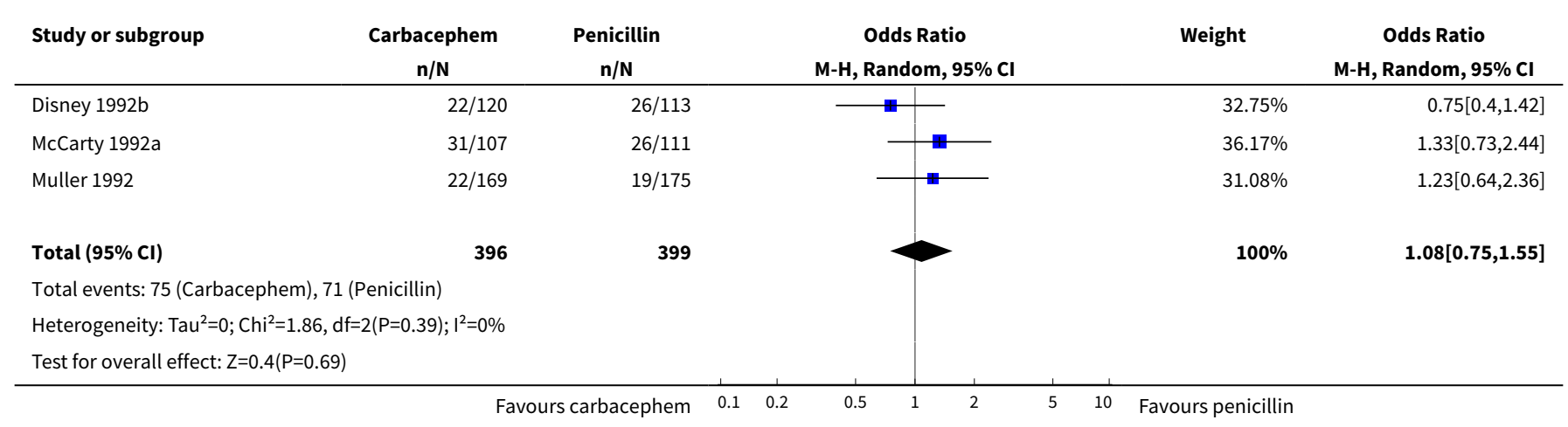

Comparison 5. Clindamycin versus ampicillin

\begin{tabular}{lllll}
\hline Outcome or subgroup title & $\begin{array}{l}\text { No. of } \\
\text { studies }\end{array}$ & $\begin{array}{l}\text { No. of partici- } \\
\text { pants }\end{array}$ & Statistical method & Effect size \\
\hline 1 Adverse events (ITT analysis) & 1 & 314 & Odds Ratio (Peto, Fixed, 95\% Cl) & $0.41[0.15,1.10]$ \\
\hline
\end{tabular}

Analysis 5.1. Comparison 5 Clindamycin versus ampicillin, Outcome 1 Adverse events (ITT analysis).

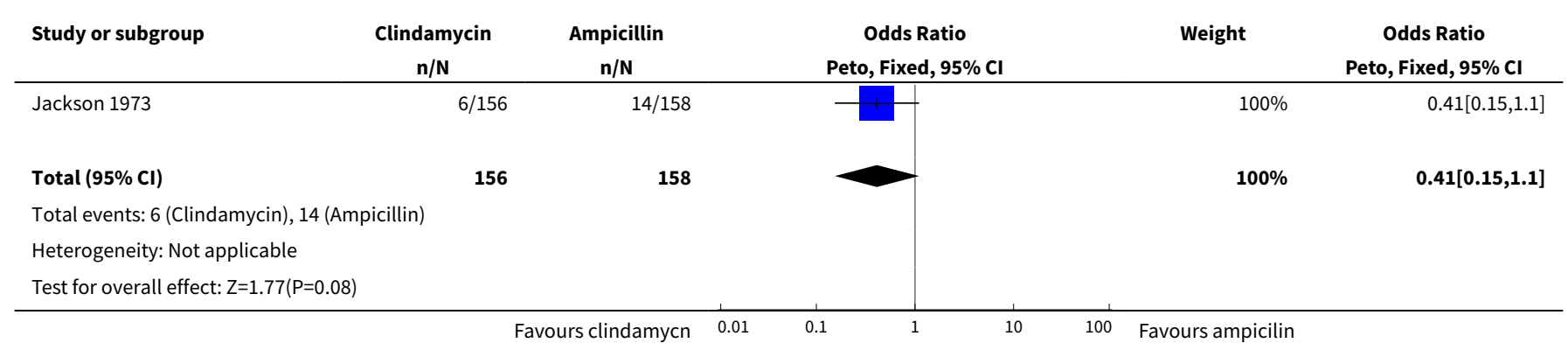

\section{Comparison 6. Sulfonamide versus penicillin}

\begin{tabular}{lllll}
\hline Outcome or subgroup title & $\begin{array}{l}\text { No. of } \\
\text { studies }\end{array}$ & $\begin{array}{l}\text { No. of par- } \\
\text { ticipants }\end{array}$ & Statistical method & Effect size \\
\hline 1 Adverse events (ITT analysis) & 1 & 87 & Odds Ratio (M-H, Fixed, 95\% Cl) & $1.37[0.43,4.34]$ \\
\hline
\end{tabular}


Analysis 6.1. Comparison 6 Sulfonamide versus penicillin, Outcome 1 Adverse events (ITT analysis).

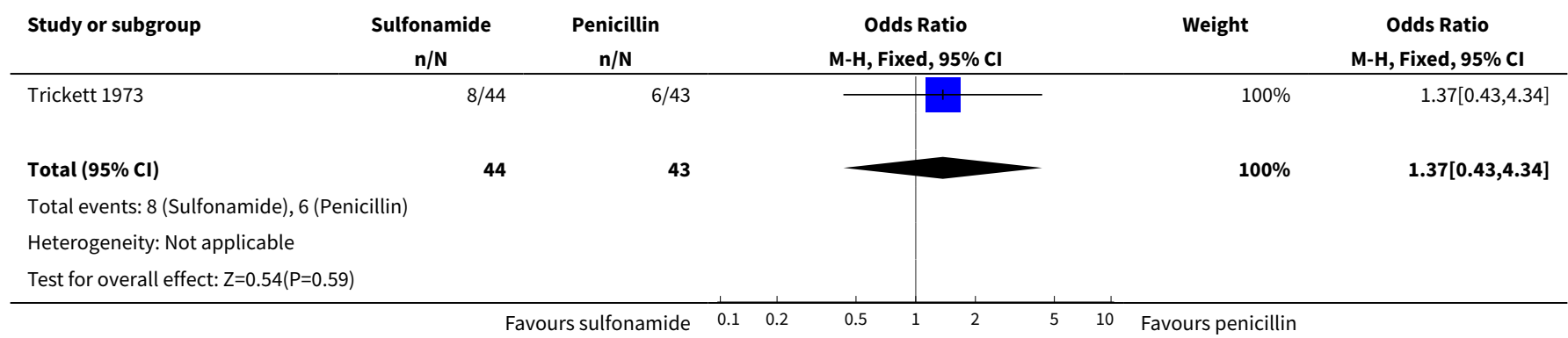

\section{APPENDICES}

\section{Appendix 1. Previous searches}

Our 2012 review update used the search strategy described below. We searched the Cochrane Central Register of Controlled Trials (CENTRAL) 2012, Issue 10, part of The Cochrane Library, www.thecochranelibrary.com (accessed 19 October 2012), which includes the Acute Respiratory Infections Group's Specialised Register, MEDLINE (1966 to October week 4, 2012), EMBASE (1974 to October 2012) and Web of Science (2010 to October 2012).

In 2010 we searched The Cochrane Library, Cochrane Central Register of Controlled Trials (CENTRAL 2010, Issue 3) which includes the Acute Respiratory Infections Group's Specialised Register, MEDLINE (1966 to July Week 4, 2010) and EMBASE (1974 to August 2010).

The following search strategy was used to search MEDLINE and CENTRAL. The MEDLINE search terms were combined with the Cochrane Highly Sensitive Search Strategy for identifying randomised trials in MEDLINE: sensitivity- and precision-maximising version (2008 revision); Ovid format (Lefebvre 2009). The search terms were adapted for EMBASE (Appendix 3).

\section{MEDLINE (Ovid)}

1 exp Pharyngitis/

2 pharyngit*.tw.

3 Nasopharyngitis/

4 nasopharyngit ${ }^{\star} . t w$.

5 rhinopharyngit ${ }^{\star}$. tw.

6 tonsillit*.tw.

7 tonsillopharyngit ${ }^{\star}$. tw.

8 sore throat*.tw.

9 (strep ${ }^{\star}$ adj3 throat $\left.{ }^{\star}\right)$.tw.

10 Streptococcal Infections/

11 "group a beta hemolytic streptococc*".tw.

12 "group a beta haemolytic streptococc*".tw.

13 gabhs.tw.

14 or/ $10-13$

15 throat $^{\star}$.tw.

1614 and 15

171 or 2 or 3 or 4 or 5 or 7 or 8 or 9 or 16

18 exp Anti-Bacterial Agents/

19 (antibacterial $^{\star}$ or anti bacterial ${ }^{\star}$ ).tw.

20 antibiotic ${ }^{*} . t w$.

21 or $/ 18-20$

2217 and 21

There were no language or publication restrictions. 


\title{
Appendix 2. MEDLINE and CENTRAL search strategy \\ MEDLINE (Ovid)
}

1 exp Pharyngitis/

2 pharyngit ${ }^{\star}$. tw.

3 Nasopharyngitis/

4 nasopharyngit ${ }^{\star}$. tw.

5 rhinopharyngit ${ }^{\star} . t w$.

6 tonsillit*.tw.

7 tonsillopharyngit ${ }^{\star}$.tw.

8 sore throat ${ }^{\star}$. tw.

9 (throat* ${ }^{\star}$ adj3 (infect* or inflam $\left.^{\star}\right)$ ).tw.

10 (strep* adj3 (throat* or pharyng*)).tw.

11 Streptococcal Infections/

12 Streptococcus pyogenes/

13 ("group a" adj5 streptococc*).tw.

14 gabhs.tw.

15 or/11-14

16 (throat* or pharyng $\left.^{\star}\right)$.tw.

1715 and 16

181 or 2 or 3 or 4 or 5 or 7 or 8 or 9 or 10 or 17

19 exp Anti-Bacterial Agents/

20 (antibacterial ${ }^{\star}$ or anti bacterial ${ }^{\star}$ ).tw.

21 antibiotic*.tw.

22 exp beta-lactams/

23 exp aminoglycosides/

24 exp Macrolides/

25 exp Quinolones/

26 exp Sulfonamides/

27 exp Tetracyclines/

28 (aminoglycoside* or amoxicillin* or amoxycillin* or ampicillin* or azithromycin* or benzylpenicillin* or beta-lactam* or betalactam* or cefaclor $^{\star}$ or cefadroxil or cefalexin or cefdinir or cefditoren or cefixime or cefpodoxime or cefprozil or ceftibuten or ceftriaxone or cefuroxime or cephalosporin* or clarithromycin or clavulanic acid ${ }^{\star}$ or clindamycin or co-amoxyclav* or doripenem or doxycycline or eratapenem or erythromycin or imipenem or lincomycin or macrolide* or meropenem or moxifloxacin or penicillin* or phenoxymethylpenicillin* or piperacillin* or quinolone* or roxithromycin $^{\star}$ or sulfamethoxazole ${ }^{\star}$ or sulfonimide ${ }^{\star}$ or tetracycline* or ticarcillin or trimethoprim*).tw,nm. 29 or $/ 19-28$

3018 and 29

The MEDLINE search terms were combined with the Cochrane Highly Sensitive Search Strategy for identifying randomised trials in MEDLINE: sensitivity- and precision-maximising version (2008 revision); Ovid format (Lefebvre 2011)

\section{Appendix 3. Embase.com (Elsevier) search strategy}

\author{
\#31 \#22 AND \#30 \\ \#30 \#25 NOT \#29 \\ \#29 \#26 NOT \#28 \\ \#28 \#26 AND \#27 \\ \#27 'human'/de \\ \#26 'animal'/de OR 'nonhuman'/de OR 'animal experiment'/de
}

\#25 \#23 OR \#24

\#24 random*:ab,ti OR placebo*:ab,ti OR crossover*:ab,ti OR 'cross over':ab,ti OR allocat*:ab,ti OR trial:ti OR (doubl* NEXT/1 blind*):ab,ti

\#23 'randomized controlled trial'/exp OR 'single blind procedure'/exp OR 'double blind procedure'/exp OR 'crossover procedure'/exp

\#22 \#16 AND \#21

\#21 \#17 OR \#18 OR \#19 OR \#20

\#20 aminoglycoside*:ab,ti OR amoxicillin*:ab,ti OR amoxycillin*:ab,ti OR ampicillin*:ab,ti OR azithromycin*:ab,ti OR benzylpenicillin*:ab,ti OR 'beta-lactam':ab,ti OR 'beta-lactams':ab,ti OR betalactam*:ab,ti OR cefaclor*:ab,ti OR cefadroxil:ab,ti OR cefalexin:ab,ti OR cefdinir:ab,ti OR cefditoren:ab,ti OR cefixime:ab,ti OR cefpodoxime:ab,ti OR cefprozil:ab,ti OR ceftibuten:ab,ti OR ceftriaxone:ab,ti OR cefuroxime:ab,ti OR cephalosporin*:ab,ti OR clarithromycin:ab,ti OR 'clavulanic acid':ab,ti OR clindamycin:ab,ti OR 'co-amoxyclav':ab,ti OR doripenem:ab,ti OR doxycycline:ab,ti OR eratapenem:ab,ti OR erythromycin:ab,ti OR imipenem:ab,ti OR lincomycin:ab,ti OR

macrolide*:ab,ti OR meropenem:ab,ti OR moxifloxacin:ab,ti OR penicillin*:ab,ti OR phenoxymethylpenicillin*:ab,ti OR piperacillin*:ab,ti OR quinolone*:ab,ti OR roxithromycin*:ab,ti OR sulfamethoxazole*:ab,ti OR

sulfonimide*:ab,ti OR tetracycline*:ab,ti OR ticarcillin:ab,ti OR trimethoprim*:ab,ti 
\#19 'beta lactam antibiotic'/exp OR 'aminoglycoside antibiotic agent'/exp OR 'macrolide'/exp OR 'quinolone derivative'/exp OR 'sulfonamide'/exp OR 'tetracycline derivative'/exp

\#18 antibiotic*:ab,ti OR antibacterial*:ab,ti OR 'anti-bacterial':ab,ti OR 'anti-bacterials':ab,ti

$\# 17$ 'antibiotic agent'/exp

\#16 \#1 OR \#2 OR \#3 OR \#4 OR \#5 OR \#6 OR \#7 OR \#15

\#15 \#13 AND \#14

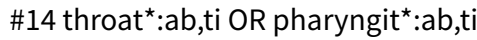

\#13 \#9 OR \#10 OR \#11 OR \#12

\#12 gabhs:ab,ti

\#11 ('group a' NEXT/5 streptococc*):ab,ti

$\# 10$ 'streptococcus pyogenes'/de

\#9 'streptococcus infection'/de OR 'group a streptococcal infection'/de

\#8 ( strep* NEAR/3 (throat $^{\star}$ OR pharyngit*)):ab,ti

\#7 'streptococcal pharyngitis'/de

\#6 'sore throat':ab,ti OR 'sore throats':ab,ti OR (throat* NEAR/3 (infect* OR inflam)):ab,ti

\#5 'sore throat'/de

\#4 tonsillit*:ab,ti OR tonsillopharyngit*:ab,ti

\#3 'tonsillitis'/de

\#2 pharyngit*:ab,ti OR nasopharyngit*:ab,ti OR rhinopharyngit*:ab,ti

\#1 'pharyngitis'/de OR 'rhinopharyngitis'/de OR 'viral pharyngitis'/de

\section{Appendix 4. Web of Science (Thomson Reuters) search strategy}

\begin{tabular}{|l|l|}
\hline$\# 6$ & 18 \\
\hline$\# 5$ & 297 \\
\hline$\# 4$ & \\
\hline$\# 4$ \\
\hline$\# 3$ & $1,296,034$ \\
\hline & 1,398 \\
\hline$\# 2$ & \\
\hline & \\
\hline$\# 1$ & 2,840 \\
\hline
\end{tabular}

WHAT'S NEW

\begin{tabular}{lll}
\hline Date & Event & Description \\
\hline 25 March 2016 New search has been performed & $\begin{array}{l}\text { We updated the searches and identified two new studies. We ex- } \\
\text { cluded one of the studies (Stillerman 1970). Further details have } \\
\text { been requested from the authors of the other identified study } \\
\text { (Eslami 2014), which is currently inserted in the 'Studies awaiting } \\
\text { classification' section. }\end{array}$ \\
\hline
\end{tabular}




\begin{tabular}{lll}
\hline Date & Event & Description \\
\hline 25 March 2016 & $\begin{array}{l}\text { New citation required but conclusions } \\
\text { have not changed }\end{array}$ & The review conclusions remain unchanged. \\
\hline
\end{tabular}

\section{HISTORY}

Protocol first published: Issue 3, 2003

Review first published: Issue 10, 2010

\begin{tabular}{|c|c|c|}
\hline Date & Event & Description \\
\hline 5 December 2014 & New search has been performed & $\begin{array}{l}\text { This review update includes the Pfizer } 2011 \text { study that was iden- } \\
\text { tified in the } 2013 \text { review publication and had been awaiting clas- } \\
\text { sification until data became available. We did not identify any } \\
\text { new studies for inclusion in the } 2014 \text { updated search. We identi- } \\
\text { fied three new trials for exclusion (Kuroki 2013; Stelter 2014; Van } \\
\text { Brusselen 2014). The review conclusions remain unchanged. }\end{array}$ \\
\hline 5 December 2014 & $\begin{array}{l}\text { New citation required but conclusions } \\
\text { have not changed }\end{array}$ & $\begin{array}{l}\text { Our conclusions remain unchanged. In this update we added a } \\
\text { 'Summary of findings' tables and integrated GRADE assessment } \\
\text { into the text of the review. }\end{array}$ \\
\hline 19 October 2012 & New search has been performed & $\begin{array}{l}\text { The updated searches identified five new references. Four } \\
\text { studies were excluded (Bottaro 2012; Cruz 2011; Rimoin 2011; } \\
\text { NCT00393744), and we requested results from one completed } \\
\text { unpublished study (NCT00643149). }\end{array}$ \\
\hline 19 October 2012 & $\begin{array}{l}\text { New citation required but conclusions } \\
\text { have not changed }\end{array}$ & Our conclusions remain unchanged. \\
\hline 6 October 2010 & Amended & Contact details updated. \\
\hline 31 August 2008 & Amended & Converted to new review format. \\
\hline
\end{tabular}

\section{CONTRIBUTIONS OF AUTHORS}

MVD wrote the protocol. All authors contributed to final editing of the protocol.

ST conducted the searches for this review.

MVD and NK selected trials for the original version of the review. MVD and ADS reviewed searches for the subsequent updates.

$\mathrm{HH}$ assisted with the selection process.

MVD, ADS, and NK independently performed quality assessment.

MVD and NK performed data extraction with support from ADS. MVD analysed the data.

MVD wrote the draft review and addressed the reviewers' comments. MVD updated the review.

All review authors contributed to the discussion and the editing.

\section{DECLARATIONS OF INTEREST}

Mieke L van Driel: None known.

An IM De Sutter: None known. 
Hilde Habraken: None known.

Sarah Thorning: None known.

Thierry Christiaens: None known

\section{SOURCES OF SUPPORT}

\section{Internal sources}

- None received, Other.

\section{External sources}

- None received, Other.

\section{DIFFERENCES BETWEEN PROTOCOL AND REVIEW}

In the 2010 review, outcomes were split into primary and secondary. The composite outcome 'resolution of symptoms' was included as a primary outcome.

In the 2014 update, the risk of bias assessment tool was changed from the Jadad score to the Cochrane risk of bias assessment tool. We also included a GRADE assessment using the GRADEPro software and added a description of the GRADE assessment of the overall quality of the evidence to the methods section and text of the review.

Following advice from the Statistical Editor, we changed the analysis method for pooling to a random-effects model as the default. To be consistent with our protocol (van Driel 2003), we also used a fixed-effect model if there was no substantial heterogeneity, and compared results in a sensitivity analysis. This was mentioned as a sensitivity analysis in the protocol (van Driel 2003) and is now described in the Methods section as a subgroup analysis.

We performed subgroup analyses for adults and children where appropriate because this is relevant to clinicians; this was added to the Methods section.

Sensitivity analysis: Our protocol planned sensitivity analyses for patients in different settings, per carrier status, or diagnostic criteria (throat culture or rapid test), publication status (published versus unpublished studies, studies published as abstract versus full text articles, year of publication). These were replaced with sensitivity analysis of the impact of heterogeneity and of applying a random-effects and fixed-effect model.

Sensitivity analysis according to methodological quality rated on the Jadad score (van Driel 2003) was abandoned with the introduction of the Cochrane risk of bias assessment.

The 2016 author team was changed to include Sarah Thorning as an author. Natalja Keber no longer contributed to the review and was removed as an author.

The outcome 'incidence of relapse' was added to the Summary of findings table for cephalosporins compared to penicillin.

\section{N DEX TERMS}

\section{Medical Subject Headings (MeSH)}

*Streptococcus pyogenes; Ampicillin [therapeutic use]; Anti-Bacterial Agents [*therapeutic use]; Cephalosporins [therapeutic use]; Clindamycin [therapeutic use]; Macrolides [therapeutic use]; Penicillins [therapeutic use]; Pharyngitis [ ${ }^{\star}$ drug therapy] [microbiology]; Randomized Controlled Trials as Topic; Streptococcal Infections [ ${ }^{\star}$ drug therapy] [microbiology]; Sulfonamides [therapeutic use]

\section{MeSH check words}

Adult; Child; Humans 